\title{
Structural Geology and
}

\section{Volcanism of Owens Valley}

Region, California-

A Geophysical Study

GEOLOGIGAL SURVEY PROFESSIONAL PAPER 438

Prepared partly in cooperation with

the California Division of Mines and Geology

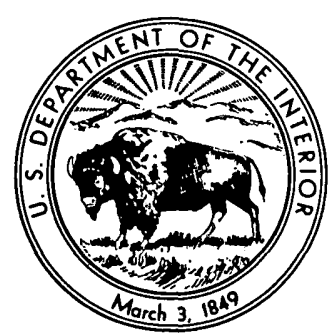




\section{Structural Geology and}

Volcanism of Owens Valley

Region, California-

A Geophysical Study

By L. C. PAKISER, M. F. KANE, and W. H. JACKSON

GEOLOGICAL SURVEY PROFESIONAL PAPER 438

Prepared partly in cooperation with

the California Division of Mines and Geology

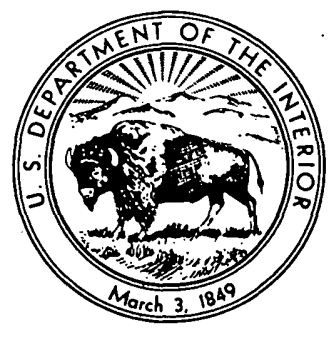

UNITED STATES GOVERNMENT PRINTING OFFICE, WASHINGTON : 1964 


\title{
UNITED STATES DEPARTMENT OF THE INTERIOR
}

\author{
STEWART L. UDALL, Secretary
}

\section{GEOLOGIGAL SURVEY}

\author{
Thomas B. Nolan, Director
}

The U.S. Geological Survey Library has cataloged this publication as follows :

\section{Pakiser, Louis Charles}

1919-

Structural geology and volcanism of Owens Valley region, California ; a geophysical study, by L. C. Pakiser, M. F. Kane, and W. H. Jackson. Washington, U.S. Govt. Print. Off., 1964.

iv, 67 p. maps (2 col.) "diagrs., profiles, table." (U.S. Geological Survey. Professional paper 438)

Part of illustrative matter fold. in pocket.

Prepared partly in cooperation with the California Division of Mines. Bibliography : p. 63-65.

(Continued on next card)

Pakiser, Louis Charles 1919- Structural geology and volcanism of Owens Valley region, California. 1964. (Card 2)

1. Geology-California-Owens Valley. 2. Gravity. 3. Magnetism, Terrestrial-California-Owens Valley. I. Kane, Martin Francis 1928- joint author. II. Jackson, Wayne Harold 1919joint author. III. California. Division of Mines. IV. Title. (Series) 


\section{CONTENTS}

Abstract....

Introduction.............

Purpose of study

Previous geophysical studies.....................

Fieldwork and acknowledgments................

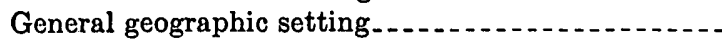

Climate and vegetation

Economic development. . . . . . . . . . . . . . .

Geology

Pre-Tertiary rocks

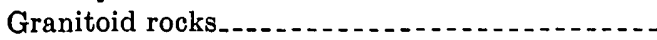

Sedimentary rocks of the White and Inyo

Mountains

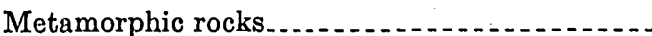

Cenozoic rocks................

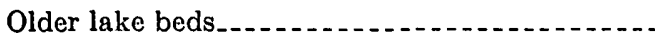

Younger lake beds..................

Alluvial fans

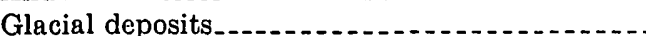

Volcanic rocks north of Bishop................

Volcanic rocks of Tertiary(?) age

Volcanic rocks of Pleistocene age............

Volcanic rocks of Owens Valley............

Structure and physiography

Older structural framework..................

Basin and range structural features...........

Volcano-tectonic features......................

Evolution of the present land forms........

Physiographic evidence.................

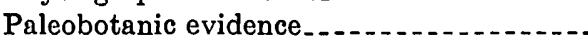

Geophysical surveys

Gravity survey

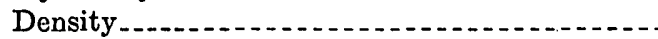

Fieldwork and computations.................

Accuracy of data...............

Interpretation of gravity data............

Gravity contour maps.....................

Area north of Owens Valley.........

Northern Owens Valley..............

Central Owens Valley.................

Owens Lake basin

Gravity effects of dense pre-Tertiary rocks.-

Regional gravity and isostatic compensation

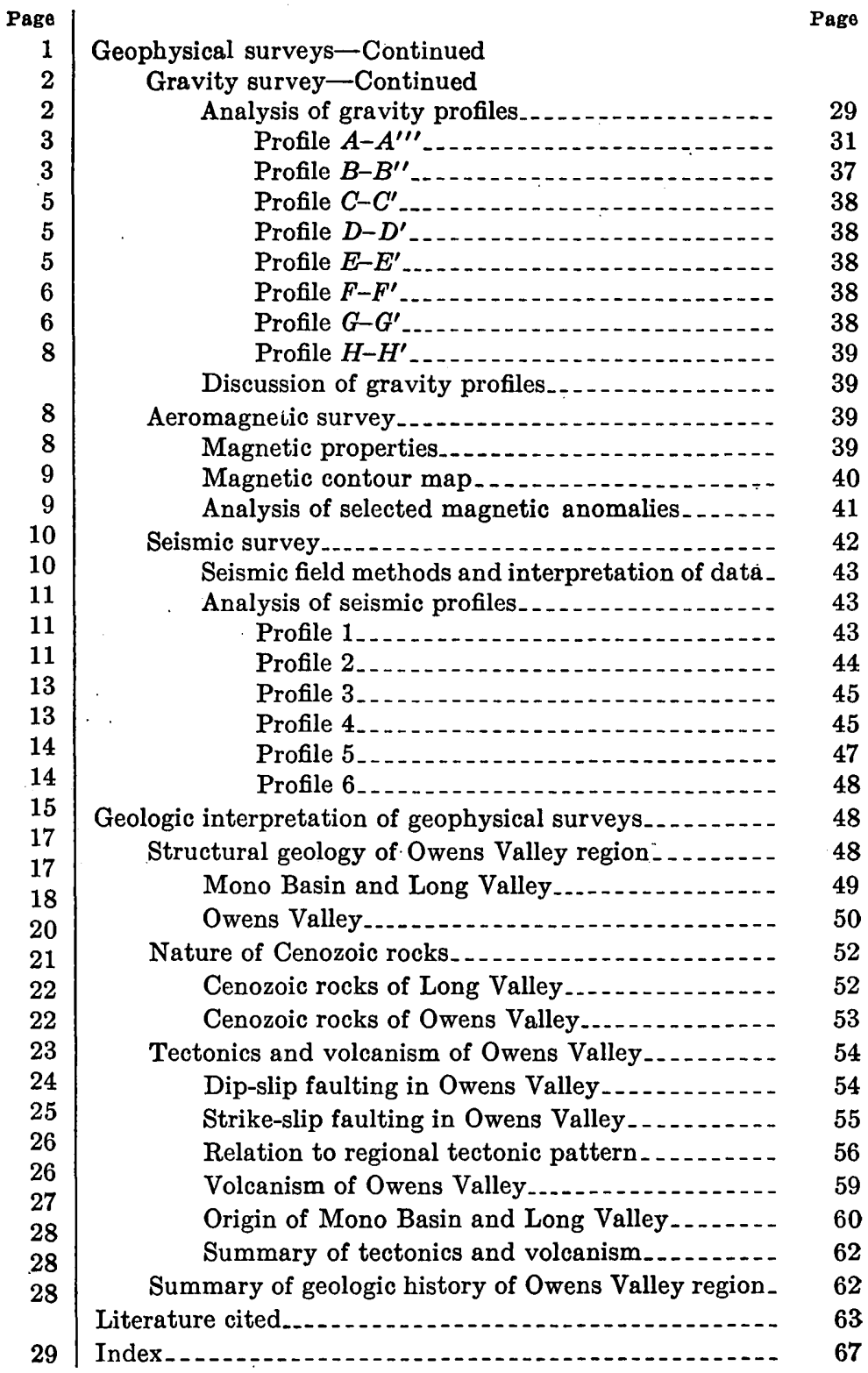

\section{ILLUSTRATIONS}

[Plates are in pocket]

Plate 1. Combined gravity and geologic map, showing location of seismic profiles, of:

Sheet 1. Area north of Owens Valley.

Sheet 2. Northern Owens Valley.

Sheet 3. Central Owens Valley and Owens Lake basin. 
l'uAte 2. Combined aeromagnetic, gravity, and geologic map of an area including parts of Long Valley, Volcanic tableland, and Owens Valley.

3. Analyses of seismic profiles 2, 4, 5, and 6, Owens Valley region.

FIGURe 1. Map showing geographic setting and gravity coverage

2. Generalized geologic map.

3-4. Cross sections showing:

3. Erosion surface of Kern County-Mount Whitney area

4. Erosion surfaces of Yosemite Valley area...

5. Histograms of gravity data

6-7. Diagrams showing analyses of gravity profiles across:

6. Eastern Long Valley

8-9. Gravity profiles across:

8. Long Valley and northern extension of Owens Valley

9. Mono Basin and Long Valley

10-15. Diagrams showing analyses of gravity profiles:

10. In Mono Basin

11. From Mount Humphreys to Deep Spring Valley

12. Near Big Pine.

13. North of Tungsten Hills.

14. East of Mount Whitney

15. In Owens Lake basin

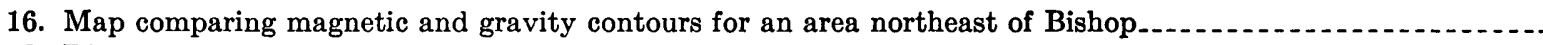
17-18. Diagrams showing analyses of seismic profiles:

17. Southeast of Owens Lake.

18. South of Lone Pine

19-20. Maps showing:

19. Fault pattern and volcanic rocks....

20. Regional geology of southern California and southwestern Nevada

TABLE 


\title{
STRUGTURAL GEOLOGY AND VOLGANISM OF OWENS VALLEY REGION CALIFORNIA-A GEOPHYSICAL STUDY
}

\author{
By L. C. PAkISER, M. F. KANe, and W. H. JACkson
}

\begin{abstract}
Owens Valley in eastern California is one of the westernmost downdropped blocks of the Basin and Range province and is important because it includes part of the boundary between the Sierra Nevada and Great Basin regions. As described in this report, the Owens Valley region includes Owens Valley, Long Valley, Mono Basin, and the slopes of the Sierra Nevada and the White and Inyo Mountains. Several small basin ranges are included in the northern part of the region. Owens Valley is terminated on the south by the Coso Range.

A regional geophysical study of the Owens Valley region was made to determine as completely as possible the Cenozoic structural geology and to deduce from the structural features thus described a possible explanation for the geologic processes that brought them into existence. Gravity and seismic-refraction measurements were made to determine the configuration of the interface between the Cenozoic deposits and pre-Tertiary rocks; this determination is possible because of a marked discontinuity in density and seismic velocity at the interface. An aeromagnetic survey was made of part of the region to determine the distribution of some of the volcanic rocks of Cenozoic age that are associated with Cenozoic structural features; this determination is possible because the more mafic of these volcanic rocks are more magnetic than other Cenozoic deposits. Differences in density and magnetization within the pre-Tertiary rocks also provide some information on older features. Fieldwork was started in 1954 and completed in 1958.
\end{abstract}

The pre-Tertiary rocks of the Owens Valley region include the granitoid and the metasedimentary and metavolcanic rocks that predominate in the Sierra Nevada and the sedimentary rocks that predominate in the White and Inyo Mountains. These rocks range in age from Precambrian to Cretaceous. Clastic deposits of Cenozoic age include the lake beds and stream deposits of Owens Valley, Long Valley, and Mono Basin, the Pleistocene moraines of the Sierra Nevada slopes, and the alluvial fans of the Sierra Nevada, White and Inyo Mountains' fronts. Volcanic rocks of late Tertiary(?) and Pleistocene ages are widespread throughout the Owens Valley region; they are especially abundant in the embayment of the Sierra Nevada front that includes Long Valley and Mono Basin. These Cenozoic volcanic rocks range in composition from basalt to rhyolite and in age from early Pliocene (?) to latest Pleistocene.

The faults that bound the main Cenozoic structural features of the Owens Valley region may have been inherited from earlier zones of weakness that were brought into existence perhaps during the Nevadan orogeny of the late Mesozoic. Owens Valley is a downdropped block, or graben, between the Sierra Nevada and the White and Inyo Mountains. The physiographic expression of the near-linear western front of the White and Inyo Mountains is remarkably simple in form. The physiography of the eastern front of the Sierra Nevada is much more irregular and complex and is the expression of some warping as well as block faulting. The association of volcanic rocks with the depressions of Long Valley and Mono Basin suggests that these structural features may have been created in part by volcano-tectonic processes.

Physiographic evidence from observations of the streams of the Sierra Nevada and fossil flora have been used by different investigators to deduce conflicting versions of the history of uplift of the Sierra Nevada and the Cenozoic deformation along its eastern front. Two periods of Cenozoic uplift have been deduced on the basis of the erosion surfaces of the Kern, Merced, and other rivers of the southern Sierra Nevada by Lawson, Knopf, and Matthes ; late Tertiary fossil plants have led Axelrod to the conclusion that only one important uplift occurred-at the end of the Tertiary and in early Pleistocene time.

The contrast in density between the Cenozoic deposits of Owens Valley, Long Valley, and Mono Basin and the pre-Tertiary rocks that confine these deposits is about $-0.4 \mathrm{~g}$ per $\mathrm{cm}^{3}$. Therefore, thick accumulations of Cenozoic deposits are expressed as gravity lows, and where the contacts between these deposits and the older rocks are steep, the gravity gradients along these contacts are large. Measurements of gravity show Owens Valley to be expressed by an elongated gravity low having a residual gravity relief of $30-40 \mathrm{mgals}$ (milligals). The gravity gradients along the eastern boundary of Owens Valley are steep and nearly linear; only one important discontinuity occurs. The gravity gradients along the Sierra Nevada front of Owens Valley are discontinuous and alternate between steep and gentle. Detailed interpretation of several gravity profiles across Owens Valley shows that a steeply dipping fault forms a common boundary between the Owens Valley depression and the White and Inyo Mountains chain. The west fault bounding the deepest wedge of Owens Valley is in general east of the Sierra Nevada front, and the deformation alternates between faulting and warping along the valley trend. The maximum thickness of Cenozoic deposits in Owens Valley is $8,000 \pm 2,000$ feet.

Long Valley is expressed by a large, elliptical gravity low, flanked by extremely large gradients, that has a residual gravity relief of more than 60 mgals. Detailed interpretation of the anomaly shows that Long Valley subsided along near-vertical faults and received an accumulation of about $18,000 \pm 5,000$ feet of low-density sediments and volcanic deposits of Cenozoic age. Mono Basin is a structural basin of the same type. Many smaller Cenozoic structural features are revealed by gravity anomalies.

Interpretation of the aeromagnetic data from the northern bart of the Owens Valley region reveals the probable existence 
of a large amount of volcanic material buried near the center of Long Valley and also in Owens Valley northeast of Bishop. A pile of volcanic material probably also lies buried near the center of Mono Basin.

Interpretation of six long seismic-refraction profiles in Owens Valley and Long Valley yields depths to pre-Tertiary rocks and velocity boundaries within the Cenozoic section that are consistent with those obtained from the gravity interpretation and thus greatly narrows the range of uncertainty concerning the thickness of Cenozoic deposits.

A study of the volume of the deposits of Cenozoic age in Long Valley and Mono Basin that could have been transported from pre-Tertiary rock sources to these structural basins by streams compared with the combined volume of these features indicates that about two-thirds of the Cenozoic deposits are probably of volcanic origin. The Cenozoic deposits of Owens Valley are predominantly stream-transported clastic sediments.

Strike-slip movement is known to have taken place along the main faults of Owens Valley, but the direction of movement is in doubt. A detailed analysis of the published record of the Owens Valley earthquake of 1872, examination of the area, and analysis of the distribution of the volcanic fieIds of Owens Valley leads to the conclusion that the predominant direction of horizontal movement has probably been left lateral. This conclusion is compatible with the directions of motion for the San Andreas, Garlock, and White Wolf faults, and the Walker Lane zone of faulting.

The basalt flows of Owens Valley and the southern Inyo Mountains were erupted from sources in regions of relative tension or stress relief near the ends of important transcurrent faults if the direction of horizontal movement was left lateral (that is, if Owens Valley is a great left-lateral shear zone). This interpretation suggests that the Sierra Nevada has been moving south with respect to Owens Valley and the Great Basin region to the east. If this is so, the embayment in the Sierra Nevada front that contains Long Valley and Mono Basin would tend to be stretched or pulled apart. Regions of low pressure, such as that inferred to exist in the Long Valley-Mono Basin area, would be favorable to the generation of magma by the reduction of stress and possible inward migration of water and other volatiles from surrounding regions of higher pressure; thus, the melting point of the rock materials would be reduced. Reduction of the confining pressure of the rocks over a magma chamber thus created would encourage volcanic eruption. A leory relating the tectonics and volcanism of the Owens Valley egion based on these principles is proposed. It leads to the conclusion that Mono Basin and Long Valley are volcano-tectonic depressions that subsided in response to volcanic eruptions as support was removed from a magma chamber at depth.

After the emplacement of the Sierra Nevada batholith in Late Cretaceous time, the Sierra Nevada was a low mountain range, perhaps no more than 3,000 feet above sea level. Then, in a series of uplifts, it was raised to its present great heights. The most important of these uplifts probably took place in late Miocene or early Pliocene times and again at the end of the Tertiary and beginning of the Pleistocene. These two major uplifts were separated by a period of quiescence. Extensive faulting in the Owens Valley region took place probably during these major uplifts, but the deepest wedge of Owens Valley may have begun to subside and to receive sediments at some earlier time. Long Valley and Mono Basin probably began to subside concurrently with the early Pliocene(?) volcanic eruptions in the area, and subsidence probably ended with the latest eruptions from Mono Craters. Glaciers in
Pleistocene time sculptured the slopes of the Sierra Nevada in the Owens Valley region and deposited moraines. Finally, recent stream action modified Owens Valley to form the present landscape.

\section{INTRODUCTION}

\section{PURPOSE OF STUDY}

Owens Valley is one of the most conspicuous physiographic and geologic boundary features in the United States, as well as a geologic feature of intrinsic interest. It is one of the westernmost of the downdropped blocks of the Basin and Range province. On the west, the crest of the Sierra Nevada separates the Sierra Nevada Mountains from the Great Basin region to the east.

From the time of the earliest geologic studies in this area (Whitney, 1865, p. 456; Gilbert, 1875; King, 1878; Russell, 1887) Owens Valley has been described as a downdropped fault block. This conclusion, however, remains open to doubt because it has been based largely on physiographic evidence that, powerful though it may be, is not conclusive. Knopf (1918, p. 78), in his study of the Owens Valley area, stated that the evidence of faulting along the Sierra Nevada escarpment

consists in the sharply descending slope, the topographic discontinuity, the orersteepening toward the foot of the escarpment, and the dislocation of gravel-filled channels and their overlying lavas. In addition, triangular faceting of the mountain spurs, another evidence of faulting *** has been recognized along the west wall of Owens Valley in extraordinarily impressive development.

Recent detailed geologic mapping by P. C. Bateman (written commun., 1958) and J. G. Moore (written commun., 1958) provided additional physiographic and geologic evidence of faulting.

The evidence for faulting along most of the western front of the White and Inyo Mountains is less impressive than that for the eastern front of the Sierra Nevada, except for the remarkably near-linear trend of this front throughout its length. At best, the evidence for faulting from surface geologic mapping alone is fragmental and permits only broad speculation on the major structural trends and the magnitude of fault deformation. Many important faults are entirely concealed by surficial debris and remained unknown until the geophysical study was undertaken.

The clastic rocks that fill the Owens Valley block and other similar features in the Great Basin and that have been derived to a large extent from erosion of the surrounding mountains are considerably less dense than the older rocks that confine them. Therefore, thick sequences of such lighter, younger rocks should be revealed by pronounced gravity minimums. Fairly detailed gravity measurements are expected to give reliable information on the approximate depth and con- 
figuration of the surface of denser, older rocks that lies buried beneath the valley fill. Faults having vertical displacement and other structural features of great vertical relief that have formed during and after deposition of the valley fill should be clearly revealed by gravity measurements. . In brief, gravity surveying provides a rapid and economic geophysical method of studying the structural geology of areas such as Owens Valley. Results of aeromagnetic surveying yield valuable clues on volcanic and other igneous features buried under valley fill because these igneous rocks are generally more magnetic than the clastic rocks that surround or overlie them. Seismic-refraction measurements provide reliable information on the depth to the older rocks of higher seismic velocity, as well as depths to layers within the valley fill.

'This study, therefore, was undertaken to obtain as much information as possible on the structural geology of Owens Valley and its relations to surrounding geologic features and to the geologic history of the Sierra Nevada and the Great Basin regions. Oliver (1956) is engaged in a related but broader gravity study of the crustal structure in the Sierra Nevada region. Mabey (1958) is studying the Death Valley region to the east.

\section{PREVIOUS GEOPHYSICAL STUDIES}

Gutenberg, Wood, and Buwalda (1932) made a series of seismic experiments in Owens Valley at Diaz Lake, east of Alabama Hills, and near the Sierra Nevada frontal fault near Independence in the summer of 1931. They reported that the Diaz Lake beds are $\mathbf{1 1 0}$ meters thick 46 meters east of the base of Alabama Hills and more than 100 meters thick 200 meters east of the base of the hills; bedrock was not found at a location 400 meters farther to the east. These data suggest that the fault bounding Alabama Hills dips $60^{\circ}$ or more eastward. The thickness of the Diaz Lake beds was determined from shallow reflections 23 years before the shallow seismic-reflection method was first studied in detail (Pakiser and others, 1954). About 8 miles southwest of Independence, along the east side of the main Sierra Nevada fault, Gutenberg, Wood, and Buwalda obtained refractions from the fault surface by using a geophone spread close to the fault and three shot points at different distances from the fault. The thickness of the alluvium at this location was not determined, but it is greater than 250 meters.

In the summers of 1952 and 1953, H. W. Oliver (written commun., 1957) made gravity measurements in the Bishop and Lone Pine areas in conjunction with a regional gravity survey of the Sierra Nevada. These measurements revealed that the valley block is expressed by a pronounced gravity low.
FIELDWORK AND ACKNOWLEDGMENTS

Gravity measurements were made during parts of each year from 1954 to 1957 to provide a fairly detailed regional gravity network of the entire modern drainage basin of Owens River from its headwaters at Deadman Creek in the Sierra Nevada to Owens Lake more than 100 miles south and from the eastern scarp of the Sierra Nevada to the western slopes of the White and Inyo Mountains. Additional information was obtained in surrounding areas, including Mono Basin to the north (Pakiser and others, 1960). In all, about 1,600 gravity stations were established in an area of about 4,000 square miles (fig. 1). Kane supervised gravity fieldwork done in February 1954 and the spring of 1956. Pakiser was in charge of the fieldwork done in the summers of $1955-57$.

An aeromagnetic survey was made in the Volcanic Tableland, Long Valley, and Mono Basin in August 1956. A small, detailed survey in an area northeast of Bishop was made in 1957 . The aeromagnetic work was supervised by J. R. Henderson of the Geological Survey.

During the summers of 1957 and 1958, seismic-refraction measurements were made in a cooperative field program of the Seismological Laboratory, California Institute of Technology, and the U.S. Geological Survey. Jackson was in charge of the Geological Survey field party.

We are indebted to R. E. Warrick, who made some of the seismic measurements; Donald Plouff and S. W. Stewart, who made some of the gravity measurements; W. T. Kinoshita, who did some of the planetable and alidade surveying; W. J. Dempsey and J. R. Henderson, who arranged and carried out the aeromagnetic survey; Isidore Zietz, who provided valuable assistance and advice on interpretation of the aeromagnetic data; P. C. Bateman, J. G. Moore, C. D. Rinehart, and D. C. Ross, who provided valuable geologic information and advice and assistance in surveying; and Howard Oliver, who made available gravity data from his study of the Sierra Nevada. All these men are members of the Geological Survey. We acknowledge the generous assistance of S. L. Paratt of the City of Los Angeles Department of Water and Power, who made available detailed maps and bench-mark data along the Los Angeles Aqueduct and arranged for permission to do seismic shooting. We appreciate the support of the State of California Division of Mines, with whose cooperation the work in Long Valley was done. Finally, we are indebted to Dr. Frank Press, Director, Seismological Laboratory, California Institute of Technology, for permission to publish seismic data obtained by that organization, and to John H. Healy, who supervised the fieldwork and 


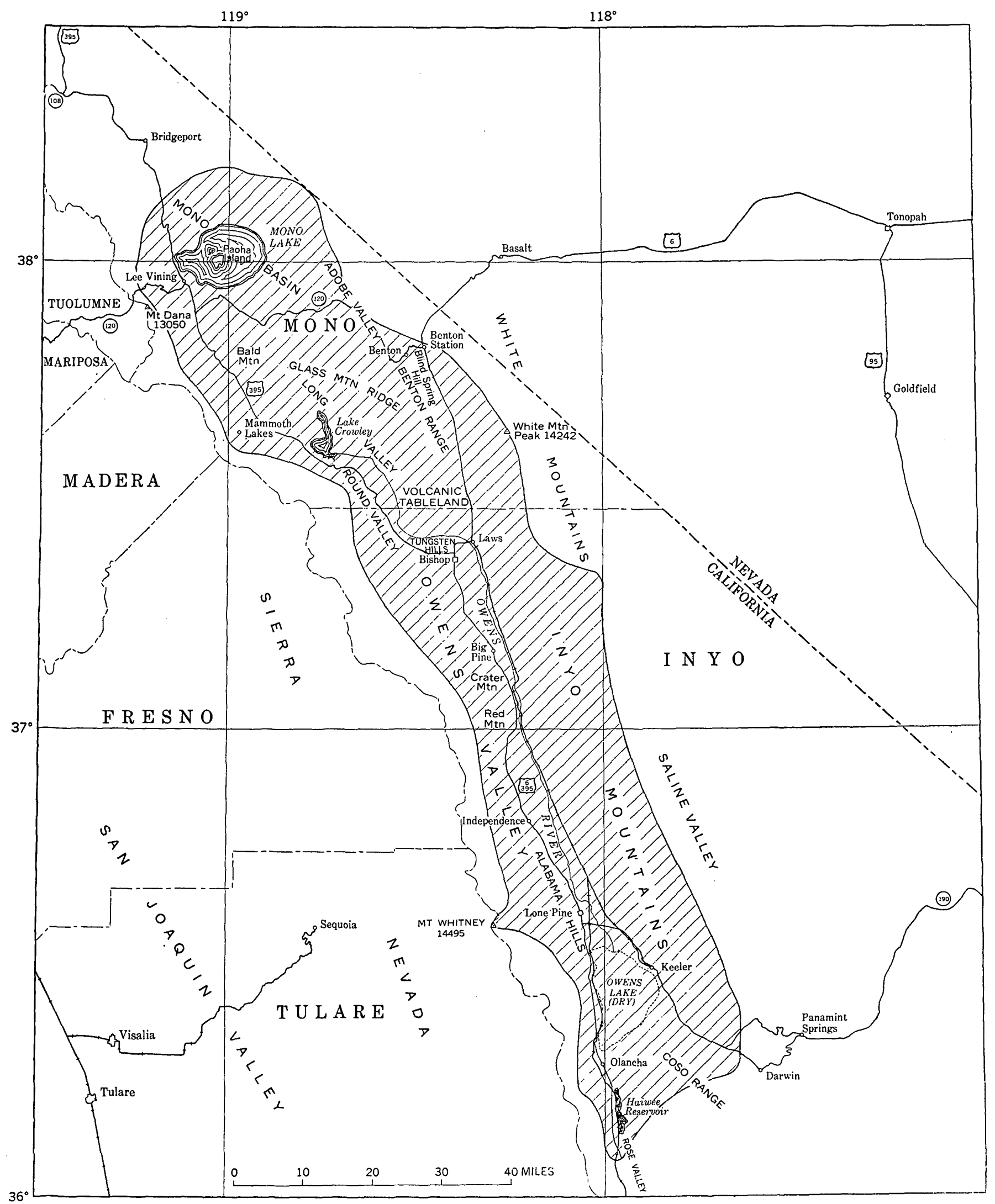

Figure 1.--General geographic setting of the Owens Valley region, showing area of gravity coverage. 
interpreted the data obtained by the Seismological Laboratory field party.

All the manuscript except the sections on gravity fieldwork and computations, the sections on the accuracy of gravity data, the list on principal facts about base stations, and the sections on the seismic survey was written by Pakiser. Kane wrote the sections on the gravity work, and Jackson wrote the sections on the seismic survey. Kane participated in much of the analysis of the gravity data, and Jackson participated in interpretation of the seismic data and in preparation of the final manuscript. The geologic interpretation beginning on page 48 was written by Pakiser.

\section{GENERAI GEOGRAPHIC SETTING}

The Owens Valley area as described in this study includes the Y-shaped area between the crests of the Sierra Nevada and of the White and Inyo Mountains and extends from Glass Mountain Ridge to the south end of Owens Lake (fig. 1). It includes parts of Inyo and Mono Counties, Calif. Mono Basin is immediately to the north of the Owens Valley area, and Rose Valley is immediately to the south. Owens Valley terminates on the southeast against the Coso Range. The area includes the entire modern drainage basin of Owens River, which rises in the Sierra Nevada northwest of Long Valley, is fed by various tributaries from the Sierra Nevada, and empties into Owens Lake. The Owens Valley area includes as well the intermittent drainage system that flows south along the western front of the White Mountains from a point north of Benton Station (fig. 1) into Owens River near Laws. Thus defined, the Owens Valley area includes not only Owens Valley proper, which is a narrow trough extending from the Volcanic Tableland to Owens Lake, but also Round Valley, which is a branch of Owens Valley northwest of Bishop, Long Valley, which is the depressed area that contains Lake Crowley, and the extension of the Owens Valley trough north of Laws along the White Mountains front. 'The Benton Range, several related mountain structures, and the Volcanic Tableland north of Bishop are also included in the Owens Valley area.

The Owens Valley area is an area of great topographic relief, ranging in altitude from about 3,600 feet above mean sea level at Owens Lake to more than 14,000 feet in the Sierra Nevada and the White Mountains. The area is about 120 miles long as measured from Glass Mountain Ridge in the north to the south end of Owens Lake and ranges in width (crest to crest) from 40 miles at the north end to 25 miles at Owens Lake. The minimum width of Owens Valley between Bishop and Big Pine is 15 miles. The total area of the Owens River drainage basin is about 3,300 square miles.
U.S. Highway 395 traverses the entire eastern front of the Sierra Nevada throughout the length of the Owens Valley area. U.S. Highway 6 follows the western front of the northern White Mountains southward and joins Highway 395 at Bishop. California State Highway 190 enters Owens Valley from the east at Lone Pine. The Owens Valley area is served by the Southern Pacific Railroad. The larger towns in Owens Valley include Bishop (having a 1950 population of 2,891), Big Pine (556), Independence (875), and Lone Pine $(1,415)$.

\section{CLIMATE AND VEGETATION}

Temperatures in Owens Valley are extreme and range from hot (often more than $100^{\circ} \mathrm{F}$ ) in the summer to very cold (less than $0^{\circ} \mathrm{F}$ ) in the winter. Cool temperatures prevail throughout the summer on the higher slopes of the Sierra Nevada, however. The climate of Owens Valley and the Great Basin area to the east is arid. The climate of the Sierra Nevada is subhumid, and extensive snowfields form there during the cold winter months and remain through the summer.

Descending the slopes from the crest of the Sierra Nevada eastward, one notices that the vegetation changes from a coniferous forest to a zone of pinyon and juniper pine at about 8,000 feet of altitude and gradually gives way to sagebrush at altitudes of 5,000 or 6,000 feet (Bailey, 1954).

\section{ECONOMIC DEVELOPMENT}

Owens Valley is an area of rich natural resources. Mumford (1954) estimated that Owens Lake Basin contains 160 million tons of various salts, including carbonates, bicarbonates, sulfates, chlorides, and borates of sodium and potassium. Since 1904, five plants have been constructed for the manufacture of soda ash and one for caustic soda. All alkali operations have been discontinued except those at the Columbia Southern Chemical Corp. plant at Bartlett. Altogether, about $1,000,000$ tons of alkali and 30,000 tons of borax have been produced from the brine of Owens Lake.

The Bishop area contains some of the more extensive tungsten deposits of the United States (Bateman and Irwin, 1954; Bateman, 1956). The tungsten minerals that are mined are found in tactite and include scheelite and members of the wolframite group. The Pine Creek mine in the Bishop Tungsten district accounts for about half of the current tungsten production in California, and it contains the largest tungsten reserve in the United States.

Silver, lead, and zinc deposits were mined for a long time at the Cerro Gordo mine east of Lone Pine in the Inyo Mountains and at several smaller mines in the area 
(Carlisle and others, 1954). Small vein deposits of gold have been mined intermittently in the Owens Valley region (Knopf, 1918). Talc, perlite, absorbent clay, and pumice have been produced from several deposits in the Owens Valley area (Wright and others, 1954).

By far the most important resource of Owens Valley is the water of Owens River and its tributaries in the Sierra Nevada, which is supplied to the city of Los Angeles through the Los Angeles Aqueduct.

Agriculture includes cattle grazing on the desert shrubland of Owens Valley, fruit orchards near Bishop, and some production of grain.

Owens Valley is a major resort area, and all the towns serve as headquarters for a variety of summer and winter sports. Fishing, hunting, hiking, and winter sports are the major recreations to which the resort areas cater. The Mammoth Lakes area, on the Sierra Nevada slopes northwest of Bishop overlooking Long Valley, is one of the most highly developed resort areas in California. Many people travel through the Owens Valley area because of its spectacular scenery. As King (1878, p. 742-744) observed:

The two grandest fault-lines shown in the Great Basin are those which define its east and west walls. Whoever has followed the eastern slope of the Sierra from the region of Honey Lake to Owens Valley cannot have failed to observe with wonder the 300 miles of abrupt wall which the Sierra turns to the east.

\section{GEOLOGY}

Owens Valley is a structural trough that has been dropped down as a graben along normal faults that separate it from the Sierra Nevada on the west and from the White and Inyo Mountains on the east (fig. 2). As the valley floor subsided to previously unknown depths below what is now the ground surface, the bounding mountain masses rose. As these mountain blocks rose and as the valley floor subsided, streams and other agents eroded the escarpments forming the valley walls, transported the resultant debris into the valley, and deposited it as alluvial fans, other stream deposits, and lake beds. During much of the time that earth movements along faults were taking place, volcanic vents and fissures poured out large amounts of lava and pyroclastic debris, much of which now lies buried with the valley-fill sediments; however, some of the volcanic material is exposed at the surface. During the ice ages glaciers flowed from the Sierra Nevada into Owens Valley and deposited extensive moraines.

Owens Valley is not a simple tectonic trough, and the main part of Owens Valley is complexly faulted. Long Valley, which lies north and west of the Volcanic Tableland, is structurally separated from Owens Valley by a bedrock barrier, although Owens River flows through both valleys. North of Laws, the Owens Valley trough is uninterrupted along the White Mountains front and terminates near Benton Station. Between the northern White Mountains and the part of the Sierra Nevada escarpment that forms the south and west walls of Long Valley lies a system of low basin ranges, the most prominent of which is the Benton Range. Long Valley is structurally terminated on the north by the Glass Mountain Ridge. Mono Basin is immediately north of Glass Mountain Ridge. Owens Valley is terminated on the south by the Coso Range and by a bedrock ridge that separates Owens Valley from Rose Valley.

The deformation that formed Owens Valley and the surrounding mountain masses may have begun in early Tertiary time. It has continued to very recent times; one of the great earthquakes of Califormia and Nevada occurred on March 26, 1872, as a result of movement along the fault forming the eastern front of Alabama Hills west of Lone Pine (Richter, 1958, p. 499-503). This Tertiary and later deformation was part of the widespread block faulting that gave form to the Basin and Range province.

The only comprehensive report on the geology of the Owens Valley area available in the literature is by Knopf and Kirk (Knopf, 1918), who carried out geologic studies in the White and Inyo Mountains and on the eastern slope of the southern Sierra Nevada in 1912 and 1913. Earlier W. T. Lee (1906) and C. H. Lee (1912) studied and reported briefly on the geology and water resources of Owens Valley. The studies of Knopf and Kirk form the basis for the present study.

The gravity meter "sees" only rocks of contrasting densities; the magnetometer, only rocks of differing magnetic susceptibilities. Fortunately, these are also the rocks that can be studied to distinguish Basin and Range structural features from those of earlier orogenies and Cenozoic volcanic features from the sedimentary rocks that surround them (fig. 2). The contrast in density between the Cenozoic and pre-Tertiary rocks is marked, as is the contrast in magnetic susceptibility between the volcanic and sedimentary rocks of Cenozoic age. There are lesser contrasts in these physical properties between the various pre-Tertiary rocks. The seismic velocity of pre-Tertiary rocks is significantly greater than that of Cenozoic rocks, and important seismic-velocity boundaries occur within the Cenozoic section. The discussion of the rocks of the Owens Valley area that follows is therefore highly generalized and is divided into only two main parts.

\section{PRE-TERTIARY ROCKS}

Comprehensive descriptions of the dense pre-Tertiary rocks of Sierra Nevada and White and Inyo Mountains 


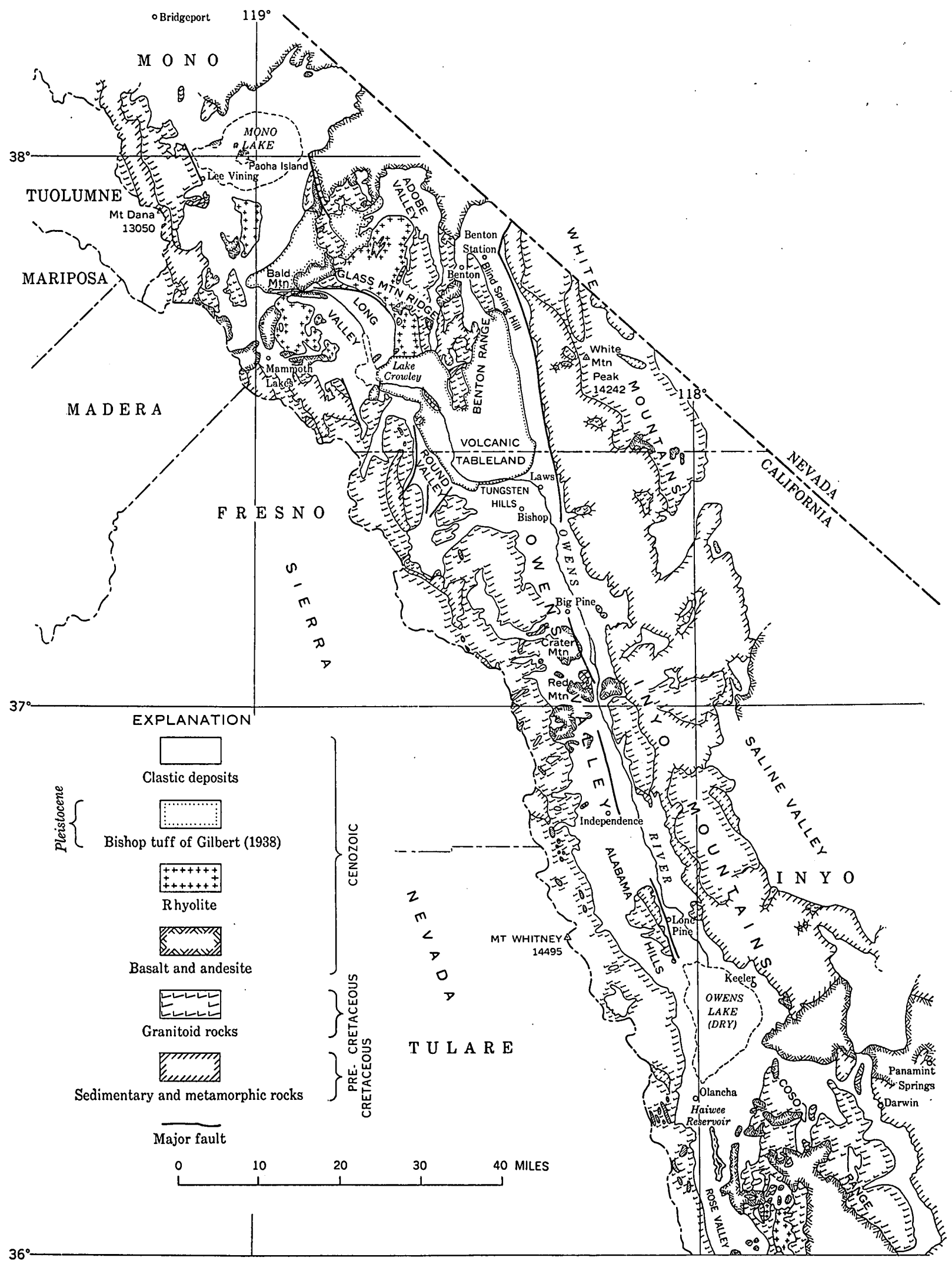

Figure 2.--Generalized geologic map of the Owens Valley region. 
have been written by Knopf and Kirk (Knopf, 1918), by Calkins (in Matthes, 1930), and by Anderson (1937). The rocks of the Sierra Nevada have been described in summary by Mayo (1941). The granitoid rocks of the Sierra Nevada batholith predominate in the Sierra Nevada; sedimentary rocks of Paleozoic age predominate in the White and Inyo Mountains.

\section{GRANITOID ROCKS}

The granodiorite-granite series forms the bulk of the core of the Sierra Nevada batholith and, of this series, quartz monzonite and granodiorite predominate. Siliceous granite and granite porphyry also are present in many places. Hornblende gabbro and hornblende diorite were intruded before the main mass of the batholith was emplaced (Calkins, in Matthes, 1930 ; Mayo, 1941). After the emplacement of the bulk of the core, aplite, pegmatite, and some basic rocks were intruded into the batholithic mass as dikes. The granitoid rocks of the batholith in the eastern Sierra Nevada were divided into seven varieties by Bateman and Merriam (1954). For purposes of the present study it is sufficient to say that most of them are coarse and eugranitic, many are porphyritic, and they range in color from nearly white to very dark, various shades of pink and gray predominating. Many authors considered the Sierra Nevada batholith to be Late Jurassic in age, but recent age studies by the zircon method (Larsen and others, 1954) indicate that these rocks are about 100 million years old, or Late Cretaceous in age. More recently, Curtis, Evernden, and Lipson (1958) showed by the potassiumargon method that the Sierra Nevada batholith near Yosemite National Park ranges in age from 77 to 95 million years and is therefore Late Cretaceous in age.

Anderson (1937) distinguished two units of granitoid rocks in the northern White Mountains; presumably, these are of the same age as the Sierra Nevada batholith.

\section{SEDIMENTARY ROCKS OF THE WHITE AND INYO} MOUNTAINS

The sedimentary rocks of the White and Inyo Mountains have a total thickness of about 36,000 feet and range in age from Precambrian to Triassic. They were described by Kirk (in Knopf, 1918, p. 19-48), who made the first systematic study of these rocks in 1912 and 1913. A brief description of the rocks was compiled recently by Bateman and Merriam (1954) and is summarized in the following paragraphs.

Rocks of Cambrian and Precambrian(?) age include 7,000 feet or more of sandstone and dolomite of Precambrian(?) age, 5,000-6,000 feet of Olenellus-bearing limestone and shale of the Silver Peak group of Early Cambrian age, and $\mathbf{9 0 0}$ feet of limestone, quartzite, and calcareous sandstone of Middle and Late Cambrian age. The formations below the known Olenellus-bearing strata are the Campito sandstone of Early Cambrian age and the Deep Spring formation, the Reed dolomite, and pre-Reed dolomite strata of Precambrian age.

Rocks of Ordovician age are limestone, quartzite, and dolomite. They include the Pogonip group, Eureka quartzite, and Ely Springs dolomite and have a combined thickness of about 2,200 feet.

Rocks of Silurian and Devonian age are dolomite, limestone, and sandstone and include the Hidden Valley dolomite of Silurian and Early Devonian age and Lost Burro formation of Devonian age. These rocks are about 3,500 feet thick.

Rocks of Carboniferous and Permian age are about 5,500 feet thick and include limestone, shale, sandstone, and conglomerate. The rocks of Carboniferous age include the Tin Mountain limestone of Mississippian age, Chainman shale of Mississippian age, and arenaceous fusulinid limestone of Pennsylvanian age. The rocks of Permian age are shale, arenaceous fusulinid limestone, sandstone, and conglomerate.

Rocks of Triassic age consist of a section of about 1,800 feet of marine shale and limestone.

All the pre-Tertiary sedimentary rocks of the White and Inyo Mountains are much more dense and higher in seismic velocity than the rocks of Cenozoic age in the valley blocks, and, in the discussions that follow, they will be considered as a single sequence of undifferentiated sedimentary rocks of pre-Tertiary age.

\section{METAMORPHIC ROCKS}

The metasedimentary rocks of the Sierra Nevada are Paleozoic and Mesozoic in age and occur as roof pendants or septa in the main batholithic mass. The Paleozoic rocks are derived chiefly from pelitic, arenaceous, and calcareous sediments, whereas the Mesozoic rocks contain abundant volcanic but little calcareous material. Little fossil evidence is known on which to date these metasedimentary rocks, but Mayo (1931) described crinoid stems and brachiopods of Middle Devonian(?) age that were found by a prospector in limestone on a mountainside near Laurel Creek in southwestern Mono County. Rinehart, Ross, and Huber (1959) described Early Ordovician to Permian(?) fossils in the Mount Morrison roof pendant south of Long Valley and Early Jurassic pectens from a locality west of Long Valley. They believed also that the locality from which the fossil described by Mayo (1931) came probably contains the same marble unit as the one in which they found a suite of Pennsylvanian fossils.

Metasedimentary rocks of Precambrian age, which have interbedded volcanic rocks, in the northern White 
Mountains have been identified by Anderson (1937). These rocks have been intensely metamorphosed by intrusive rocks and include argillite, quartzite, limestone, and schist, which are unconformably overlain by rocks of Cambrian age.

Metavolcanic rocks of Triassic age are found along the crest of the Sierra Nevada, in the western part of Alabama Hills, and in the Inyo Mountains east of Lone Pine. These rocks include sheared andesite and rhyolite flows, schistose metatuff, and intercalated red and green shales and crossbedded sandstone (Mayo, 1941; Bateman and Merriam, 1954).

\section{CENOZOIC ROCKS}

Rocks of Cenozoic age include the lake beds, alluvial fan deposits, and glacial moraines of the Owens Valley area and the bounding mountain slopes and include a variety of rhyolitic and basaltic flows, tuff, and breccia. Recent soil and windblown sand cover much of the Owens Valley area. Knopf (1918, p. 48-58, 72-78) described these rocks. The lacustrine and fluviatile deposits and the pyroclastic rocks of Cenozoic age are significantly less dense and lower in seismic velocity than the pre-Tertiary rocks that confine them. These lighter rocks were deposited during and after the block faulting and warping that created the basin and range structural features of the Owens Valley area.

\section{OLDER LAKE BEDS}

Lake beds that may be either late Pliocene or early Pleistocene in age are exposed in several places in Owens Valley. Only one of these sequences of lake beds-the Coso formation-can be dated with any certainty, however.

The Coso formation of late Pliocene or early Pleistocene age is found in the basin between the Inyo Mountains and the Coso Range and extends southward across the low divide between Owens Valley and Rose Valley. It rests on an erosional surface cut in the granitoid rocks of the Coso Range. The Coso formation is the same as the unnamed sequence of lake beds south of Keeler described by Knopf (1918, p. 51), who considered it to be the oldest of the lacustrine deposits in Owens Valley. It has been studied more recently by Schultz (1937), who, on the basis of vertebrate fossils found in the coarse alluvial-fan materials of the base, considered it to be transitional between late Pliocene and early Pleistocene in age and by Hopper (1947), who regarded it as early Pleistocene in age and probably correlative with the McGee (Nebraskan) tills of Blackwelder (1931).

The Coso formation is about 500 feet thick. The base of the formation consists of alluvial materials composed of red arkose and buff gravel, which are derived from the granitoid core of the Coso Range; above the base is a sequence of sandstone and shale. Above these lower members is about 200 feet of thin-bedded white and light-buff lake beds and interbedded white rhyolitic tuffs. The lake beds are well-sorted silts and sands that locally contain fish bones; the tuffs also are well sorted and were probably laid down in a lake.

The Coso formation is overlain with no angular discordance by basaltic lava sheets; these sheets of basalt were deformed by faulting. The Coso formation on the west flank of the Coso Range dips an average of $10^{\circ}$ (but as much as $20^{\circ}$ ) toward the Sierra Nevada. The steeper dips are largely the result of deformation during the Pleistocene (Hopper, 1947).

Schultz (1937) considered the lake beds east of Big Pine to be probably almost the same age as the Coso formation. Hopper (1947), however, considered these lake beds to be younger, and probably correlative with the Sherwin (Kansan) glaciation of Blackwelder (1931). The lake beds in Waucoba Canyon were first studied by Walcott (1897), who concluded that deformation of these beds was evidence of post-Pleistocene elevation of the Inyo Mountains. Knopf (1918, p. 49), however, showed that some of the supposedly deformed lake beds were in reality younger alluvial-fan materials.

The lake beds in Waucoba Canyon (referred to as Waucobi Canyon by Walcott, 1897) are exposed east of Big Pine in the foothills of the Inyo Mountains. They are white or light gray, are composed of shale, sandstone, conglomerate, limestone, and arkosic grits, and contain freshwater gastropods. All these beds except the limestone and grits are soft, poorly consolidated, and evenly stratified in thin beds that are as much as 2 feet thick. They dip west at angles of less than $6^{\circ}$ and are about 150 feet thick. The lake beds are unconformably overlain by alluvial fans.

Seven miles south of Big Pine, several hundred feet of evenly bedded soft sandstone and shale, containing some diatomite and a fresh-water fauna, is exposed. These beds strike N. $40^{\circ} \mathrm{W}$. and dip $30^{\circ} \mathrm{SW}$., mostly as a result of fault deformation. They are partly covered by a basalt flow and are considered by Knopf (1918) to be probably Pleistocene in age. East of Inpedence along the flank of the Inyo Mountains, crudely layered beds containing fragments of granite, limestone, chert, and quartz are exposed. Most of the fragments are angular, but some are well rounded. These beds, possibly of lacustrine origin, dip $14^{\circ}-20^{\circ} \mathrm{W}$.

Underlying the welded tuffs capping the Volcanic Tableland, some 70 feet of nearly horizontal beds of rhyolitic composition is exposed. These beds consist of material that ranges from particles having the fineness of dust to well-rounded pebbles of pumice $1 / 2-1$ 
STRUCTURAL GEOLOGY AND VOLCANISM, OWENS VALLEY, CALIF.

inch in diameter. They are evenly bedded, and the individual beds are 2-3 inches thick. In places the coarser beds display crossbedding in which the foreset-type beds dip about $15^{\circ} \mathrm{E}$. These lake beds are composed of rhyolitic ash, grains of quartz, small pebbles of white pumice, and particles of black obsidian. Northeast of Laws are evenly stratified lake gravels that dip $14^{\circ} \mathrm{W}$. The beds northeast of Laws are unconformably overlain by alluvial fans.

\section{YOUNGER LAKE BEDS}

Long Valley was filled with a lake during a part of Pleistocene time. According to Rinehart and Ross (1957), the extrusion of the Bishop tuff of Gilbert (1938) blocked the part of the Owens River valley south of what is now artificial Lake Crowley and impounded a lake at least 80 square miles in area. Mayo (1934) estimated the greatest depth of the lake to have been 250 feet or more. Deposition of lake beds continued until the waters spilled over from this lake and cut the Owens River Gorge into the Bishop tuff and the lake was drained (Rinehart and Ross, 1957). This interpretation, requiring continuity of the course of Owens River from Long Valley into Owens Valley prior to the extrusion of the Bishop tuff, is supported by gravity evidence of an old relatively mature valley buried under the Bishop tuff.

The lake beds in Long Valley are at least 100 feet thick. The lower 50 feet includes strata of clay, silt, marl, and some diatomite. These lower beds are overlain by 5-50 feet of delta beds that are made up of coarse crossbedded tuffaceous sandstone containing opal cement (Mayo, 1934). Some of the coarse lake beds near the west margin of Long Valley may be Pliocene in age.

Owens Lake formerly extended at least 10 miles north of Lone Pine and covered an area of about 220 square miles. Knopf (1918, p. 57-58) noted that the lower course of Owens River southeast of Independence has cut a trench 20 feet deep and 200 yards wide in horizontally bedded ash-gray silts and fine sands, which are about 30 feet thick. A hole drilled to a total depth of 920 feet near the center of Owens Lake penetrated beds composed predominantly of clay for the first 750 feet and of alternating beds of clay, sand, and silt below that (Smith and Pratt, 1957). Ostracodes and diatoms were abundant in the cores taken from the drill hole.

During the ice ages Owens Lake was one of a system of interconnected lakes that filled the Searles and Panamint basins and probably overflowed into Death Valley (Gale, 1915). Gale estimated, on the basis of the salinity of the Owens Lake waters, that the last overflow occurred about 4,000 years ago after which Owens Lake became a closed basin. Old beach deposits indicate that the Owens Lake waters had once been 220 feet higher than they were in 1912, when the lake was about 30 feet deep. In 1920 the city of Los Angeles completed an aqueduct through which the waters of Owens River are transported to Los Angeles, and Owens Lake has since receded to a small pool of brine.

Late Pleistocene and Recent lake beds are also exposed in several places west of the front of the White Mountains north of Laws.

\section{ALLUVIAL FANS}

Knopf (1918, p. 52-57) mapped alluvial fans of two different ages along the front of the Inyo and White Mountains; he found only a single system of fans along the Sierra Nevada.

The great alluvial fans along the Sierra Nevada are 1-7 miles wide and converge to form a continuous apron at the base of the Sierra Nevada escarpment. These fans rise from 1,000 to 2,500 feet above the floor of Owens Valley and have an average slope of $6^{\circ}$ or $7^{\circ}$. The alluvial-fan materials consist of coarse angular gravels that are unsorted and crudely layered; they contain blocks as large as $18 \times 6 \times 8$ feet. According to Knopf (1918, p. 57) "the alluvial cones along the base of the Sierra Nevada attained their present height before the advent of the first glacial epoch, and the period of their upbuilding probably corresponds to that of the older alluvial cones along the Inyo Range." However, Knopf recognized only the two more recent of the glacial stages of Blackwelder (1931), so this statement is not applicable to the older McGee and Sherwin glaciation. The fans along the Sierra Nevada have been dissected to depths ranging from 75 to 150 feet, according to Knopf (1918), as a result of the increased erosive power of the unladen streams after glaciation and possibly also of renewed uplift of the mountain block.

The younger fans along the White and Inyo Mountains were derived largely from erosion and partial destruction of the older fans, but new material eroded from the mountains has undoubtedly been added to these fans. The older fans extend back into the canyons to an altitude of 6,600 feet $(2,600$ feet above the valley floor). The coarse angular irregularly layered gravels of the older fans contain boulders of granite 6-12 feet in diameter. The beds of the older fans have been dislocated and tilted so that they now dip as much as $50^{\circ}$ W. (P. C. Bateman, written commun., 1958). The younger fans at the base of the mountains are small, but pronounced, typical alluvial fans. Along the northern White Mountains, however, the alluvial fans are extremely well formed into a continuous apron at the 
base of the mountains similar to that along the Sierra Nevada. Older gravels, in places covered by the Bishop tuff of Gilbert, have been mapped in the northeastern part of the Casa Diablo Mountain quadrangle by Rinehart and Ross (1957).

Knopf $(1918$, p. 56-57) related the formation of the older fans to a period of increasing aridity during which the streams dropped their loads nearer and nearer to the heads of the canyons. Alluviation in the canyons was interrupted by faulting, after which, during the glacial epochs, the climate became more humid, the competence of the streams was increased, and the new fans were formed. Deposition of the new fans is now at a standstill because of the present arid conditions, and alluviation is going on in the canyons (Knopf, 1918 , p. 56). P. C. Bateman (written commun., 1958) concluded, on the basis of recent detailed geologic mapping in the area surrounding Bishop, that all the older fans have been dissected because of structural movements and not because of climatic change; he also noted older dissected fans along the east base of the Sierra Nevada between Bishop and Lone Pine.

\section{GLACIAL DEPOSITS}

Knopf (1918, p. 92-105) found evidence of two periods of glaciation on the eastern slopes of the Sierra Nevada. Moraines deposited during the earlier of these two periods extend downward to altitudes of about 5,000 feet in the canyons that drain into Owens Valley, and these moraines cover the upper slopes of alluvial fans. The moraines of the later glacial period are found only on the higher slopes of the canyons, where they overlie the older moraines. Knopf $(1918$, p. 93) also found evidence of glaciation on the east side of the northern White Mountains. Anderson (1937) described moraines of the Tioga glacial stage (Blackwelder, 1931) and of an earlier stage in the same area. The till of these more recent glacial stages is an unsorted and unstratified accumulation of angular boulders of granite, quartzite, schist, and basalt.

Blackwelder (1931) made an intensive study of the glaciation in the Sierra Nevada and found evidence of four glacial stages, which-from older to younger-he named the McGee, Sherwin, Tahoe, and Tioga glacial stages. Blackwelder tentatively correlated the Sherwin glacial stage with the Glacier Point and El Portal glacial periods of Matthes (1930, p. 50-75) in the Yosemite Valley area and correlated the Tahoe and Tioga glacial stages with the Wisconsin of Matthes in Yosemite Valley. Blackwelder considered the McGee moraines to be Nebraskan in age, the Sherwin deposits to be equivalent to Kansan, and the Tahoe and Tioga to be Wisconsin. No evidence of Illinoian glaciation was found by Blackwelder in the Sierra Nevada, but he suggested that such evidence would eventually be found.

Remains of the moraines of all the glacial stages of Blackwelder are preserved in the Owens Valley area, and the Tahoe and Tioga moraines are little altered. The two glacial epochs of Knopf are presumably the same as the Tahoe and Tioga of Blackwelder. The Sherwin till, which was more extensive than the tills of the Tahoe and Tioga, is exposed east of the mouth of Rock Creek canyon and in the Owens River Gorge, where it overlies basalt but is under the Bishop tuff of Gilbert (Rinehart and Ross, 1957). Tills of the Sherwin, Tahoe, and Tioga stages are especially abundant in the canyons draining into Long Valley from the Sierra Nevada, and the moraines form prominent ridges that project from the mouths of the canyons onto the slopes of the alluvial fans. Contrasted to the well-formed moraines of the Tahoe and Tioga glacial stages, the Sherwin till is almost formless. McGee till is found on McGee Mountain, which towers above Long Valley. According to Blackwelder (1931, p. 904) :

the deposits on Mount McGee antedate the present eastern front of the range with its deep canyons. It is reasonable to suppose that while such great topographic changes were being brought about, the mountain peaks of that day were largely demolished and have been succeeded by others that now adorn the land. scape.

The younger Tahoe and Tioga glaciers, successively less extensive, tended to follow the same canyon paths as the Sherwin glaciers.

\section{VOLCANIC ROCKS NORTH OF BISHOP}

Long Valley and Mono Basin have been subjected to a sequence of violent volcanic eruptions and explosions since the close of Miocene time. Although no volcanos are now active in this area, volcanism was probably not complete until late prehistoric time, and hot springs now discharge their vapors in many places. Gilbert $(1938,1941)$ made a detailed study of the volcanism southeast of Mono Lake and tentatively correlated the earlier volcanic rocks with similar rocks in the Hawthorne quadrangle and the Sweetwater Range of Nevada. Chelikowsky (1940) studied the rhyolite near the center of Long Valley. More recently, Rinehart and Ross (1957) did detailed geologic mapping in the Long Valley area. Most of the discussion of volcanic rocks that follows has been summarized from the papers of Gilbert $(1938,1941)$.

VOLCANIC ROCKS OF TERTIARY(?) AGE

The oldest volcanic rocks in the area north of Bishop and southeast of Mono Lake are rhyolite. The rocks are composed of vitric-crystal tuff and consist of three 
massive members. An erosional surface separates them from the overlying andesite breccias, conglomerates, and flows. They are best exposed on the summit and eastern flank of the Benton Range about 4 miles northnorthwest of Benton. The lowest member, about 25 feet thick, is composed of a dull-gray matrix of poorly sorted and partly devitrified glass shards in which are scattered crystals of quartz and sanidine, larger fragments of light- and dark-gray pumice, and pellets of obsidian. The middle member is thicker and contains more fragments of biotite, sanidine, and quartz scattered in a dull-white matrix of devitrified glass; it contains also a few lapilli of white devitrified pumice. The upper layer is dark gray, contains more abundant crystals of quartz, sanidine, biotite, oligoclase, and hornblende, and contains lapilli of porphyritic pumice as much as 2 inches in diameter; it is about 25 feet thick. Gilbert considered these rhyolitic rocks to be of subaerial origin and made up of material supplied by volcanic explosions.

The andesite that unconformably overlies the rhyolite is composed mainly of massive beds of breccia containing blocks of hornblende-pyroxene andesite as much as 3 feet in diameter. The andesite is about 200 feet thick and is separated from the basalt above it by an unconformity. Along the east flank of the Benton Range, where the stratigraphic relationships are clearest, the andesite dips about $20^{\circ} \mathrm{E}$. The andesitic rocks consist of beds of andesitic conglomerate and tuff and of a single flow of hornblende-pyroxene andesite. The beds of conglomerate range in thickness from 1 to 10 feet and include large fragments that are subangular to subrounded. The finer tuff members are fairly well sorted and evenly bedded. Boulders of granodiorite, quartzite, and andesite tuff are found in a breccia about 5 miles north of Benton Station. The andesite was ejected probably from central vents from which cones were built. The location of these vents is not known, but it was probably to the north of the Benton Range, as is indicated by the general thickening of the andesite in that direction. Gilbert regarded the breccias as mudflow deposits and the conglomerates and tuffs as having been deposited by streams and floods.

The olivine basalt that unconformably overlies the andesite is widely distributed throughout the area north of Bishop and southeast of Mono Lake. It consists of a series of noncontinuous flows having a maximum thickness of 600-700 feet east of Bald Mountain and on the Sierra Nevada crest. The individual flows are 25-50 feet thick; scoria are found at the top of each flow, and vesicles are found at the bottom. Fragmental material is found in the basalt only where it underlies the Bishop tuff of Gilbert in Owens River Gorge and on the Sierra Nevada crest west of Bald Mountain. The basalt has been elevated by block faulting and forms the capping of several ranges. Bedded rhyolite tuffs that have been displaced by faulting overlie the basalt north of Benton; south of Benton the tuffs lie on an eroded surface of granite. The basalt issued from scattered vents and flooded the broad valleys of an old erosion surface.

The summit and western side of Bald Mountain are covered by a dark-gray hornblende andesite. This andesite has a flow structure of parallel crystals of hornblende that dips into Bald Mountain at angles of $20^{\circ}$ or $25^{\circ}$. Gilbert (1941) believed that the andesite was intruded into the basalt before the basin and range faulting in the area; the andesite is overlain by the Bishop tuff.

The slopes of Glass Mountain and its neighboring peaks are covered by glassy and lithoidal rhyolite flows between which beds of tuff may exist. The rhyolite erupted probably from vents above the southern flank of Glass Mountain Ridge near the summit. The rhyolite is several thousand feet thick and has been displaced by faulting; so, the southern part now probably lies buried beneath the alluvium of Long Valley. According to Gilbert (1941, p. 795-797) :

the faulting succeeded the rhyolitic eruptions for the southern slope of the range is a fault scarp along which not only the rhyolite but the underlying granitic and basaltic rocks east and west of Glass Mountain have been displaced. [The pre-rhyolite] basement of Glass Mountain is an irregular, basinlike, structural depression, perhaps formed by downwarping and faulting during the rhyolite eruptions, perhaps after these eruptions, or possibly both during and after the eruptions.

West of the Benton Range rhyolite tuff covers a part of Long Valley. The tuff overlies olivine basalt and is buried to the south under the Bishop tuff. In places it has been displaced by normal faults. Fragments of white pumice, chips of lithoidal rhyolite, pellets of obsidian, and crystals of quartz and feldspar are scattered through a matrix of glass dust. This tuff was probably erupted explosively from volcanic pipes.

A bedded rhyolite-tuff sequence extends northward from Glass Mountain toward Adobe Valley (fig. 2) and east of the Benton Range. It consists of unconsolidated rhyolite tuff, of gravel made up of fragments of glass, quartz, and feldspar, and of pebbles and subangular boulders of rhyolite and obsidian. This series of rhyolitic beds was derived from Glass Mountain and was quickly spread on a surface of low relief by streams flowing to the north and east. In places it is crossbedded. The tuff sequence overlies basalt and is overlain by the Bishop tuff. The maximum thickness of these beds is not more than 500 feet; a section 200 feet thick is exposed near Benton. In places the tuff is dis- 
placed by normal faults, and part of it was stripped from the ranges being uplifted and was deposited downslope on the original beds of alluvium.

Correlation of the volcanic rocks southeast of Mono Lake with those in the Hawthorne quadrangle of Nevada "indicates that the lavas southeast of Mono Lake are younger than the uppermost Miocene sediments exposed in the Hawthorne quadrangle, mapped by Ferguson as the 'Esmeralda formation'" (Gilbert, 1941 , p. 801). Correlation with a similar sequence of volcanic rocks in the Stillwater Range yields a similar result. The Esmeralda formation, a sequence of lacustrine and fluviatile deposits containing volcanic rocks in the upper part, is probably early Pliocene in age, according to Gilbert (1941), and is younger than the Esmeralda of Ferguson. The older volcanic rocks southeast of Mono Lake and north of Bishop, therefore, are probably early or middle Pliocene in age. The rhyolite of Glass Mountain is younger than the Tertiary basalt flows and is probably middle Pliocene in age.

VOLCANIC ROCKS OF PLEISTOCENE AGE

"Following the initiation of normal faulting, volcanic eruptions continued through the Pleistocene period until recent time" in the area southeast of Mono Lake and north of Bishop (Gilbert, 1941).

The oldest of the volcanic rocks of Pleistocene age is the Bishop tuff of Gilbert (1938). The age of the Bishop tuff has recently been determined by potassiumargon dating to be about 1 million years (Evernden and others, 1959). Basin and Range faulting was nearly complete when the tuff from scattered vents in the Long Valley area was deposited as ash flows on an old erosion surface. Moraines of the Sherwin(?) stage are buried by the Bishop tuff, and the tuff is overlain by moraines of the last two glacial stages. The geologic age of the Bishop tuff, therefore, is probably middle Pleistocene-post-Sherwin and pre-Tahoe. The total exposed area of the Bishop tuff is about 350 square miles; the total area the tuff covers is probably 400-450 square miles. It was found in the Los Angeles Aqueduct tunnel, where it underlies the Mono Craters; east of the Mono Craters it is buried under pumice. The tuff extends also beyond the exposed area under the alluvium of Owens, Long, and Adobe Valleys. The base of the tuff is exposed in Owens River Gorge, in youthful streams along the south margin of Adobe Valley, and along the south and east edges of the Volcanic Tableland. Gilbert (1938) estimated the total thickness of the Bishop tuff to be about 400-500 feet, but it is at least 800 feet thick in places (Rinehart and Ross, 1957). The total volume of the tuff is about 35 cubic miles or more. The Bishop tuff is composed of rhyolitic material; it is welded and poorly bedded and sorted. Its density increases with depth because of the compaction of the viscous gassy "pumice" of the hot ash flow from which it formed.

Later in the Pleistocene, several basalt flows poured eastward into the western part of Long Valley, where they are probably overlain in places by domelike protrusions of biotite-hornblende andesite. Another olivine basalt sheet flowed from the base of the Sierra Nevada eastward toward the site of Mono Craters. The rhyolite eruptions near the center of Long Valley consist of "siliceous extrusions of the fissure type, but [they] are not tuffaceous in character. They are true lavas and only locally grade into fragmental obsidian or pumice" (Chelikowsky, 1940, p. 422). Gilbert (1941), agreeing with Chelikowsky, regarded these rhyolites as late Pleistocene in age. However, C. D. Rinehart (written commun., 1957) believed that they may correlate with the rhyolite of Glass Mountain.

Mono Craters erupted late in the Pleistocene and scattered pumice over much of Mono Basin; the volcanic peaks were built from rhyolite obsidian and pumice ejected from the vents. Putnam (1949) showed that the latest pumice covers late recessional moraines of the Tioga glaciation. The absence of old shorelines on the slopes of the northern Mono Craters (Putnam, 1949) indicates the recency of these eruptions. The early Mono Craters are about 65,000 years old, and the youngest are about 6,000 years old, according to recent dating by the potassium-argon method (Evernden and others, 1959).

\section{VOLCANIC ROCKS OF OWENS VALLEY}

Eruptions of rhyolitic and basaltic materials occurred intermittently during late Tertiary (?) and Pleistocene times along the margins of Owens Valley south of Bishop. The volcanic rocks of Owens Valley were first studied systematically by Knopf (1918, p. 72-78); more recent information on their character and distribution was added by Schultz (1937), Mayo (1941), and Hopper (1947).

Knopf (1918, p. 74) found evidence that basalt flows occurred three times from late Tertiary (?) to Pleistocene. The earliest of these flows, considered by Knopf to be late Tertiary, is exposed in the Inyo Mountains southeast of Keeler. The basalts southeast of Keeler aggregate about 100 feet in total thickness and rest on a nearly horizontal surface eroded across dipping beds of Triassic and Carboniferous ages. Basalt sheets flowed over the lake beds between the Inyo Mountains and the Coso Range, where they now form plateaus on the east side of the Inyo Mountains (Knopf, 1918, p. 74). These basalt sheets have a total thickness of about 125 feet and are younger than the ostracode-bearing 
beds that they cover (the Coso formation). They were displaced by the faulting that gave rise to the present Inyo Mountains and are, according to Knopf (1918, p. 74), probably late Tertiary in age. Hopper (1947) described similar basalt in the Coso Range that covers an old erosion surface and caps the Coso formation. The basalt described by Hopper is correlative with the late Tertiary (?) basalts described by Knopf; and Hopper (1947) correlated this basalt with a thin olivine basalt that in places covers the Ricardo formation 40 miles south of the Coso Range, thus dating the basalt as late Pliocene or early Pleistocene in age. Schultz (1937) found evidence of two periods of basalt extrusion in the Coso Range; faulting, followed by erosion, separated the extrusions of the basalts.

Basalt of Pleistocene age, considered by Knopf (1918, p. 74) to be preglacial (pre-Tahoe), is exposed in a canyon west of Independence. Similar basalt, which is about 200 feet thick, also overlies the older alluvial fans of the east side of the Inyo Mountains and is found in isolated patches on the Sierra Nevada slopes southwest of Bishop; a few small patches are found west and northwest of Bishop.

A conspicuous volcanic field of basalt, surrounding Crater Mountain and Red Mountain, may be seen on the east side of the Sierra Nevada between Big Pine and Independence. A north-trending fault connects Crater and Red Mountains (Mayo, 1941). Basalt of similar age is found along the east side of Owens Valley east of Red Mountain. These basalts are probably late Pleistocene in age.

Massive rhyolite, probably late Tertiary in age (Knopf, 1918, p. 72-73), is exposed 8 miles south of Big Pine. Latite of late Tertiary age is found in scattered outcrops in the Sierra Nevada.

\section{STRUCTURE AND PHYSIOGRAPHY}

OIDER STRUCTURAL FRAMEWORK

The metasedimentary and metavolcanic rocks of the septa or the roof pendants of the Sierra Nevada are generally more dense than the plutonic rocks of the batholith that contain them; so, the gravity data in the mountain slopes bounding Owens Valley show local evidences of the Nevadan orogeny. The very great contrast in density between the pre-Tertiary rocks and the clastic rocks of Cenozoic age that fill the valley blocks is, however, by far a greater influence on the gravity field. The gravity data therefore reveal vital information about Basin and Range structural features and directly reveal only little of the very great deformation of earlier orogenies. The structural features of these earlier orogenies, however, had an important influence on Basin and Range block faulting.
Mayo (1941) made a thorough study of these older structural features and their control over the faults along the eastern front of the southern Sierra Nevada. Structural features mapped by Mayo include isoclinal folds, cleavage, linear structures, shears, rock flowage, joints, contacts of metasedimentary and metavolcanic rocks with intrusions, inclusions in granitic rocks, schlieren, and preferred orientation of minerals. $\mathrm{He}_{\boldsymbol{\theta}}$ found four important structural trends: a dominant northwesterly trend parallel to the Pacific coast, a northeasterly "cross grain," a system of generally northnortheasterly trends ranging from north to N. $30^{\circ} \mathrm{E}$., and another system of generally west-northwesterly trends ranging from $\mathrm{N} .60^{\circ} \mathrm{W}$. to west.

Basin and Range faults follow the same directions, the northwesterly direction, parallel to the Pacific coast, also being the dominant one. In the Owens Valley area, for example, the dominant faults west of northern Owens Lake follow the Pacific coast directions; many small faults west and southeast of Owens Lake trend north-northeast; and the Darwin "tear fault" and the faults east-southeast of Owens Lake trend westnorthwest (Mayo, 1947). Mayo (1941, p. 1064) concluded that "the major features of the framework of oldest structures are again reflected, this time in the arrangements of the faults along the eastern front of the Sierra Nevada."

Webb (1946, p. 375), postulated that the Great Western Divide may "have been inherited from the Nevadan orogeny rather than to be the result of Sierran rejuvenation." According to Webb, the Middle Kern Basin has been drained since the close of Nevadan time by a south-flowing stream; the Great Western Divide, now transgressed by the Kern River, was the original master drainage divide, and the present Sierra Nevada, having the drainage divide at the crest near the eastern escarpment, was built by repeated movements along the Sierra Nevada fault at the eastern base of the range. Webb regarded the Kern Canyon fault as probably Nevadan in age. The direction and amount of movement along the fault is not known and all the present physiographic features in the Kern Canyon area have been affected by erosion after the faulting occurred. Lawson (1904), however, regarded the faulting as coincident with the period of canyon cutting. Drainage parallel to Nevadan structural trends is not uncommon on the western slope of the Sierra Nevada.

Locke, Billingsley, and Mayo (1940) compiled a map of the tectonic trends of the Sierra Nevada region based on cleavage, bedding, flow, and shear layers in both the metamorphic and granitic rocks. They believed that the exposed edges of these layers combine into lanes, such as the San Andreas rift, and curves, such as the 
westward hook of the southern part of the Sierra Nevada, and concluded that

the Slerra becomes a shift zone with the principal motion horizontal shear along the lanes, and with displacement northwestward on the Pacific side. Subsidiary motion starts at inequalities in strength and creates curves in which the inner parts are thrust upward and outward toward their convex sides. The resultant motion is clockwise in horizontal section.

P. C. Bateman (written commun., 1959) summarized the significant features: (1) the prebatholith rocks were folded along north- to northwest-trending lines, with the average trend $\mathrm{N} .30^{\circ} \mathrm{W}$., (2) the long axis of the batholith is parallel to this trend, as are the axes of many individual plutons, (3) mafic dikes also trend generally about $\mathrm{N} .30^{\circ} \mathrm{W}$., but in places a set trends $\mathrm{N}$. $70^{\circ} \mathrm{W} .,(4)$ joints trending northeastward and northwestward are present along the west side of the batholith, but these are probably related to Cenozoic rather than earlier deformation, and (5) the average trend of Owens Valley is N. $17^{\circ}$ W., and it cuts across the trends of folds in the prebatholith rocks.

\section{BASIN AND RANGE STRUCTURAL FEATURES}

The most distinguishing characteristics of Owens Valley and the related downdropped structural features to the north and northwest are the nearly linear trend of the western front of the White and Inyo Mountains and the irregularity, marked by successive offsets to the west, of the eastern front of the Sierra Nevada from south to north (fig. 2). Whether these differences are the result of differences in the ancestral structural trends, the lithologic boundaries, or the differences in the history of deformation, ar all of these, is, of course, an unanswered question. The gravity data, as shall be shown on pages $22-39$, confirm, in general the remarkable simplicity of the bounding fault of the eastern side of Owens Valley, its structural extension to the north, and the notable complexity of the deformation, which involves both faulting and warping, of the western boundary. Another less striking difference between the western front of the White and Inyo Mountains and the eastern front of the Sierra Nevada is the relative paucity of evidence of volcanism along the eastern boundary of Owens Valley and the abundance of such evidence along the western boundary.

The western front of the White Mountains and of the transition zone between the White and Inyo Mountains north of Waucoba Mountain trends a few degrees west of north along a nearly straight line. Indeed, on small-scale maps a straightedge can be readily used to define this front. The western front of the Inyo Mountains is offset abruptly to the west and is rotated slightly in a counter-clockwise direction south of an east-trending line through Red Mountain, and the linear front continues, trending a few degrees west of north, nearly to the southern terminus of the range. The White Mountains are terminated abruptly by a steep arcuate escarpment just north of the map area (fig. 2) and east of Mono Lake. On the south the Inyo Mountains are terminated by a series of basalt plateaus that are remnants of a continuous sheet of basalt that has been broken by normal step faults. This is the most conspicuous volcanic field in the White and Inyo Mountains. Another smaller basalt flow is found along the western front of the Inyo Mountains immediately to the east of Red Mountain in the zone of westerly offset of the White-Inyo Mountains chain; the flow may be related to this offset.

The near-linear trend of the western front of the White and Inyo Mountains strongly suggests that it is a continuous fault scarp, but there is little direct geologic evidence that this is true. Short fault segments in the alluvial fans and in the bedrock along the White and Inyo Mountains front have been mapped by Bateman, Nelson, Merriam, and Smith (Bateman and Merriam, 1954) and by Knopf (1918, p. 88-90), Hopper (1947), Anderson (1937), and Gilbert (1941), but most of these are subsidiary faults that lie east of the main bounding fault. As Knopf (1918, p. 88-90) noted, however, the White and Inyo Mountains front cuts across axes of highly folded strata. The lack of conspicuous evidence for faulting along most of the western front of the White and Inyo Mountains may indicate that the faulting is distributive, as Knopf (1918, p. 89) suggested, or that warping (in addition to distributive faulting) is an important mode of deformation. P. C. Bateman (written commun., 1956) demonstrated the abundance of "mountain-down" faults, as well as "valley-down" faults, along the mountain front. He regarded mountain-down faults as evidence of warping. The association of mountain-down faults with warping is confirmed along the Coyote warp on the eastern slopes of the Sierra Nevada south of Bishop but, as the gravity data indicate, a profound break in the earth's crust occurs along the front of the White and Inyo Mountains. Therefore, although mountain-down faulting may be a feature associated with warping, the warping must be incidental to major valley-down faulting. It is difficult to conceive of faulting of the magnitude of that in the Great Basin without some subordinate warping.

The physiographic evidence strongly indicates a single fault of large displacement along the western front of the northern White Mountains, where the steep scarp; deeply incised by youthful canyons, and the extensive alluvial fans rival those of the steepest slopes of the Sierra Nevada. In the northern White Mountains an uplifted surface of low relief occupies a large area of 
the crest, and upfaulted alluvium, most of it overlain by Pleistocene(?) basalt (Anderson, 1937), is found at altitudes as high as 10,000 feet. Anderson (1937, p. 6) described the White Mountains as a horst "with downthrown blocks on the east and on the west $* * *$. The western scarp is higher and steeper than the eastern one; the mountain block has been tilted toward the east." Deep Spring Valley is representative of the downdropped blocks on the eastern side of the White Mountains (Miller, 1928).

The Coso Range terminates Owens Valley on the southeast; it is a low range bounded by seven mappable faults on the west flank: An erosion surface of low relief extends over the summit of the Coso Range (Hopper, 1947).

Along the eastern front of the Sierra Nevada large westerly offsets of the front are found west of Bishop, where the Wheeler Crest escarpment is one of the most imposing along the Sierra Nevada, west of Long Valley, and west of Mono Basin; successive westerly offsets of the eastern front of the Sierra Nevada continue north of Long Valley to the junction of the Sierra Nevada with the Cascade Range. Volcanic fields commonly occur in these offsets, as in Long Valley (Mayo, 1941), Mono Basin, and Sierra Valley far north of the mapped area. The Sierra escarpment is very steep and is incised by youthful valleys between Olancha and Big Pine (fig. 1). North of Big Pine to Tungsten Hills, the evidence for faulting is not conclusive and, as P. C. Bateman (written commun., 1956) showed and as the gravity data confirm, warping may be the dominant mode of deformation in this area.

Knopf $(1918$, p. 79) recognized the physiographic contrast between the steep Sierra escarpment south of Big Pine and the relatively gentle slopes north of Big Pine; he regarded this contrast as evidence that distributive faulting may have been the important mode of deformation between Big Pine and Tungsten Hills and that the escarpment to the south represents a profound break in the earth's crust. Examination of figure 2 shows that the zone of change in the steepness of the Sierra Nevada escarpment near Big Pine, which presumably is evidence of a change in the mode of deformation from faulting on the south to warping on the north, lies opposite the sharp shift in the western escarpment of the Inyo Mountains and in a zone of volcanism.

Alabama Hills lie east of the Sierra escarpment and immediately west of Lone Pine. The fault along which movement caused the great earthquake of 1872 defines the eastern base of the Alabama Hills, and other recent fault scarps are found in the alluvium in this area (Hobbs, 1910). Lone Pine Creek flows across the Al- abama Hills, which presumably rose as this stream cut a narrow canyon in the bedrock and maintained its course.

The conclusion of Knopf $(1918$, p. 90) that "Owens Valley is a great tectonic trough whose floor has subsided along a series of parallel faults" seems warranted on the basis of all available physiographic and surface geologic information. This conclusion is strongly supported by the geophysical evidence at hand.

North of Bishop, the graben between the Sierra Nevada and the White Mountain escarpments broadens to give a $Y$-shaped appearance to the modern drainage basin of Owens River. Included in the broad upper part of this $Y$ are Round Valley, Long Valley, the structural extension of the Owens Valley block north of Laws, and several smaller Basin Ranges, the most prominent of which are the Benton Range and Blind Spring Hill (fig. 2) ; these ranges separate Long Valley from the graben to the east. Gilbert (1941) and Rinehart and Ross (1957) studied this area and mapped the faults, for which there is abundant evidence. A bedrock high separates Round Valley from Long Valley. Lavas and tuffs of Tertiary (?) age that cap the Benton Range have been uplifted about 1,000 feet and tilted eastward. Where volcanic rocks are absent, an old erosion surface forms the eastward-tilted slope of the range, which, although it has been battered by erosion, has only small fans at the western base. Blind Spring Hill was uplifted about 1,000 feet without tilting; its summit is an erosion surface of low relief carved in the granite bedrock (Gilbert, 1941).

Glass Mountain Ridge is an east-trending mountain block bounded by a prominent fault scarp that faces the Sierra Nevada escarpment across Long Valley, which is to the south.

Although few of the faults of the Owens Valley area can be seen, those that are best revealed indicate that normal faults, whose dips range from $50^{\circ}$ to $80^{\circ}$, predominate. Although some authors mention the possibility of horizontal movement along the Sierra Nevada frontal fault, most seem to consider dip-slip movement to be predominant. Mayo (1941, p. 1063) observed 8 feet of left-lateral horizontal offset of a Recent mud-flow welt on Independence Creek, but he inferred predominant right-lateral offset on the basis of a shift in the course of the stream at the same place. Of the published reports on the earthquake of 1872 , only that of Hobbs (1910), which was based on the mapping of Willard D. Johnson in 1907, described rightlateral offset. The reports of Whitney (1872), Gilbert (1884), and Holden (1898) described or implied leftlateral offset. Most of the evidence of horizontal movement in the earthquake of 1872 has been lost, but Gianella (1959) recovered evidence of left-lateral offset 
in 3 places. Cordell Durrell (1950; written commun., 1959) found evidence of strike-slip movement along a fault in the eastern Sierra Nevada near Blairsden, Calif., having the same trend as Owens Valley. The direction of horizontal movement noted by Durrell was left-lateral, the northeast side of the fault having moved about 17,000 feet northwest relative to the southwest side; this movement is about five times the dip-slip component. Hopper (1947, p. 430) concluded that "horizontal shearing stresses were active in at least the latter part of the deformation" in the Sierra NevadaDeath Valley region. Nevertheless, dip-slip movement is important, perhaps predominant along a single fault, as the physiographic, geologic, and gravity data shows.

\section{VOLCANO-TECTONIC FEATURES}

Williams (1941), in his comprehensive study of calderas, suggested that the basin containing Mono Lake may have been formed like the volcano-tectonic depressions of the Pilomasin Basin of Sumatra by subsidence following extrusion of lava from a magma source below. The Long Valley basin may have been formed in the same way. Gilbert (1938) noted the possibility that the recent faulting in Long Valley is the result of the extrusion of a large volume of magma from beneath that area. Chelikowsky (1940, p. 438) stated:

It is believed that the early expulsion of the great volume of basic lavas, together with the material in the welded tuffs, which are disposed on three sides of the basin, led to the collapse of what is now Mammoth embayment. The cooling of the early basic eruptions strengthened the initial weak zone along which the collapse occurred and shifted the site of later activity farther to the east. Subsequent volcanism accompanied by a northwestward shift of the Sierra Navada mass caused the weak central portion of the embayment to yield and become intruded by the rhyolite **. It is therefore not surprising that the rhyolite flssure eruptions should have occurred in the ceutral, most twisted part of the embayment.

Mayo (1937, p. 184) described the formation of Long Valley, or what he later termed the Mammoth embayment, as follows:

About 18 miles south of Mono Lake a great re-entrant exists in the Sierra front. The Mono volcanoes trend into this re-entrant, and many other meridional structures strike into it. It appears that here a block of the crust, weakened by many fissures, has subsided below the general level. This block is encircled by faults, and tremendous volumes of lava and pyroclastic materials have been expelled along its northern and eastern sides. Protrusions and stubby flows of rhyolite (Rhyolite Hills) have issued from the intensely fractured floor of the re-entrant.

This interpretation in general is in agreement with present knowledge of the structure of the Long Valley block; this block has many of the features of a great caldera or volcano-tectonic depression as described by Williams (1941).
The authors believe that Long Valley and Mono Basin are volcano-tectonic depressions of the type described by Williams (1941) and that subsidence was related both to extrusion of lava and the framework of Basin:and-Range faults. To a lesser extent subsidence associated with volcanic extrusion may have been an influence elsewhere on the structure of the Owens Valley area.

\section{EVOLUTION OF THE PRESENT LAND FORMS}

Because of the paucity of fossil evidence that can be used to date the various episodes of orogenic movement and the subsequent physiographic development in the Sierra Nevada and the basin ranges to the east, the pioneering geologists relied heavily on physiographic evidence to deduce the sequence of geologic events. These early geologists, with the exception of Lawson (1904), almost unanimously emphasized the antiquity of the major structural features although they recog:nized the recency of the faulting that gave rise to the present great eastern escarpments. On the other hand, recent students, relying on what little paleontologic evidence is at hand, have tended to assign virtually all the present structural and physiographic features of the Sierra Nevada-Owens Valley region to movements dating from near the close of Tertiary time. Further, they have largely discounted or ignored the possibility that the history of deformation may have been quite complex through Cenozoic time and that movements may have taken place at different times along faults occurring near each other. The most recent work, that of Axelrod (1957), is based on studies of late Tertiary floras and their behavior under changing conditions of altitude and climate and again emphasizes the recency of the uplift of the Sierra Nevada and minimizes the importance of earlier movements.

Lindgren (1911, p. 41-43) postulated a complex history of faulting along the eastern front of the Sierra Nevada and wrote:

The main break along the east side of the range is one of great antiquity, probably dating back at least to the last part of the Cretaceous, but movements have recurred at different times, and the fault system became greatly extended by additional breaks at the close of the Tertiary. Post-Tertiary and recent movements have taken place in many localities *** . To sum up, faulting has recurred irregularly along the eastern fault zone since the Cretaceous period. The subsidences along the faults are not uniform. A Cretaceous dislocation along one line may be continued by a late Tertiary fault on the extension of this line.

More recent students of Basin-and-Range geology, including Nolan (1943), Jahns (1954), and Axelrod (1957), recognized that "adjacent fault blocks commonly have had distinctly different geologic histories, 
thanks mainly to the nature and timing of movements on the faults that separate them" (Jahns, 1954, p. 13).

King (1878, p. 744), even before Lindgren, postulated that movement along the Sierra Nevada fault began early, perhaps within Eocene time or at the close of the Eocene.

\section{PHYSIOGRAPHIC EVIDENCE}

Beginning with Lawson, the pioneering geologists deduced two important post-Eocene uplifts of the Sierra Nevada from their studies of the physiography of the Sierra Nevada uplands. All these early geologistsLawson, Lindgren, Knopf, and Matthes-recognized that the latest and probably greatest of these uplifts dated from latest Tertiary or more recent times. All but Lawson placed the initial uplift within the Tertiary; Lawson regarded it as early Pleistocene.

Lawson (1904) recognized three preglacial erosion surfaces in the Upper Kern River basin. The oldest of these he termed the Summit Upland and its related Subsummit Plateau (fig. 3). The Summit Upland was formed, according to Lawson, by stripping away the roof of sedimentary rocks to and in places below the upper surface of the granite core of the high mountain range of the Nevadan orogeny. The Subsummit Plateau was formed in the late stages of the erosion cycle in which the Summit Upland became mature and is found, in the Upper Kern River basin, at an altitude of about 11,500 feet above mean sea level. Chronologically, the Subsummit Plateau correlates in part with the Summit Upland, and both surfaces antedate the uplift and faulting of the eastern front of the Sierra Nevada.

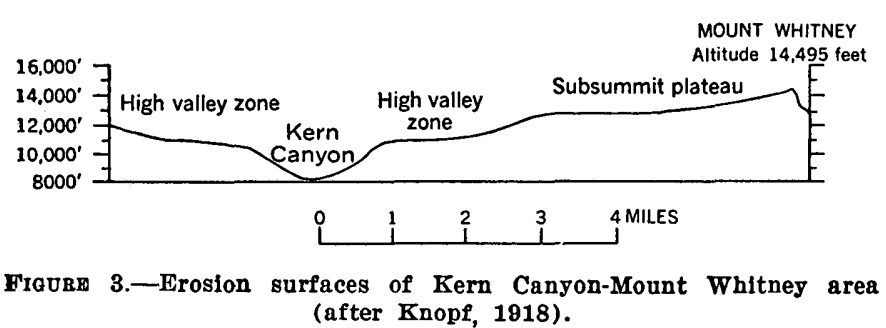

The High Valley zone of Lawson was cut after the initial uplift of the Sierra Nevada in what Lawson regarded as the beginning of Pleistocene time. Mature valleys, about 2,500 feet deep, were formed during this stage of erosion. Representative of them are the Chagoopa Plateau, Toowa Valley, and the Little Kern Plateau.

The Canyon zone of Lawson was cut after the second, greater uplift and is represented by the present deep canyons of the Sierra Nevada at altitudes too low to have been subjected to glacial erosion. The present
Middle Kern Canyon was, according to Lawson, cut along a fissure or graben that formed at the same time as the canyon cutting. Webb (1946), however, postulated that the Kern Canyon fault predates the canyon and may have been formed in Nevadan time.

Lawson estimated the duration of the Pleistocene as about $23 / 4$ million years, which is much longer than present estimates of about 1 or $1 \frac{1}{2}$ million years (Evernden and others, 1959). He did not, however, have benefit of present knowledge of the glacial stages in the Sierra Nevada, nor did he have any fossil evidence. He cited no direct evidence for dating the initial uplift of the Sierra Nevada from the beginning of the Pleistocene, and indeed he divided the Pleistocene into two parts on the basis of the Sierra Nevada uplifts: the first dating from the initial uplift of the Sierra and the second from the final uplift. Thus, Lawson may have included in the Pleistocene a considerable period of time considered by Lindgren, Knopf, and Matthes to be within the Tertiary.

Lindgren (1911, p. 41-43) maintained that the present fault lines of the eastern escarpment of the Sierra Nevada "were in the main established" before the rhyolitic and andesitic eruptions and that they were in existence at the time of deposition of the auriferous gravels. However, he recognized that faulting and uplift occurred after the close of the rhyolitic eruptions and during the andesitic eruptions of late Tertiary time. Lindgren (1911, p. 41) and others after him (for example, Knopf and Matthes) believed that the recent dislocation along the eastern escarpment of the Sierra Nevada "consists in a sinking of the eastern blocks." The rhyolite tuff to which Lindgren referred was deposited on bench gravels of the Yuba River that he regarded as Miocene(?) in age on the basis of fossil leaves. Following an interval of erosion, the debris that became andesitic tuffs and breccias flowed from volcanoes along the Sierra Nevada summit down the river valleys. The rhyolitic tuffs are now termed the Valley Springs formation, and the andesites are called the Mehrten formation in the Sierra Nevada (Axelrod, 1957). Both are considered by Axelrod to be "MioPliocene" in age. Lindgren regarded the upbuilding of the Sierra Nevada as one of repeated rejuvenation along eastern fault lines of great antiquity.

Knopf (1918, p. 82-84) showed that the contact between the granitoid rocks of the Sierra Nevada and the roof pendants is a surface of very great relief; the sedimentary roof pendant at Table Mountain, between the Middle and South Forks of Bishop Creek, for example, projects at least 2,500 feet downward into the granite. Knopf (1918, p. 83) therefore rejected Lawson's hypothesis that the Summit Upland is, in the words of 
Knopf, "a surface of differential degradation controlled by the gently undulating contact surface of the granite batholith with the rocks that formerly extended over it." The Summit Upland is, then, only the unreduced interstream portion of the ancient erosion surface represented by the Subsummit Plateau; the two surfaces are continuous parts of a high mountain zone, and they were formed during the same period of erosion.

Knopf (1918, p. 83-86) adopted the High Valley zone of Lawson (fig. 3, this report) and related it to the period of erosion following the initial Tertiary uplift of the Sierra Nevada. This uplift of about 2,500 feet may, according to Knopf, be as recent as early Pliocene or as early as late Eocene. Because east-flowing streams that evolved a mature topography are found stranded high upon the eastern fault escarpment of the Sierra Nevada, Knopf (1918, p. 88) assumed that this initial disturbance was epeirogenic in nature and not accompanied by relative subsidence of the Owens Valley block. The present canyons were cut into the High Valley zone following uplift of the Sierra Nevada to its present heights in early Pleistocene, accompanied by relative subsidence of the Owens Valley block to the east. A period of stability separated the two Sierra uplifts.

Knopf (1918, p. 88) wrote in summary:

For the facts established by Lindgren in his study of the Tertiary auriferous-gravel epoch show that the drainage was rejuvenated at the close of the rhyolitic eruptions, probably late in the Miocene. This date Lindgren believes is more in harmony with the length of time indicated by the great erosional work performed since the uplift; it assuredly does less violence to our ideas concerning the length of Quaternary time than does the assignment of a post-Pliocene age to the initial uplift and to the westward tilting of the range.

The evidence from measurements of gravity of tremendous accumulations of clastic debris in Owens Valley and of prolonged continuous or repeated fault movement along the bounding faults supports Knopf's conclusion.

In his study of the geologic history of the Yosemite Valley area, Matthes (1930, p. 27-31) outlined in greater detail than his predecessors the probable history of the rise of the Sierra Nevada. Recognizing that faulting along the eastern escarpment of the Sierra may have begun as early as the end of Cretaceous time, Matthes thought it more likely that the structures to the east were blocked out by faulting during the second half of Tertiary time and that the earlier movements were gradual upwarpings.

Matthes (1930, p. 31-45) found evidence of three episodes of uplift in three stages of canyon cutting by Merced River and in a correlation of hanging valleys that discharge their waters into the Merced River from two different levels. The erosion surfaces in the canyon of the Merced River studied by Matthes are similar to those in the Upper Kern River basin described by Lawson.

The highest and oldest of these episodes is the mature Broad Valley stage (fig. 4), which dates from a gradual upwarping in early Eocene time that continued intermittently to the end of the Eocene and was followed by quiescence through Oligocene and the first half of Miocene times. The Broad Valley, therefore, is virtually a late Miocene surface where it has not been modified by glacial sculpture, although, as Axelrod (1957) pointed out, it or any other exposed surface is in reality a modern surface; the Broad Valley surface has been subjected to some modification by erosion later than the Miocene. A high system of hanging valleys is stranded above the Merced River at the Broad Valley level.

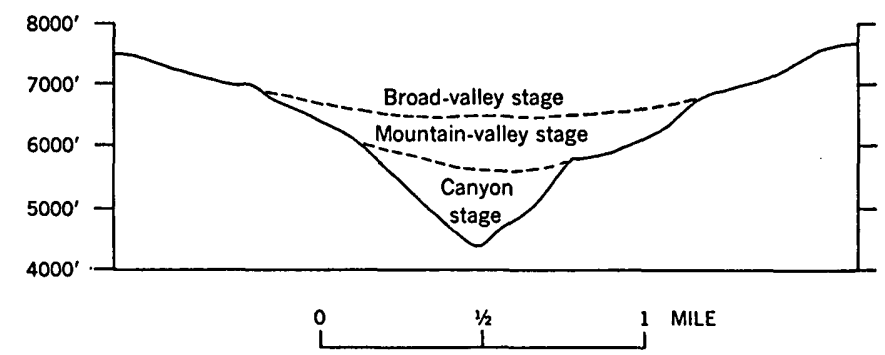

Frodri 4.-Erosion surfaces of Yosemite Valley area (after Matthes, 1930).

The surface of the Mountain Valley stage is incised into the Broad Valley surface; it may be correlated with the High Valley zone of Lawson. During the second half of Miocene time, the Mountain Valley surface was eroded to smoothly rounded slopes following a major uplift, accompanied by intensive faulting along the eastern margin of the Sierra Nevada. A quiescent interlude followed through Pliocene time; so, the surface of the Mountain Valley stage is virtually late Pliocene in age. Another system of hanging valleys at the Mountain Valley level was identified by Matthes.

Finally, the Sierra Nevada was uplifted to its present height in early Pleistocene time; the uplift was accompanied by great faulting to the east. The youthful canyons of the Canyon stage were deeply incised into the older Mountain Valley surface following this uplift to give the present surface. Glacial sculpture has greatly augmented stream action in producing the present scenery of Yosemite Valley. The Canyon stages of Matthes and Lawson are presumably the same.

The late Miocene uplift raised the crest of the Sierra Nevada 3,000 feet according to Matthes; the final, early Pleistocene uplift elevated the crest to its present height. Mount Lyell in the Yosemite Valley area, which is now 
about 13,000 feet above mean sea level, was at an altitude of about 4,000 feet during the Broad. Valley stage.

Later Matthes (1933, p. 38), citing the faulting of McGee moraines as evidence of downfaulting of the Owens Valley block, believed that the "features of the eastern escarpment of the Sierra Nevada are nearly all of Quaternary age." Matthes (1947) concluded that the final Sierra Nevada uplift came at the end of Pliocene time and carried up with it the area to the east. It was not until after the first ice age that faulting began, Owens Valley sank, and the great eastern scarp of the Sierra Nevada was formed by successive dislocations along the bounding faults. Thus, on the basis of glacial evidence, Matthes brought his views into accord with ideas expressed earlier by Lindgren and Knopf. However, the western bounding fault of the deep central wedge of Owens Valley is not everywhere coincident with the eastern bounding fault of the Sierra; so, subsidence of this part of the Owens Valley block may have begun before the latest uplift of the Sierra Nevada. Also, in the paper of 1947, Matthes revised his determination of the initial uplift of the Sierra Nevada toward the Recent, changing it from the last half of the Miocene to the end of the Miocene or the beginning of the Pliocene. Although he recognized the possibility that faulting may have accentuated the ruggedness of the eastern slope, he believed that the main movement was an asymmetric upward bowing of the Sierra Nevada, resulting in a short, steep eastern slope and a long gentle western slope.

\section{PALEOBOTANIC EVIDENCE}

Axelrod (1957) rejected the ideas of Lindgren and Matthes on the initial Tertiary uplift of the Sierra Nevada and concluded, on the basis of his study of "Mio-Pliocene" flora, that the Sierra was a broad ridge with a summit at about 3,000 feet above mean sea level just before the late Tertiary volcanism. Referring to the Broad Valley erosion surface of Matthes, Axelrod (1957, p. 21) wrote:

Some geologists have expressed skepticism that the upland surface in the Yosemite area corresponds to that on which the Mehrten formation was deposited. They point out that there is no evidence that the Yosemite area was covered by andesite, and hence the erosion surface may have been developing since Miocene time, or earlier; in any event, the present surface is of later Cenozoic, not of Mio-Pliocene age, for it is not covered by volcanics. Others have examined the region and doubt that there is an old erosion surface, at least in Matthes' sense.

Although it may be doubted that the Broad Valley surface was formed following an Eocene upwarping of the Sierra Nevada, as Matthes maintained, it is on the Mountain Valley and Canyon stages that Matthes based his conclusions on the post-Eocene Sierra uplifts.
His observations on these surfaces are supported by the earlier studies of Lawson, the observations of Knopf, and Baker's (1912) correlation of the Ricardo erosion surface of the Mojave region with the Chagoopa Plateau in the basin of the Upper Kern River.

Axelrod (1957, p. 21) evidently misunderstood the bases of Matthes' conclusions on the uplift of the Sierra, for he wrote: "His [Matthes'] estimate of 3,000 feet uplift at the close of the Miocene apparently was derived from the work on the Truckee quadrangle which led Lindgren $* * *$ to believe that there was major preandesite faulting in the region." Matthes actually deduced this uplift on the basis of the surface of the Mountain Valley stage and the hanging valleys of this and the Broad Valley stage. Further, Axelrod (1957, p. 21) misinterpreted Matthes' ideas concerning faulting when he noted that "Matthes cited no facts in support of MioPliocene faulting in the Yosemite area. Actually, no such evidence exists there, for the rocks in the uplands are pre-Tertiary crystallines and provide no data for estimating the amount of faulting at any time in the Tertiary." Matthes (1930) discussed the coincidence of uplift of the Sierra Nevada with faulting along the eastern front of the range well to the east of Yosemite Valley, and later he (Matthes, 1947) minimized the importance of faulting during the late Miocene or early Pliocene uplift. Thus Axelrod's (1957, p. 21) conclusion that "the method by which his [Matthes'] conclusion was reached is unsound" seems unjustified.

Axelrod (1957) studied both the effect of altitude on more than 20 "Mio-Pliocene" floras that were living just before or during the early eruptions of the late Tertiary andesites (Mehrten formation) and the influence of the Sierra Nevada as a climatic barrier. He concluded that the Sierra was a broad ridge having a summit about 3,000 feet above sea level just before these eruptions and that it was incised by valleys 2-4 miles wide and about 1,000 feet deep, some of which drained western Nevada. The lowlands of western Nevada had an average altitude of 2,000-3,000 feet above sea level. Fault deformation began in late Pliocene or early Pleistocene time, and uplift increased southward. The total uplift in the Donner Pass area was about 5,300 feet; it was about 6,500 feet at Carson Pass just south of Lake Tahoe.

About 3,000 feet of andesite was piled on top of the Sierra ridge by the close of early Pliocene time. The initial uplift of the Sierra Nevada is commonly assumed to have taken place during and probably immediately following this episode of volcanism. However, Axelrod found that floras to the lee of the Sierra Nevada did not reflect the lower amount of precipitation relative to the windward slopes expected from the creation of such a climatic barrier. Axelrod (1957, p. 42) concluded: 
This probably was because the crust could not support the volcanics on the Sierra Nevada and adjacent Nevada. To maintain isostatic balance, the basement would have to sink and displace a mass of sima equal to the added volcanics. Since an andesite blanket 3,000 feet thick would have to subside approximately four-fifths to come into equilibrium, the surface would be only about 500 feet higher than before vulcanism.

Evidence from gravity measurements in the Sierra Nevada (Oliver, 1956) and the Basin Ranges (D. R. Mabey, written commun., 1956) and from this study clearly shows that, generally, topographic masses are only regionally compensated isostatically. Therefore, residual relief exceeding an equivalent uplift of 500 feet would probably remain after the andesite eruptions, and at least some high peaks were possibly built up by these eruptions, even though some subsidence (with faulting along the eastern border of the Sierra Nevada) may have accompanied withdrawal of magma from beneath the area. If the andesite came from within the zone of isostatic compensation, the eruptions would have brought about no net disturbance of the isostatic equilibrium but rather a redistribution of the crustal load by piling the andesite high above the preeruption surface in some places.

Axelrod (1957, p. 42) concluded:

It was only in post-middle Pliocene time, largely in the late Pliocene to middle Pleistocene interval, that warping and faulting increased the altitude of the Sierran crest line from 5,000 to 6,000 feet in this north-central section. The effects of warping and faulting increased southward, and 100 to 150 miles away maximum uplift was approximately 7,500-9,000 feet.

Axelrod acknowledged that there is "some evidence that the range gradually decreased in altitude northward in Mio-Pliocene time ***." Hinds (1956), also basing his conclusions on paleobotanic evidence, wrote:

Later in the Miocene and early Pliocene, a long, dominantly explosive volcanic episode covered large sections of the northern half of the range with mudflows. Considerable elevation, possibly doming of a greater area than the Sierra Nevada itself, occurred during and following this cycle, allowing erosion of canyons 1,200 to 1,500 feet deep. During the late Pliocene, the major elevation of the Sierra Nevada occurred, and greatly invigorated streams started erosion of the canyons of the present cycle.

Noting that "dislocation of McGee moraines on the east side of the Sierra Nevada shows that graben subsidence of at least 3,000 feet followed the first glacial age and is still continuing * * *, Hinds (1956) seemed to reach conclusions in virtually complete accord with those of Matthes in his later years.

Although the geophysical data suggest to us that the deepest wedge of the Owens Valley graben, which is structurally removed from the Sierra Nevada, could have been blocked out by faults well before the end of Tertiary time, we find little evidence in the litera- ture, our own field observations, or the gravity data to refute Matthes' work.

Many other geologists have contributed to our knowledge of the Sierra Nevada-Owens Valley region, and they will be considered with the analysis of the geophysical data. Finally, Hudson (1955) deduced a middle Eocene altitude of 5,500 feet above sea level for the Sierra Nevada summit in the Donner Pass area on the basis of the gradients of the Tertiary Yuba River. Therefore, the late Tertiary uplift of the Sierra Nevada was only about 2,000 feet in the Donner Pass area. Hudson and Axelrod seem to agree on the history of the Sierra Nevada uplift; they differ on its magnitude.

\section{GEOPHYSICAL SURVEYS}

The earth at an early stage in its history was divided by some process of differentiation into its major units: the crust, the mantle, and the core (Mason, 1952, p. 5357). Each of these units has its characteristic density, seismic velocity, and other physical properties (Birch, 1952). Had the earth remained undeformed at the end of its original differentiation, the density and velocity layering would now be concentric. The gravity field as measured at the surface would vary uniformly with latitude, according to the International Gravity Formula (Nettleton, 1940, p. 137), and would yield information only on the shape of the earth and its angular velocity. Seismic traveltime curves would be everywhere the same. The magnetic field would also be monotonously smooth.

But the earth has not remained undeformed. As a result of the application of internal forces, rocks of contrasting densities, seismic velocities, and magnetic susceptibilities (and other physical properties) have been moved into irregular and complex juxtaposition by faulting, folding, igneous activity, water, wind, and ice, and simply by sliding or rolling down slopes that were formed by these same internal forces. As a result, the gravity field is highly irregular, the paths of seismic waves are complex and variable, and the magnetic field is seemingly erratic. The geophysical anomalies thus created can be measured. Because they follow wellestablished physical laws and because they are controlled by the nature of the geologic deformation, these anomalies can be interpreted to reveal important information on the subsurface geologic structure. In addition they may provide some clues as to the processes and forces that brought about the rock movements that in turn caused the anomalies to come into existence.

In the Owens Valley region, we are concerned with the following kinematic processes: the displacement of lighter against heavier rocks by faulting; the erosion, transport, and deposition of rock particles by water, 
STRUCTURAL GEOLOGY AND VOLCANISM, OWENS VALLEY, CALIF.

wind, and ice; and the movement of magma from great depths to the surface by volcanic activity. These kinematic processes have brought about lateral inhomogeneities in density, seismic velocity, and magnetic susceptibility; we can therefore study their effects by gravity, seismic, and magnetic surveys.

The movement of rock materials by these kinematic processes in the Owens Valley area has been confined for the most part to the area, for no natural outlet to the sea exists and, through much of its history, Owens River has not flowed beyond the southern limit of Owens Valley. Therefore, the Owens Valley area can be regarded as a closed system in that little rock material has been brought in and relatively little has been carried out of the area. The total mass of rock material involved in the very great deformation in the Owens Valley area has therefore remained roughly constant. The geologic structures and processes of the area are particularly appropriate for study by geophysical methods.

\section{GRAVITY SURVEY}

The density of the light deposits of Cenozoic age that fill the valleys and basins is considerably less than that of the pre-Tertiary rocks that lie buried beneath these lighter deposits and that rise above the valleys to form the main masses of the mountain ranges. Therefore, thick accumulations of Cenozoic deposits should be expressed by pronounced gravity lows; and zones of steep gravity gradients may suggest something about the inclination of the interface between the Cenozoic deposits and pre-Tertiary rocks.

\section{DENSITX}

Densities of the pre-Tertiary plutonic and metamorphic rocks in the Owens Valley area are known with considerable accuracy. Densities of the Cenozoic clastic and volcanic rocks are highly variable and are much less reliably known. However, available seismic-refraction information on depths to the pre-Tertiary bedrock floor makes it possible to place the average density of the complete Cenozoic section along common gravity and seismic profiles within a fairly narrow range of values. Although we collected rock samples only in the Long Valley area; the measured densities of the preTertiary rocks there can be assumed for the entire Owens Valley area. Densities of samples of the Cenozoic deposits collected at the surface have little significance in gravity interpretation; the densities computed from a comparison of the seismic and gravity data are much more meaningful, and we will place our confidence on these. William Huff of the U.S. Geological Survey made the measurements of density on the rock samples from the Long Valley area.
Measured densities of 10 dry samples of the plutonic rocks range from 2.42 to $2.69 \mathrm{~g}$ per $\mathrm{cm}^{3}$; the average density of these samples is $2.60 \mathrm{~g} \mathrm{per} \mathrm{cm}^{3}$. If two samples of low density are omitted, the average density of the plutonic rocks becomes $2.63 \mathrm{~g} \mathrm{per} \mathrm{cm}^{3}$. Measured densities of nine dry samples of metamorphic rocks range from 2.63 to $2.94 \mathrm{~g}$ per $\mathrm{cm}^{3}$, and their average density is $2.78 \mathrm{~g}$ per $\mathrm{cm}^{3}$. A representative density of $2.7 \mathrm{~g}$ per $\mathrm{cm}^{3}$ is assigned to saturated pre-Tertiary rocks for purposes of interpretation. This density agrees closely with that determined by Howard Oliver (written communication, 1959) in his gravity study of the Sierra Nevada and with published data on rock densities. (See, for example, Birch and others, 1942, p. 14; Heiland, 1940 , p. 80-81.) The contrast in average density of nearly $0.2 \mathrm{~g} \mathrm{per} \mathrm{cm}^{3}$ between the plutonic and metamorphic rocks may have some influence on the gravity field.

It is exceedingly difficult to determine a reliable average density for the Cenozoic deposits because of their extreme heterogeneity; the densities of samples collected at the surface can be misleading. Twenty-two samples of Cenozoic rocks (excluding basalt) collected in the Long Valley area range in density from a minimum of 1.36 for the Bishop tuff of Gilbert (1938) to a maximum of $2.37 \mathrm{~g}$ per $\mathrm{cm}^{3}$ for coarse lake beds. Six basalt samples range in density from 2.59 to $2.73 \mathrm{~g}$ per $\mathrm{cm}^{3}$ and their average density is $2.66 \mathrm{~g}$ per $\mathrm{cm}^{3}$. Gilbert (1938) found that the Bishop tuff ranges uniformly in density from $1.3 \mathrm{~g} \mathrm{per} \mathrm{cm}^{3}$ at the surface to $2.32 \mathrm{~g}$ per $\mathrm{cm}^{3}$ at a vertical distance of about 400 feet below the top of the tuff.

The rocks of Cenozoic age that fill the depressions in the Owens Valley area are known to include alluvial deposits, lake beds, glacial till, and a wide assortment of volcanic deposits; these rocks range in density from less than 1 for pumice to at least $2.73 \mathrm{~g}$ per $\mathrm{cm}^{3}$ for basalt.

An average density of 2.2 or $2.3 \mathrm{~g} \mathrm{per} \mathrm{cm}^{3}$ is assigned to the Cenozoic deposits for purposes of interpretation. Use of this average density for computations yields determinations of depths to the pre-Tertiary rocks that agree closely with those obtained from the seismicrefraction results, and this average density is known to agree closely with the average density determined by a combination of seismic and gravity methods by the Shell Oil Co. in Railroad Valley, Nev. (R. J. Bean, written commun., 1958). D. R. Mabey (written commun., 1958) determined a similar average density after extensive sampling of the deposits of Cenozoic age in the Mojave Desert and the Death Valley regions of California. 
In the interpretation of the gravity data, therefore, a contrast in average density of -0.4 or $-0.5 \mathrm{~g}$ per $\mathrm{cm}^{3}$ is assumed to exist between the Cenozoic deposits and the pre-Teritary rocks. (See Pakiser and others, 1960.) However, the density contrast is acknowledged to be possibly as much as $-0.6 \mathrm{~g}$ per $\mathrm{cm}^{3}$ or as little as -0.3 ; true depths (determined in the absence of seismic confirmation), therefore, may range from about 70 to 130 percent of those computed from the gravity data. Despite this wide range of possible depths, determinations of the configuration of the Cenozoic structures in the Owens Valley area from the gravity data remain the same. Lateral variations of density within the Cenozoic section may, however, affect the gravity field.

For a more detailed discussion of the problem of the density of valley-fill sediments, see Kane and Pakiser (1961).

\section{FIELDWORK AND COMPUTATIONS}

A total of 1,550 gravity stations was established during five field periods: February 1954, July-August 1955, February-March 1956, July-August 1956, and July 1957. The fieldwork in the higher altitudes north of latitude $37^{\circ} 30^{\prime} \mathrm{N}$. was done during the summer to avoid snow; most of the work in Owens Valley was done during the winter to avoid the excessive summer heat.

The field party was made up usually of four men: the party chief and computer, the observer, the surveyor, and the rodman. Gravity stations were usually set along roads and jeep trails, but some traverses were made on foot where the need for more detail was indicated by the data. Measurements were extended into the mountain areas so that the regional gravity gradient could be determined.

Bench marks of the U.S. Geological Survey, the U.S. Coast and Geodetic Survey, the California State Highway Department, and the City of Los Angeles Department of Water and Power, and spot elevations on U.S. Geological Survey topographic maps were used as locations for about 55 percent of the stations. The remaining stations were surveyed by the field crews. Most of the surveying was done by using planetable and alidade, but a few stations requiring long hikes were set by using altimeters.

Sixteen base stations were established at easily accessible and relatively permanent locations. The locations were selected as the survey expanded and as new base stations were needed. At least three readings were made at each new base, and the average of the readings was used to determine the base value. All repeated readings at the base stations agreed within $0.2 \mathrm{mgal}$. Basestation data and descriptions are listed in table 1.
TABLE 1. Owens Valley project gravity bases

\begin{tabular}{|c|c|c|c|c|c|c|c|}
\hline Station & $\begin{array}{l}\text { Lat1- } \\
\text { tude } \\
\text { N. }\end{array}$ & $\begin{array}{l}\text { Longitude } \\
\text { w. }\end{array}$ & $\begin{array}{c}\text { Alti- } \\
\text { tude } \\
\text { (feet) }\end{array}$ & $\underset{\text { (mgal) }}{\text { Observed }}$ & $\begin{array}{c}\text { Free air } \\
\text { anomaly } \\
\text { (mgal) }\end{array}$ & $\begin{array}{l}\text { Bouguer } \\
\text { anomaly } \\
\text { (mgal) }\end{array}$ & $\begin{array}{l}\text { Complete } \\
\text { Bouguer } \\
\text { anomaly } \\
\text { (mgal) }\end{array}$ \\
\hline \multicolumn{8}{|c|}{ Inyo County } \\
\hline & 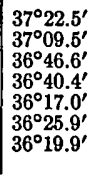 & $\begin{array}{l}118^{\circ} 23.6^{\prime} \\
118^{2} 17.3^{\prime} \\
118^{\circ} 10.7^{\prime} \\
118^{\circ} 05.7^{\prime} \\
118^{\circ} 00.3^{\prime} \\
117^{4} 49.4^{\prime} \\
117^{\circ} 42.8^{\prime}\end{array}$ & $\begin{array}{l}4,143 \\
4,009 \\
3,955 \\
3,788 \\
3,646 \\
3,796 \\
4,878\end{array}$ & $\begin{array}{l}979,462.88 \\
979,465.28 \\
979,465.00 \\
979,468.81 \\
979,420.60 \\
979,477.91 \\
979,406.06\end{array}$ & $\begin{array}{r}-96.99 \\
-88.36 \\
-60.65 \\
-68.32 \\
-91.58 \\
-32.93 \\
+5.61\end{array}$ & $\begin{array}{l}-238.14 \\
-224.95 \\
-195.40 \\
-195.67 \\
-215.80 \\
-162.26 \\
-160.58\end{array}$ & $\begin{array}{l}-233.64 \\
-217.55 \\
-189.63 \\
-189.70 \\
-208.48 \\
-158.39 \\
-159.04\end{array}$ \\
\hline \multicolumn{8}{|c|}{ Mono County } \\
\hline 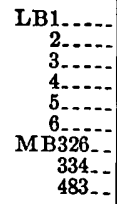 & $\begin{array}{l}37^{\circ} 35.2^{\prime} \\
37^{\circ} 38.8^{\prime} \\
37^{\circ} 42.0^{\prime} \\
37^{\circ} 39.4^{\prime} \\
37^{\circ} 38.0^{\prime} \\
37^{\circ} 00.6^{\prime} \\
37^{\circ} 55.5^{\prime} \\
37^{\circ} 9.4^{\prime} \\
38^{\circ} 09.7^{\prime}\end{array}$ & 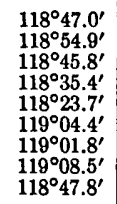 & $\begin{array}{l}6,920 \\
7,289 \\
6,817 \\
6,967 \\
4,527 \\
7,287 \\
6,461 \\
6,706 \\
7,083\end{array}$ & $\begin{array}{l}979,314.48 \\
979,278.80 \\
979,300.87 \\
979,353.65 \\
979,453.91 \\
979,322.51 \\
979,348.95 \\
979,382.94 \\
979,365.83\end{array}$ & $\begin{array}{r}-2.61 \\
-8.82 \\
-35.80 \\
+34.88 \\
-92.34 \\
+17.54 \\
-17.81 \\
-12.56 \\
+13.82\end{array}$ & $\begin{array}{l}-238.37 \\
-257.16 \\
-268.06 \\
-202.49 \\
-246.57 \\
-230.73 \\
-246.28 \\
-232.69 \\
-227.50\end{array}$ & $\begin{array}{l}-231.27 \\
-253.64 \\
-266.05 \\
-199.94 \\
-239.67 \\
-227.20 \\
-243.35 \\
-221.97 \\
-226.30\end{array}$ \\
\hline
\end{tabular}

1 Referred to U.S. Coast and Geodetic Survey "Independence" gravity pendulum station.

Terrain correction mado.

Coast and Geodetic Survey "Independence" gravity pendulum station.

B1. About 1.0 mile north of Blshop, Inyo County, along U.8. Highway 6 and 395 , about 0.2 mile north of junction of U.S. Highways 6 and 395 , on U.S. Highway 6 , at service station, $5 \mathrm{ft}$ west of U.S. Coast and Geodetic Survey bench mark tentified by a disk stamped "V-124 Reset 1945" and set in concrete base of the pump 1sland; on ground

B2. At south edge of Big Pine, Inyo County, on U.S. Highway 6 and 395 at southwest corner of intersection of the highway and Bartell Avenue, $4 \mathrm{ft}$ east of Californla Depart

B3. Abont U.S. 2.2 miles south of Independence, Inyo County, along U.S. Highway 6 and $395,150 \mathrm{ft}$ east of Callfornla Division of Highways marker $443+19$, at U.S. Coast and Geodetic Survey pendulum gravity sta.

B4. About 5.0 mile north of Lone Pine, Inyo County, along U.S. Highway 6 and 395 , north of bridge over splllway, near Callfornia Division of Highways station $480+85,50 \mathrm{ft}$ center line of highway; on ground

B5. At Olancha, Inyo County, at the northeast corner of the intersection of U.S. Highway, 395 and road to Darwin (east of Owens Lake), 2 ft south of fence corner; on ground.

B6. About 20 miles south of Lone Pine, Inyo County, along California State Highway 190, at intersection of highway and road to Olancha, at southwest corner of the inter-

B7. About 8.4 miles northwest of Darwln, Inso County, along road from Darwin to Lone Pine, on California State Highway 190 about $40 \mathrm{ft}$ south of road leading to Saline Valley near U.S. Coast and Geodetic Survey bench mark dentifed lava rock; on ground by the rock.

LB1. About 8.4 miles southeast of Casa Diablo Hot Springs, Mono County on U.S Highway 395 , at bridge orer McGee Creek near U's. Coast and Geodetic Survey bench mark identified by a disk stamped " $\mathrm{C}-124$ 1932" and set in the southwest corner of the bridge, on south shoulder of the highway 10 ft southeast of the disk; on ground.

LB2. At Casa Diablo Hot Springs, Mono County, $274 \mathrm{ft}$ southeast of the Casa Diablo store and $84 \mathrm{ft}$ east of the center line of the highway, near U.S. Coast and Geodetic Survey bench mark tentified by a disk stamped " $\mathrm{Z}-123$ 1932" and' set in concrete post; on ground by the post.

LB3. Along road between U.S. Highway 395 and California State Highway 120, Mono County, about 8.0 miles northeast of U.S. Highway 395, 6.9 mlles northeast of Whitmore Hot Sprting, 370 it east east concrete post; on ground by the post.

LB4. Along road between U.S. Highway 395 and Callfornia State Highway 120, Mono County, about 22.5 miles northeast of
U. S. Highway 395, 21.4 miles northeast of Whitmore Hot Springs, 72 ft north and $45 \mathrm{ft}$ east of road leading east, 41 ft north of road slgn near . U.S. Geol. Survey, bench mark concrete post : on ground by the post.

LB5. About 13.9 miles south of Benton Station, Mono County along U.S. Highway 6 , at the crossing of a power line and the intersection of a dirt road, $68 \mathrm{ft}$ west of the center line of the highway, near U.S. Coast and Geodetic Survey bench mark Identifled by a disk stamped "A-819 1955" and set in a concrete post; on ground by the post. 
TABLE 1.-Owens Valley project gravity bases-Continued

LB6. About 8.3 miles southeast of Lee Vining, Mono County, along U.S. Highway 395 , at junction of an old road leading southwest to June Lake, about $61 \mathrm{ft}$ west of the center line of the highway, near City of Los Angeles Department of Water and Power standard cap set in concrete post; on ground

MB326. b5 the post
bout 4.7 miles east along California State Highway 120 from the Intersection with U. S. Highway 395 . Mono County, on a curve at the foot of an east-sloping hill, $28 \mathrm{ft}$ south of the center lne of the highway, near o. S. Coast and "Q-204 1934" and set in a concrete post; on ground by the

MB334. At Mo

post. way 395 , in the parking lot north of the post office, at the approximate location of U.S. Coast and Geodetic Survey bench mark P-123 (destroyed by food), 25 feet north of the north wall of the post office, $7 \mathrm{ft}$ east of stone wall; on

MB483. 34 ground.

ground.
miles southwest of Hawthorne, Nev. along Nevada State Highway 31, (21.6 miles northeast of U.S. Highway 395 along pole line road which connects with Nevada State Houth vouth or the center line of "the highway, near Nevada surpost; on ground by the post.

A single-loop system was used in making the gravity measurements. The initial and final readings of a series ings is actually caused by a combination of meter drift to define the meter drift. The difference in base readdifference between the two base readings was assumed of measurements were made at a base station, and the and tidal variations, but in practice the difference is treated as if it were a linear variation with a single cause. Each series of readings contained a reading at a station that had been set earlier in the same loop and a reading at a station that had been set in a previous loop. The first repeat reading was used to check (but not control) the meter drift; the latter served as a check on the accuracy. Differences for both types of repeat readings have been compiled on histograms (fig. 5).

The gravity measurements were adjusted for linear instrument drift and were referred to the U.S. Coast and Geodetic Survey gravity-pendulum station at Independence (Duerksen, 1949). Later ties to the base network showed this network to be within $1 \mathrm{mgal}$ of Woollard's (1958) airport-base network. Corrections for latitude and altitude were made using procedures outlined in standard geophysics texts (Nettleton, 1940, p. 51-62). The corrections were made during the fieldwork in order to examine the progress of the survey. The drift curves were plotted daily. Terrain corrections were made later using the method outlined by Swick (1942, p. 67-68). The terrain corrections were extended through zone "O" of this system which corresponds to a radial distance of about 100 miles outward from the gravity station. A density of $2.67 \mathrm{~g}$ per $\mathrm{cm}^{3}$ was used for the altitude and terrain corrections. This density is representative of the pre-Tertiary rocks of the area in which the greatest range in altitude is found.

One thousand milligals were added to the complete Bouguer gravity so that the final values on the map (pl. 1) are positive. The complete Bouguer gravity with respect to the International Ellipsoid may be readily obtained by subtracting 1,000 from the contour values.
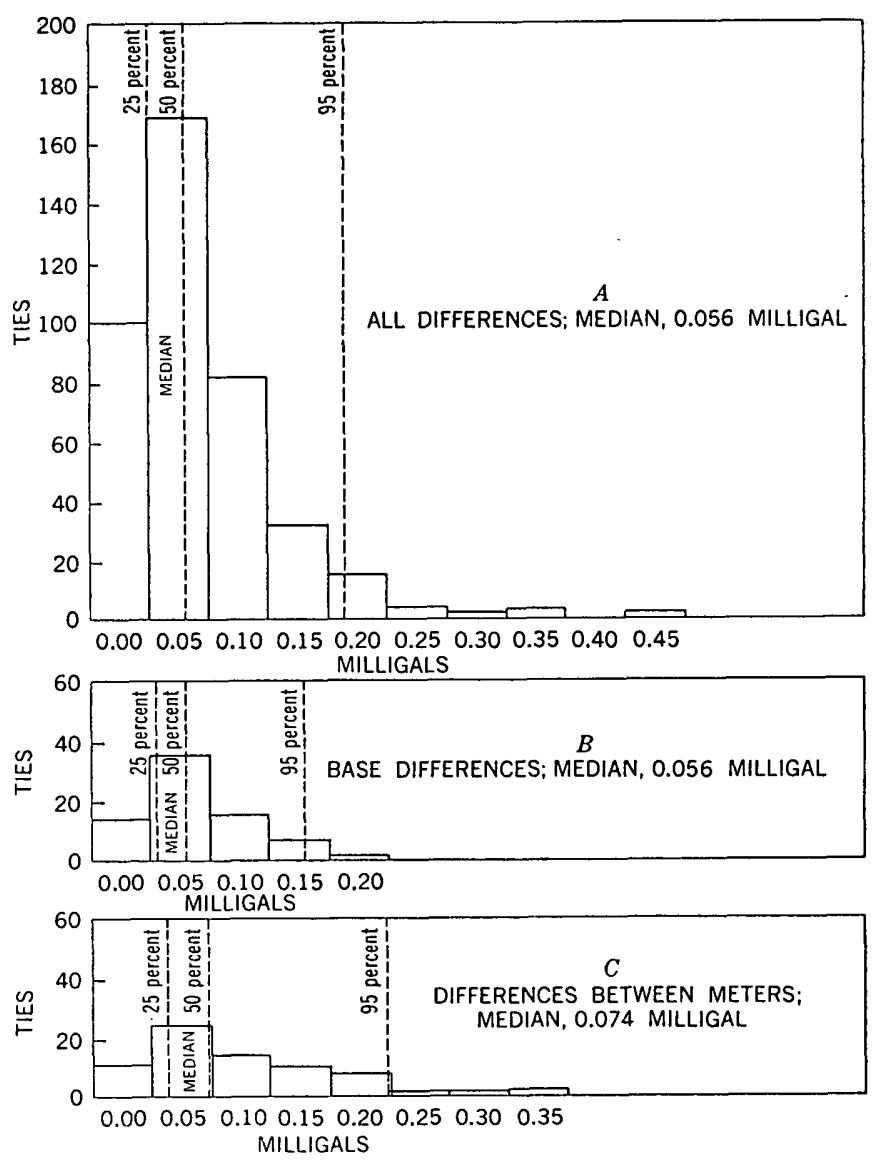

FIGURE 5.-Histograms showing accuracy of gravity data.

The gravity meters listed as follows were used in the survey:

\begin{tabular}{|c|c|c|}
\hline Gravity meter & Period used & $\underset{\text { Mgal/dision }}{\text { Mgal }}$ \\
\hline Frost_-_- & Winter $1954 \ldots$ & \multirow{6}{*}{$\begin{array}{r}0.0729 \\
.5046 \\
.5046 \\
.5045 \\
.2453 \\
.4720 \\
.5533\end{array}$} \\
\hline Worden & $-\alpha^{-1}$ do & \\
\hline $\begin{array}{l}\text { Do.. } \\
\text { Do_. }\end{array}$ & $\begin{array}{l}\text { Summer } 1955 \ldots \\
\text { Winter } 1956\end{array}$ & \\
\hline Worden 186 & Summer 1956 & \\
\hline $\begin{array}{l}\text { Worden 226-- } \\
\text { Worden 177.- }\end{array}$ & Summer 1957 & \\
\hline worden 18t & summer 1900 & \\
\hline
\end{tabular}

ACCURACY OF DATA

The histograms (fig. 5) are based on the differences without respect to sign of the values between original readings at a station and repeat readings. Histogram $A$ is based on all the differences and includes 412 repeat readings made with 5 different instruments, 11 different operators, and a time span of 5 years. The ties make up 20 percent of all gravity measurements, and this percentage is sufficient for determination of overall accuracy. The median difference, $0.056 \mathrm{mgal}$ (milligal), is the probable error of any single measurement in the sense that 50 percent of the measurements 
may be repeated with a probable difference of less than $0.056 \mathrm{mgal}$ and 50 percent with a probable difference greater than $0.056 \mathrm{mgal}$. Twenty-five percent of the differences are within $0.025 \mathrm{mgal}, 50$ percent within $0.056 \mathrm{mgal}$, and 95 percent within $0.190 \mathrm{mgal}$. All differences are within $0.450 \mathrm{mgal}$.

Histogram $B$ is based on 71 differences determined at base stations. The median difference, or probable error of any single measurement, is also $0.056 \mathrm{mgal}$. Twenty-five percent of the differences are within 0.030 mgal, 50 percent within $0.056 \mathrm{mgal}$, and 95 percent within $0.154 \mathrm{mgal}$. All base-station differences are within $0.20 \mathrm{mgal}$, which reflects the greater accuracy of base measurements.

Histogram $C$ is made up of 70 differences that were determined by different meters; that is, the meter used in the repeat reading was different from the meter used in the original reading. The median, $0.074 \mathrm{mgal}$, is greater than those of the two previous groups. Twentyfive percent of the differences agree within $0.039 \mathrm{mgal}$, 50 percent within $0.074 \mathrm{mgal}$, and 95 percent within $0.223 \mathrm{mgal}$. The apparent decrease in accuracy is related to the different meter constants, which are accurate within 1 part in 2,000. The decrease is small, and all differences in this group are within $0.35 \mathrm{mgal}$; the data from all the instruments, therefore, may be combined.

U.S. Geological Survey topographic maps provided the control for the horizontal position of the gravity stations. Fifteen-minute quadrangle maps were used for about 75 percent of the area, and 30-minute quadrangle maps were used for the remainder, which was chiefly in Mono Basin and northern White Mountains. Positions on these maps are accurate generally to within 100 feet and 500 feet, respectively. Gravity stations that were not at identifiable points such as road intersections, section corners, and bench marks were surveyed with horizontal closures of less than 500 feet. The gravity variation corresponding to 500 feet in horizontal position is $0.12 \mathrm{mgal}$.

The sources of vertical control were bench marks, spot altitudes on maps, lake levels, and surveyed altitudes. Bench-mark altitudes are accurate to within 1 foot, and spot altitudes and lake levels are accurate to within onetenth of a contour interval for steep slopes or to less than one-tenth for gentle slopes. Surveyed lines were closed within 4 feet in the valleys and within 8 feet in the mountain canyons. About 80 percent of the stations are in the valleys and therefore have altitudes that are accurate generally to within 4 feet. The remaining 20 percent of the stations are in mountain canyons and have altitudes accurate to within 8 feet. The gravity varia- tions corresponding to 4 feet and 8 feet in altitude are 0.24 and $0.48 \mathrm{mgal}$, respectively.

The accuracy of a terrain correction is difficult to estimate because the correction consists of a series of approximations. The Owens Valley terrain corrections are reproducible to within 10 percent of the original and are internally consistent (that is, no erratic differences are evident between stations). The total error is probably within 10 percent of the correction, which gives accuracies of $\pm 1.0 \mathrm{mgal}$ in the valleys and \pm 2.5 mgals in the mountains. The relative error for adjacent stations is probably less.

Altimeter altitudes were used for seven stations in the Owens Lake area and for a like number of stations in Mono Basin. The altimeter altitudes have estimated accuracies of \pm 20 feet, which corresponds to a gravity error of $1.2 \mathrm{mgals}$. A group of four stations was set along the crest of the northern White Mountains using altitudes that have a possible error of \pm 100 feet. $\mathbf{A}$ fifth station, which was set on White Mountain Peak at a bench mark, has a terrain correction of $79 \mathrm{mgals}$. Together, the five stations have possible gravity errors of about \pm 5 or \pm 10 mgals. The three groups of stations are in areas where the determined gravity values are useful despite the relatively large possible errors. The stations of these groups are not considered in the following table of possible errors.

\begin{tabular}{|c|c|c|}
\hline \multirow{2}{*}{ Source } & \multicolumn{2}{|c|}{ Error (mgal) } \\
\hline & Valleys & Mountains \\
\hline $\begin{array}{l}\text { Observation } \\
\text { Position } \\
\text { Altitude } \\
\text { Terrain }\end{array}$ & $\begin{array}{r} \pm 0.10 \\
\pm .12 \\
\pm .24 \\
\pm 1.00\end{array}$ & $\begin{array}{r} \pm 0.10 \\
\pm .12 \\
\pm .48 \\
\pm 2.50\end{array}$ \\
\hline
\end{tabular}

In the foregoing table the following may be noted: (1) The errors may be independently plus or minus, and a cumulative error therefore, is unlikely; (2) the maximum altitude error is two to four times the observation or position error, and the accuracy of gravity values without terrain corrections, therefore, is most probably controlled by altitude accuracy, (3) the terrain correction error is by far the largest and controls the accuracy of the final gravity value.

\section{INTERPRETATION OF GRAVITY DATA}

In this study, the interpretation of the gravity data was done in the following order:

1. A qualitative study was made of the gravity contour maps (pl. 1) to reach broad, general conclusions on the subsurface configuration of the interface between the Cenozoic deposits and the pre-Tertiary rocks. The gravity field represented by the 
gravity contours was assumed to be a true representation of the gravity field on the surface of the ground, corrected for effects of altitude, latitude, and terrain. This assumption is probably correct over most of the area, but in places where the ground altitude increases locally in materials of lower density than that assumed for the altitude corrections, the relative gravity field may be slightly higher than that shown on the maps.

2. Selected gravity profiles were analyzed by measuring the solid angle subtended from a position on the surface of the ground by a sequence of slabs of low-density Cenozoic material that could then be assembled to represent the configuration of the Cenozoic and pre-Tertiary interface. The gravity anomaly at any location was determined by multiplying the total solid angle subtended by all slabs at that location by a constant factor that depends on the assumed density contrast and the thickness of each slab. The elongated features of Owens Valley were assumed to extend without limit along their axes, and a two-dimensional graticule was used to determine their gravity effect. The solid angles for the more nearly equidimensional structural features of Long Valley and Mono Basin were measured using a solid-angle chart.

3. The theoretical gravity anomalies determined from the measurements of the solid angles were then compared to the real anomalies taken from profiles on the gravity contour maps, and the assumed configurations were modified, if necessary, until a satisfactory agreement between the anomalies was obtained.

\section{GRAVITY CONTOUR MAPS}

Inspection of the gravity contour maps (pl. 1) establishes that the gravity field tends to be relatively low in the valleys and basins, where low-density rocks of Cenozoic age are exposed, and relatively high in the ranges, where denser pre-Tertiary rocks crop out. The amplitude of negative departure of the gravity field in areas of outcrop of Cenozoic rocks from the higher gravity where pre-Tertiary rocks are exposed is a guide to the thickness of the Cenozoic rocks. The magnitude of the steepest gradients along or near contacts between Cenozoic and pre-Tertiary rocks is a guide to the steepness of the subsurface interface between these rocks. Where the gradients are very steep, it may be inferred that the Cenozoic and pre-Tertiary rocks are in fault contact. An erosional or warped surface or distributive faulting may be inferred where the gradients are gentle.

In a general way, Owens Valley is characterized by a narrow, nearly linear gravity low that extends along the entire length of the valley. However, more detailed examination shows that many interesting local features in the gravity field suggest considerable geologic complexity. Long Valley and Mono Basin are strikingly different in their gravity expressions from Owens Valley. The gravity anomalies associated with these two features are much more nearly equidimensional in plan, the gravity gradients that bound them are steeper, and the residual gravity relief of each is greater than that of Owens Valley. Some smaller features, such as Adobe Valley and the area southeast of Lake Crowley covered by the Bishop tuff of Gilbert, are clearly revealed by the gravity contours.

The area north of lat $37^{\circ} 45^{\prime} \mathrm{N}$. has been previously described in detail (Pakiser and others, 1960), and this description is summarized briefly here. The area south of lat $36^{\circ} 50^{\prime} \mathrm{N}$. has also been previously described (Kane and Pakiser, 1961). In the discussion that follows, each of the four sections of the gravity survey (pl. 1 ) is discussed separately (proceeding from north to south) for convenience and for an orderly presentation of the gravity data.

AREA NORTH OF OWENS VALLEY

The area studied north of Owens Valley extends from lat $37^{\circ} 30^{\prime}$ to $38^{\circ} 05^{\prime}$ and from long $118^{\circ} 10^{\prime}$ to $119^{\circ} 15^{\prime}$ (pl. 1, sheet 1). It includes the slopes of the Sierra Nevada, Long Valley, Mono Basin, the northern extension of the Owens Valley structure, the northern White Mountains, and several smaller basin and range structural features. It is an area having a history of diverse and violent volcanism, great structural complexity, and structural trends that are seemingly at odds with the simpler trend of Owens Valley. It is an area which also includes the largest offset of the eastern front of the Sierra Nevada.

The geology on the map (pl. 1, sheet 1) was compiled from the following sources: Anderson (1937), in and immediately west of the northern White Mountains; Gilbert (1941), north of Long Valley and southeast of Mono Lake; and Rinehart and Ross (1957; written commun., 1958), in the Long Valley area. The geology north and west of Mono Lake is based on a brief reconnaissance by Pakiser.

The most dominant gravity features in the area north of Owens Valley are the broad gravity lows in Long Valley and Mono Basin and the narrow north-trending gravity low west of the front of the White Mountains. The broad gravity low roughly outlining the shoreline of Mono Lake has a residual gravity relief of about 50 mgals, and the steepest gravity gradients on the southwest and northwest sides of this anomaly have a maximum magnitude of 15 mgals per mile. The Mono Basin anomaly has been interpreted as the expression of a large, triangular block that subsided along near-vertical 
faults and received an accumulation of $18,000 \pm 5,000$ feet of light clastic and volcanic rocks of Cenozoic age (Pakiser and others, 1960). The gravity data were used to deduce a thickness of more than 2,000 feet for Cenozoic deposits in Adobe Valley. The two nearly circular gravity highs (and coincident magnetic anomalies) were interpreted as probably the expressions of volcanic necks. The weak gravity high near the center of Mono Lake, together with a magnetic high at the same place, was interpreted as the expression of a pile of intrusive and extrusive volcanic rocks (Pakiser and others, 1960).

The large, elliptical gravity low in the Long Valley area (south of the Glass Mountain Ridge and north and east of the Sierra Nevada) is by far the most dominant gravity feature in the entire Owens Valley region. The anomaly has an area inside the zone of steepest gradients of about 150 square miles. The largest gravity relief (without correction for the regional gradient) between the highest contour in the Benton Range to the east and the lowest contour of the anomaly is $78 \mathrm{mgals}$ in a distance of only 13 miles; this is the largest local difference in gravity yet reported in the Great Basin. The steepest gravity gradient on the eastern end of this anomaly is 20 mgals per mile. By making a simple computation using the expression for the gravity attraction of an infinite sheet and an assumed density contrast between the Cenozoic and pre-Tertiary rocks of $-0.4 \mathrm{~g}$ per $\mathrm{cm}^{3}$, one can conclude that the thickness of the Cenozoic deposits in this area is greater than 11,000 feet; to obtain this result, removal of the regional gravity gradient was found to reduce the residual gravity relief to about 60 mgals. From the steepness of the gravity gradients surrounding the anomaly, it may be concluded that the Cenozoic and pre-Tertiary interface dips very steeply and is probably a fault contact. The gravity high near the center of the low anomaly may be the expression of a mass of dense rock within the Cenozoic section.

Slightly east of south from the southern boundary of the Long Valley gravity low, a sharp change in the direction of the gravity contours coincides in part with a fault as mapped by C. D. Rinehart and D. C. Ross (written commun., 1957). The area of low gravity trending approximately along the course of Owens River southeast of Lake Crowley must represent a relatively thick accumulation of the Bishop tuff of Gilbert (1938) and perhaps of other light materials of Cenozoic age. The small gravity low west of the southern end of the Benton Range is clearly related to the faulting in that area. In many other places, small gravity lows in the valleys that flank the ranges reveal moderately thick accumulations of valley-fill deposits.

The broad area of high gravity embracing the Benton
Range, Black Mountain, Blind Spring Hill, and some smaller features is an expression of the fact that preTertiary rocks are at or near the surface in this area. The elongated gravity low trending just east of south along the eastern front of the White Mountains has a residual gravity relief of about $30 \mathrm{mgals}$ and is bounded by steep gradients on both sides. It is presumably the expression of an accumulation of light Cenozoic rocks several thousand feet thick; the steepness of the gravity gradients suggests that this block of light material is probably bounded by faults on both sides. This gravity low continues with only minor interruptions to the southern limit of Owens Valley.

\section{NORTHERN OWENS VALLEY}

The northern Owens Valley area extends from lat $37^{\circ} 00^{\prime}$ to $37^{\circ} 30^{\prime}$ and from long $118^{\circ} 00^{\prime}$ to $118^{\circ} 45^{\prime}$. It includes the slopes of the Sierra Nevada, the White Mountains, Round Valley, and Deep Spring Valley, in addition to Owens Valley. The geology shown on the map (pl. 1, sheet 2) was taken from the compilation by Bateman and Merriam (1954), which includes data from Knopf (1918), and recent mapping by Bateman. The geology in the Deep Spring Valley area was taken from Miller (1928).

The gravity low in Owens Valley is a southward continuation of the same feature occurring west of the northern White Mountains noted above. The maximum residual gravity relief in this part of Owens Valley is about $30 \mathrm{mgals}$, indicating that more than 5,000 feet of Cenozoic rocks have accumulated, based on the assumption that the density contrast between the Cenozoic rocks and pre-Tertiary rocks is $-0.4 \mathrm{~g}$ per $\mathrm{cm}^{3}$. The gravity gradients are steep along the eastern side of the valley; therefore, the Cenozoic and preTertiary interface is probably a fault contact there. To the south, the gradients are also steep on the western side, but the relatively gentle gradients along most of the Sierra Nevada front suggest that the Cenozoic and pre-Tertiary contact may have been warped, as had been concluded on the basis of geologic mapping by $\mathbf{P}$. C. Bateman (written commun., 1956). The Owens Valley low branches westward into Round Valley in the southern part of the Volcanic Tableland and north of Tungsten Hills and has gentle gradients on both sides of the anomaly; this low suggests that the area may have been downwarped.

A dominant gravity high interrupts the Owens Valley gravity low northeast of Bishop. This gravity high must be the expression of a mass of dense rock within or surrounded by the Cenozoic section. Deep Spring Valley is clearly expressed by a closed gravity low that indicates a fairly thick section of light valley-fill deposits. 
The western front of the White Mountains is offset sharply to the west south of a line just north of the 37 th parallel. The gravity contours are also deflected sharply at the same place in a direction normal to their general trend; south of the offset the gravity low continues its southerly trend. The broad but gentle gravity low south and slightly west of Tungsten Hills (in the Buttermilk Country) probably represents an accumulation of alluvium about 1,000 feet thick; this gravity low is poorly defined by gravity observations.

CENTRAL OWENS VALLEY

The central Owens Valley area extends from lat $36^{\circ} 30^{\prime}$ to $37^{\circ} 00^{\prime}$ and from long $117^{\circ} 45^{\prime}$ to $118^{\circ} 30^{\prime}$. The area includes the slopes of the Sierra Nevada, Alabama Hills, the Inyo Mountains, and Owens Valley. Part of the western side of Saline Valley is also included on the map (pl. 1, sheet 3). The geology shown on the map was taken from the compilation by Bateman and Merriam (1954), which in this area is based on the mapping of Knopf (1918).

The Owens Valley gravity low is very narrow in the northern half of this area; the residual gravity relief and gravity gradients are small compared with those to the north and south. Inspection of the gravity contours in this area suggests that the Owens Valley structural basin is very narrow, and the thickness of the Cenozoic deposits is probably relatively small. The gravity low broadens to the south, however, where it is flanked by steep gravity gradients on both sides. The steep gravity gradient on the west lies along the eastern front of Alabama Hills and is several miles from the Sierra Nevada front. On the east, the steep gravity gradient marks the boundary between the Inyo Mountains and Owens Valley. These steep gravity gradients shown in the southern half of the central Owens Valley area probably indicate that the Cenozoic and pre-Tertiary rocks are in fault contact. The lack of pronounced local gravity relief between Alabama Hills and the Sierra Nevada suggests that the pre-Tertiary floor is shallow in this area; indeed, several outcrops of pre-Tertiary rocks project above the alluvium there.

The gravity field declines sharply in intensity from the Inyo Mountains into Saline Valley. D. R. Mabey (written commun., 1958) is making a study of Saline Valley. The gravity high of Alabama Hills continues in an area of alluvial cover to the north for a distance roughly equal to the exposed part of this feature, and the elongated gravity high is sharply terminated on the north. The Alabama Hills gravity high is also sharply terminated on the south. The gravity data in the southern part of central Owens Valley were previously presented by Kane and Pakiser (1961).
OWENS LAKE BASIN

The area of the Owens Lake basin is the extreme southern part of the region studied (pl. 1, sheet 3 ). The area includes the slopes of the Sierra Nevada, the Owens Lake basin (the southern part of Owens Valley), the southeastern end of the Inyo Mountains, the Coso Range, and Centennial Flat. The geology shown on the map was compiled from Bateman and Merriam (1954), who obtained geologic data from Knopf (1918), from Hopper (1947), and from maps published by the California Division of Mines (Jennings, 1958; Jennings and Strand, 1958).

The Owens Valley gravity low in this area flares southward into a broad gravity minimum, which is lowest near the center of Owens Lake. The residual gravity relief in this area is about $40 \mathrm{mgals}$. Computation of the thickness of an infinite sheet based on this gravity anomaly and on an assumed density contrast of $-0.5 \mathrm{~g}$ per $\mathrm{cm}^{3}$ between the basin sedimentary rocks and pre-Tertiary rocks yields a minimum depth of valley fill of about 6,000 feet. The larger density contrast was assumed because of the probability that the basin sedimentary rocks are finer grained, better sorted, and less dense in this area than elsewhere in Owens Valley (Kane and Pakiser, 1961). The intricate changes in direction of the gravity contours for this area suggest a complex fault pattern. The steep gravity gradients along the western front of the Inyo Mountains gradually die out to the south and are terminated southeast of lower Centennial Flat. The fault zone suggested by this zone of steep gravity gradients (pl. 1) has a total length from north to south of more than 100 miles with only a single interruption. On the extreme south, the Owens Valley low becomes narrow at the junction of Owens Valley and Rose Valley.

\section{GRAVITY EFFECTS OF DENSE PRE-TERTIARY ROCKS}

The measurements of the densities of samples of preTertiary rocks and a study of the variation of the gravity field in pre-Tertiary terrains indicate that the metamorphosed sedimentary and volcanic rocks of the roof pendants and septa of the Sierra Nevada are somewhat more dense than the rocks of the batholith. Therefore, large masses of these older, more dense rocks may bo expected to influence the gravity field. The gravity effects of these dense rocks may be determined by a direct inspection of the gravity contours for areas where these two pre-Tertiary rock types are in contact. Two such areas are Alabama Hills and the slopes of the Sierra Nevada southwest of Long Valley.

In Alabama Hills metavolcanic rocks of Triassic age are exposed on the east; Cretaceous (?) granitoid rocks crop out to the west. The gravity high over the meta- 
volcanic rocks is caused in paft by the density contrast between these rocks and the granitoid rocks farther west. The residual gravity relief caused by this density contrast (assumed to be about $0.2 \mathrm{~g} \mathrm{per} \mathrm{cm}^{3}$ ) is not more than 2 or 3 mgals, however, and this residual relief is not enough to have a serious effect on analysis of Cenozoic structures based on a single density contrast of -0.4 or $-0.5 \mathrm{~g} \mathrm{per} \mathrm{cm}^{3}$. In the slopes of the Sierra Nevada southwest of Long Valley, alternating bands of metamorphic and granitoid rocks trend into the steep southern gradient of Long Valley. Although the gravity contours in this area reveal small maximums over the metamorphic rocks, the effects are small and do not influence the much larger minimum anomaly of the Long Valley block caused by the density contrast between the Cenozoic and pre-Tertiary rocks. The effect is merely to superimpose small anomalies of a few milligals on an anomaly of several tens of milligals. It is thus probably safe to ignore density changes within the pre-Tertiary rocks. H. W. Oliver (written commun., 1959) is making a detailed study of the significance of these changes.

\section{REGIONAL GRAVITY AND ISOBTATIC COMPENBATION}

By subtracting 1,000 mgals from the contour values, the regional gravity over areas of pre-Tertiary rock outcrops with respect to the International Ellipsoid tends to be about -200 mgals. The regional gradient, decreasing to the west, is generally about 2 or 3 mgals per mile, although it is nearly zero in the Mono Basin area (Pakiser and others, 1960). The negative complete Bouguer gravity suggests that the crust is thicker than normal in this area and increases in thickness toward the west. Oliver (1956) is making a comprehensive study of the crustal structure and isostatic compensation of the Sierra Nevada; so, only a few generalized remarks are necessary in this paper.

The thickening of the crust in areas of large topographic loads -in the general area of the Sierra Nevada is also suggested by analysis of the dispersion of the phase velocity of Rayleigh waves from distant earthquakes (Ewing and Press, 1959; Press, 1956).

In the Long Valley area, the complete Bouguer gravity is about -230 mgals if the effect of the Cenozoic rocks is removed. This corresponds to a crustal thickening of more than $13 \mathrm{~km}$ if a density contrast of -0.43 $\mathrm{g}$ per $\mathrm{cm}^{3}$ is assumed between the rocks of the crust and the mantle rocks (Worzel and Shurbet, 1955). If the normal thickness of the continental crust at sea level is $35 \mathrm{~km}$, the crust is probably more than $48 \mathrm{~km}$ thick in the eastern Sierra of the Long Valley area, and it becomes thicker farther west. In the Owens Lake area, the complete Bouguer gravity with the geologic effect of the Owens Lake basin removed is about -200 mgals, which suggests a minimum crustal thickness of about $46 \mathrm{~km}$. The thickness of the crust also increases to the west in the Owens Lake area. Thus, the thickness of the crust on the Owens Valley region may range generally from about 45 to $50 \mathrm{~km}$, and this thickness corresponds to a general altitude of the region of about $5,000-8,000$ feet above sea level if regional isostatic equilibrium is maintained.

Of course, some of the variations in regional gravity may be the result of density variations within the rocks of the crust (Thompson and Sandberg, 1958), but the foregoing general conclusions should be valid; they are supported by the results from the analysis of Rayleigh waves.

\section{ANALYSIS OF GRAVITY PROFILES}

Eight gravity profiles ( $A-A^{\prime \prime \prime}$ to $B-H^{\prime}$, pl. 1 ; figs. 6-15) were analyzed in detail. In these analyses, with two exceptions, the density contrast between the Cenozoic and pre-Tertiary rocks was assumed to be $-0.4 \mathrm{~g}$ per $\mathrm{cm}^{3}$. In the analysis of profiles $D-D^{\prime}$ and $H-H^{\prime}$, a density contrast of $-0.5 \mathrm{~g}$ per $\mathrm{cm}^{3}$ was used, on the assumption that the fine-grained well-sorted sedimentary rocks of northern Owens Valley and the Owens Lake basin are less dense than the Cenozoic rocks elsewhere in the Owens Valley region (Kane and Pakiser, 1961). This refinement may be meaningless when the many uncertainties in the gravity interpretation are considered, but it seems to bring the depths determined from gravity and seismic data into close agreement, where they can be compared. The seismic data considerably strengthen the assumptions used in the gravity interpretation and the conclusions reached.

A single interface of density contrast was assumed in the analyses of gravity profiles. Variations in density within the Cenozoic section may occur and may lead to small errors in the dip and position of faults based on the gravity interpretation, as Kane and Pakiser (1961), following a suggestion of D. R. Mabey (written commun., 1956), showed. Specifically, failure to take into account the probably high density of the coarse and poorly sorted alluvial-fan materials near mountain fronts may result in a determination of the locations of faults valleyward from their true positions, a reduction of the estimates of the dips of faults from their probably steeper true dips, and a determination of the upper edges of the faulted pre-Tertiary rocks downward from their probably shallower true depths. These uncertainties must be recognized, but they do not significantly alter the conclusions that follow.

The true density contrast may range from -0.7 to $-0.3 \mathrm{~g}$ per $\mathrm{cm}^{3}$, and this uncertainty could result in a 

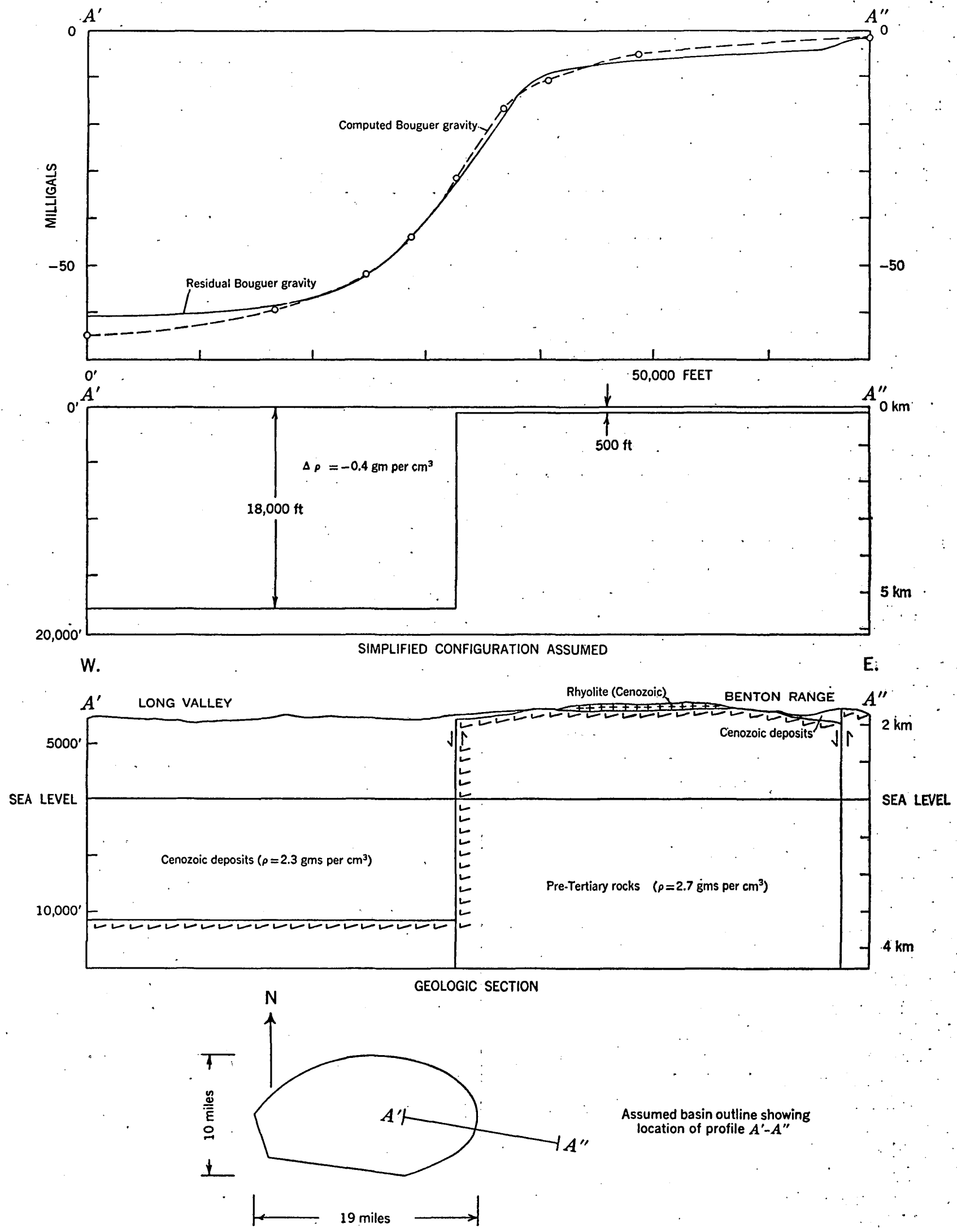

Figonw 6.-Analysis of gravity profle $A^{\prime}-A^{\prime \prime}$ across eastern Long Valley, showing assumed subsurface structure. 


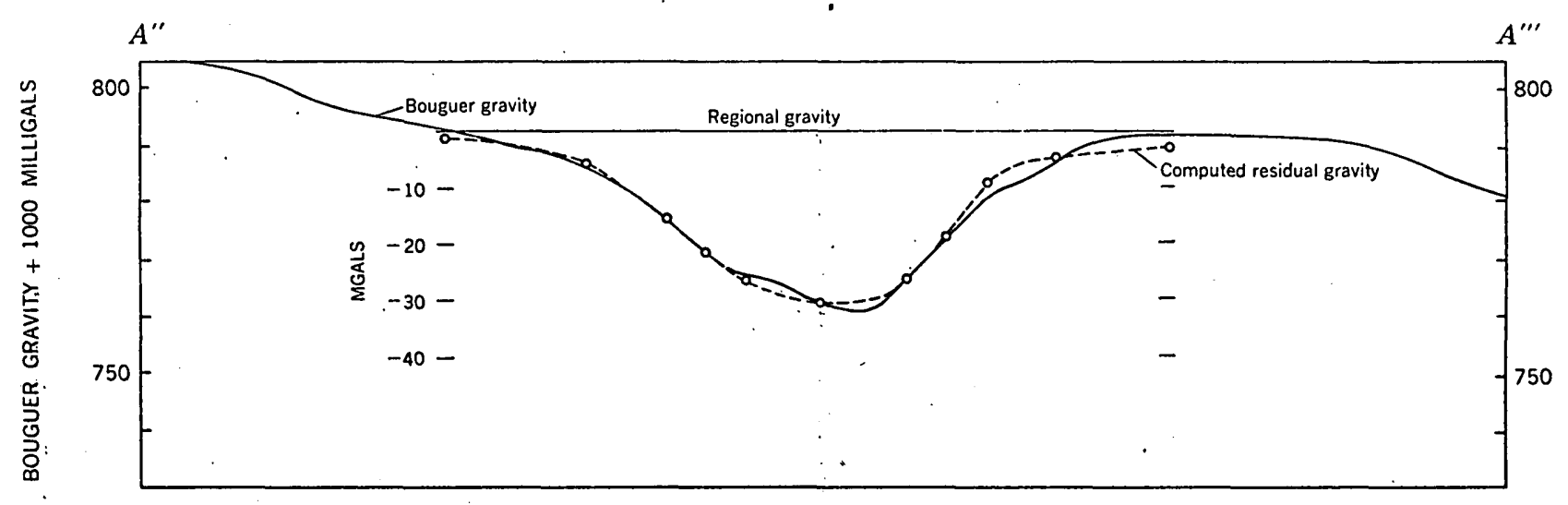

E.

W.

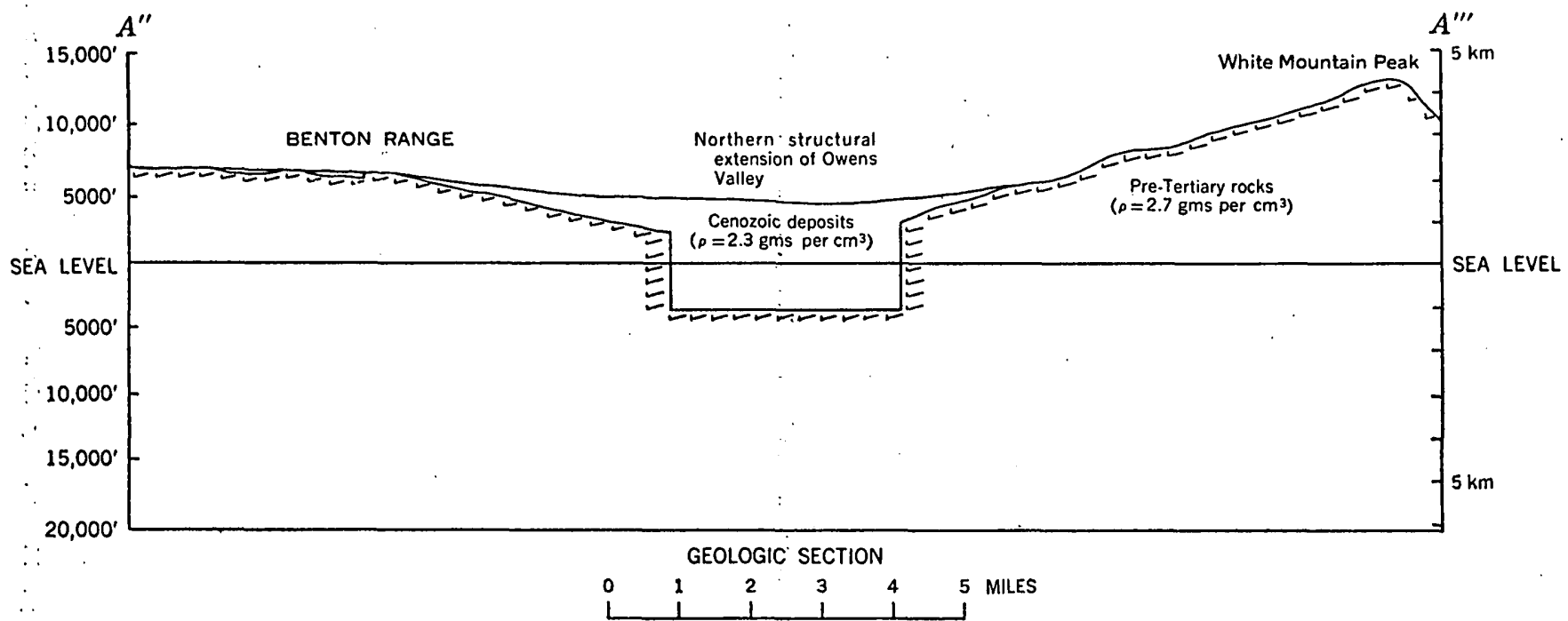

Froone 7.-Analysis of gravity profile $A^{\prime \prime}-A^{\prime \prime \prime}$ across northern extension of Owens Valley, showing assumed subsurface structure.

range of estimated depths to pre-Tertiary rocks of from about $2 / 3$ to $1 \frac{1}{2}$ times the depths found from the gravity data. The seismic data, however, considerably narrow this range of uncertainty, perhaps to \pm 25 percent.

The major faults were arbitrarily assumed to be vertical for convenience, but this assumption is not contradicted by the gravity evidence.

\section{PROFILE A-AO',}

Two sections of profile $A-A^{\prime \prime \prime}$ (pl. 1, sheet 1) were analyzed in detail (figs. 6 and 7 ), and the entire profile was assembled, together with the areal geology and some aeromagnetic data, to yield a regional geologic cross section along a line extending about 50 miles from the Sierra Nevada on the west to the White Mountains on the east (fig. 8).

The subsurface geologic configuration along section $A^{\prime}-A^{\prime \prime}$ was determined by measuring the sum of the solid angles from a series of points on the surface of a sequence of slabs 4,000 feet thick having the outline . shown in figure 6. A solid-angle chart designed by Lachenbruch (1957) for geothermal studies was used to make the measurements of solid angle. The sum of the solid angles multiplied by a factor dependent on the thickness of the slabs and the assumed density contrast $\left(-0.4 \mathrm{~g}\right.$ per $\left.\mathrm{cm}^{3}\right)$ yielded the theoretical gravity anomaly of the assumed structure. This computed gravity anomaly was compared with the residual anomaly of the actual structure, and modifications were made in the assumed subsurface configuration until satisfactory agreement was obtained. The Long Valley block included within the outline was assumed to be bounded by vertical faults; all slabs have the same size. The total thickness of Cenozoic deposits was assumed to be 18,000 feet, or $5.5 \mathrm{~km}$. The method of interpretation has been previously described in detail (Pakiser and others, 1960).

The configuration assumed for section $A^{\prime}-A^{\prime \prime}$ yielded a gravity anomaly that agreed almost perfectly with the 

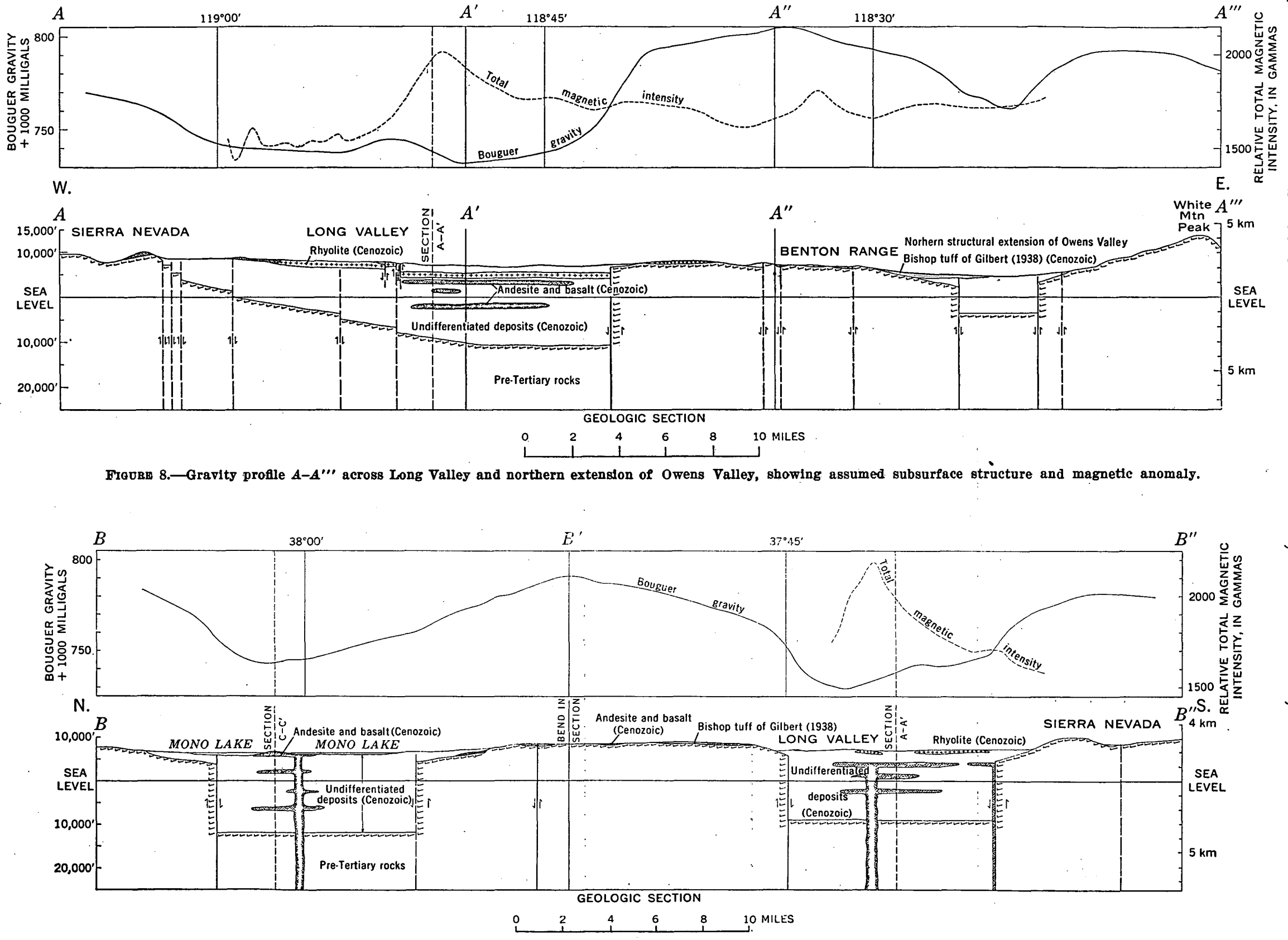

Frodnv 9. -Gravity profle $B-B^{\prime}$ across Mono Basin and Long Valley, showing assumed subsurface structure and magnetle anomaly. 


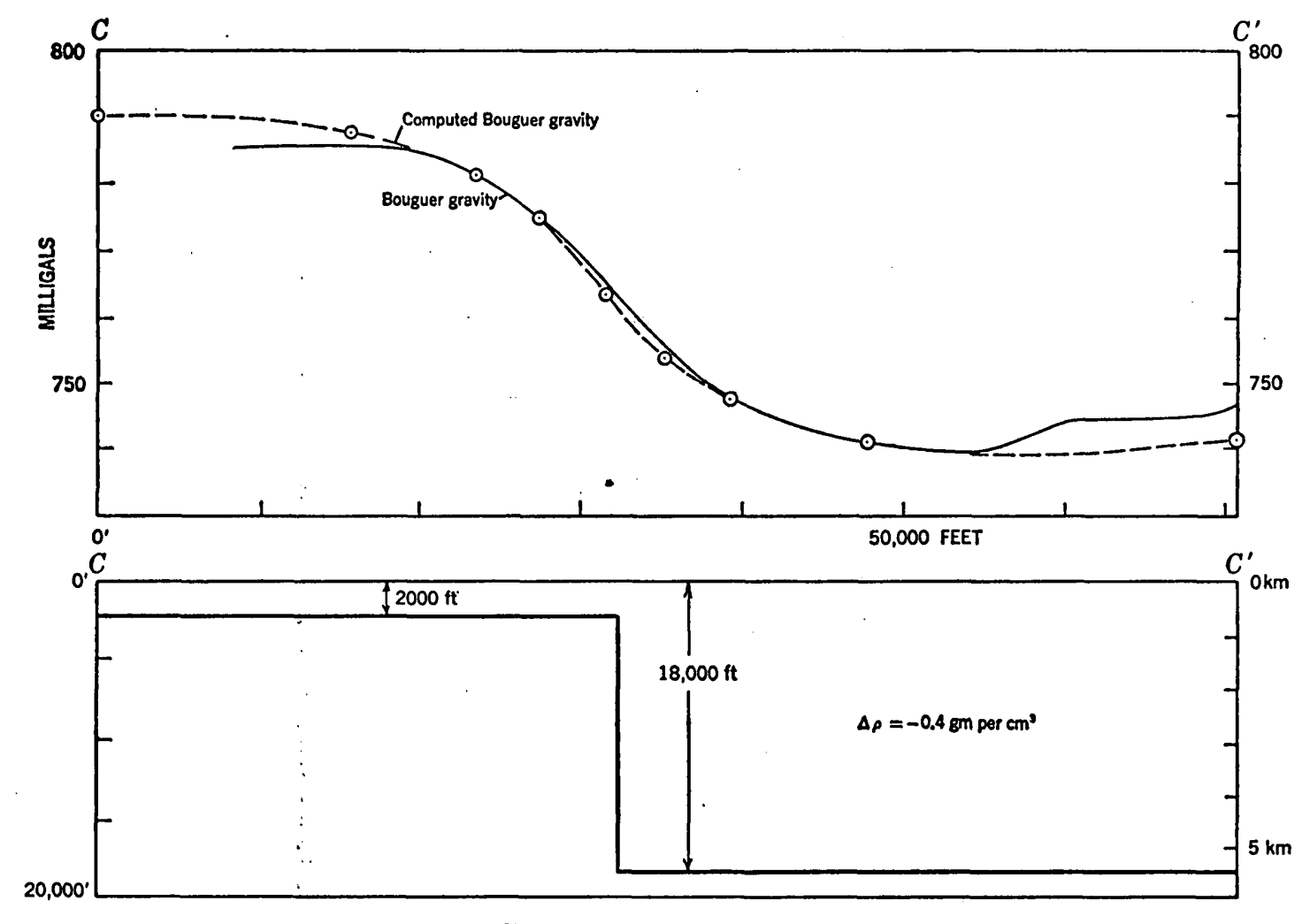

SW.

SIMPLIFIED CONFIGURATION. ASSUMED

NE.
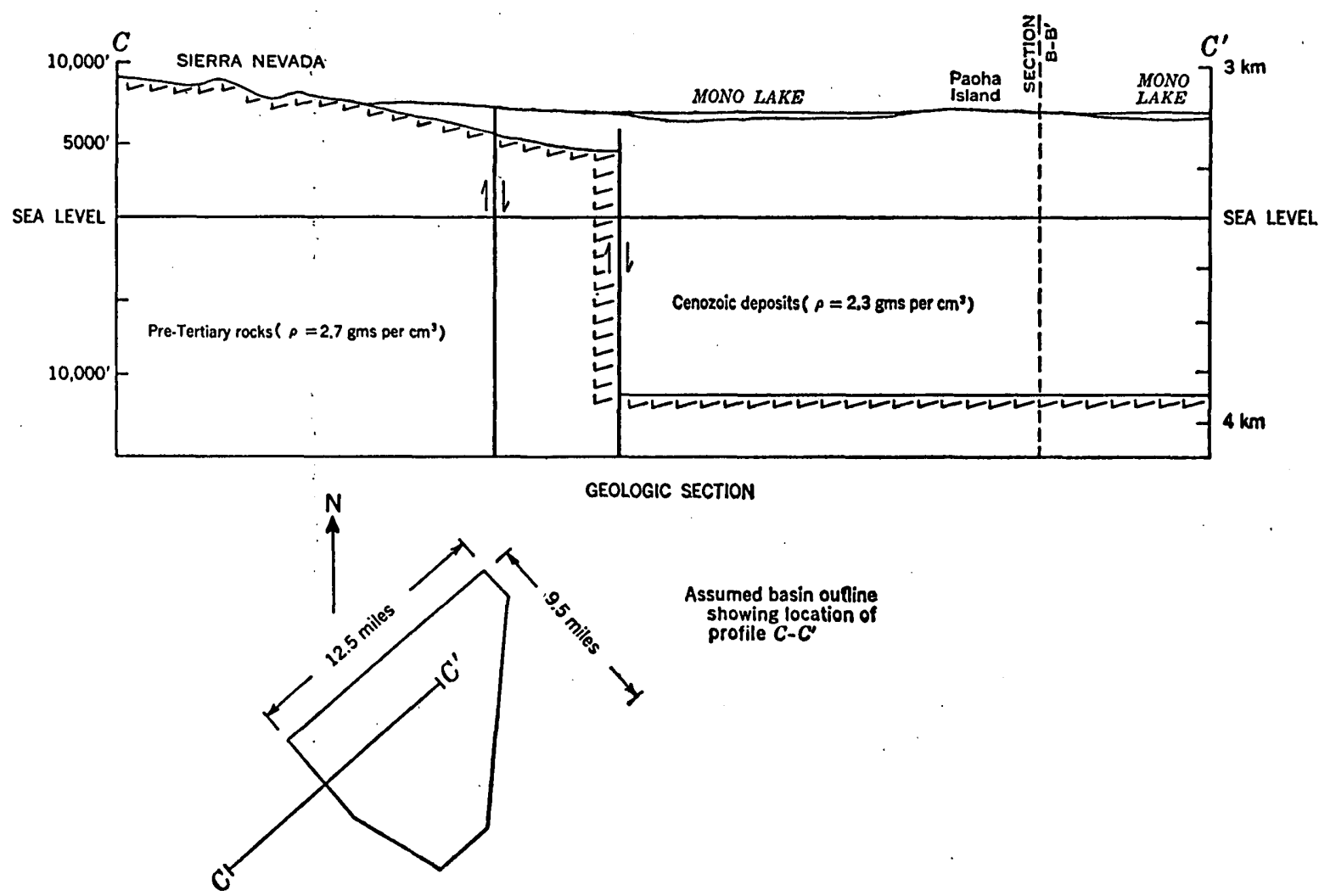

Assumed basin outline showing location of profile $C-C^{2}$

Froogw 10.-Analysts of gravity profile $\sigma-\sigma^{\prime}$ in Mono Basin, showing assumed subsurface structure. 


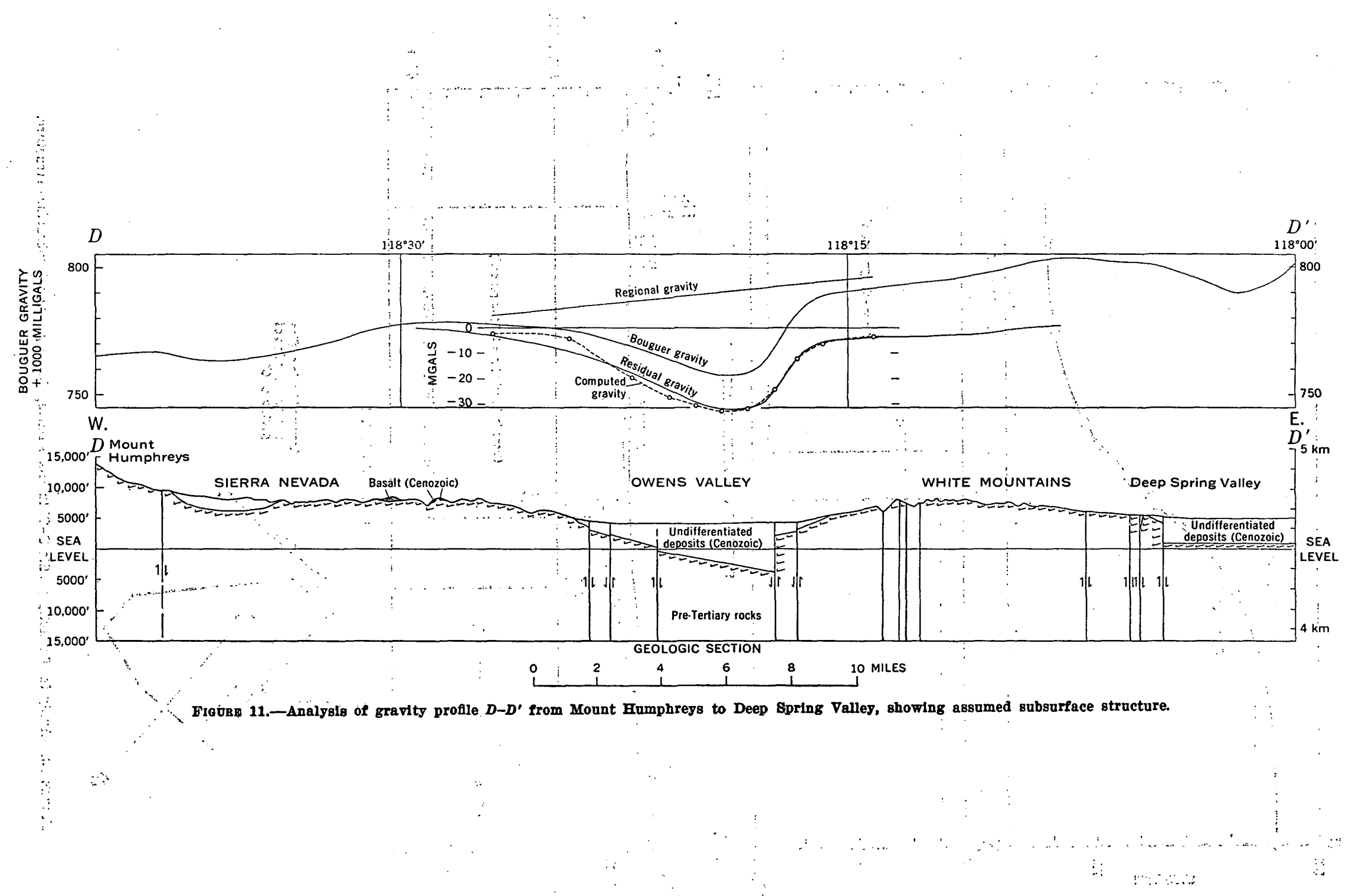




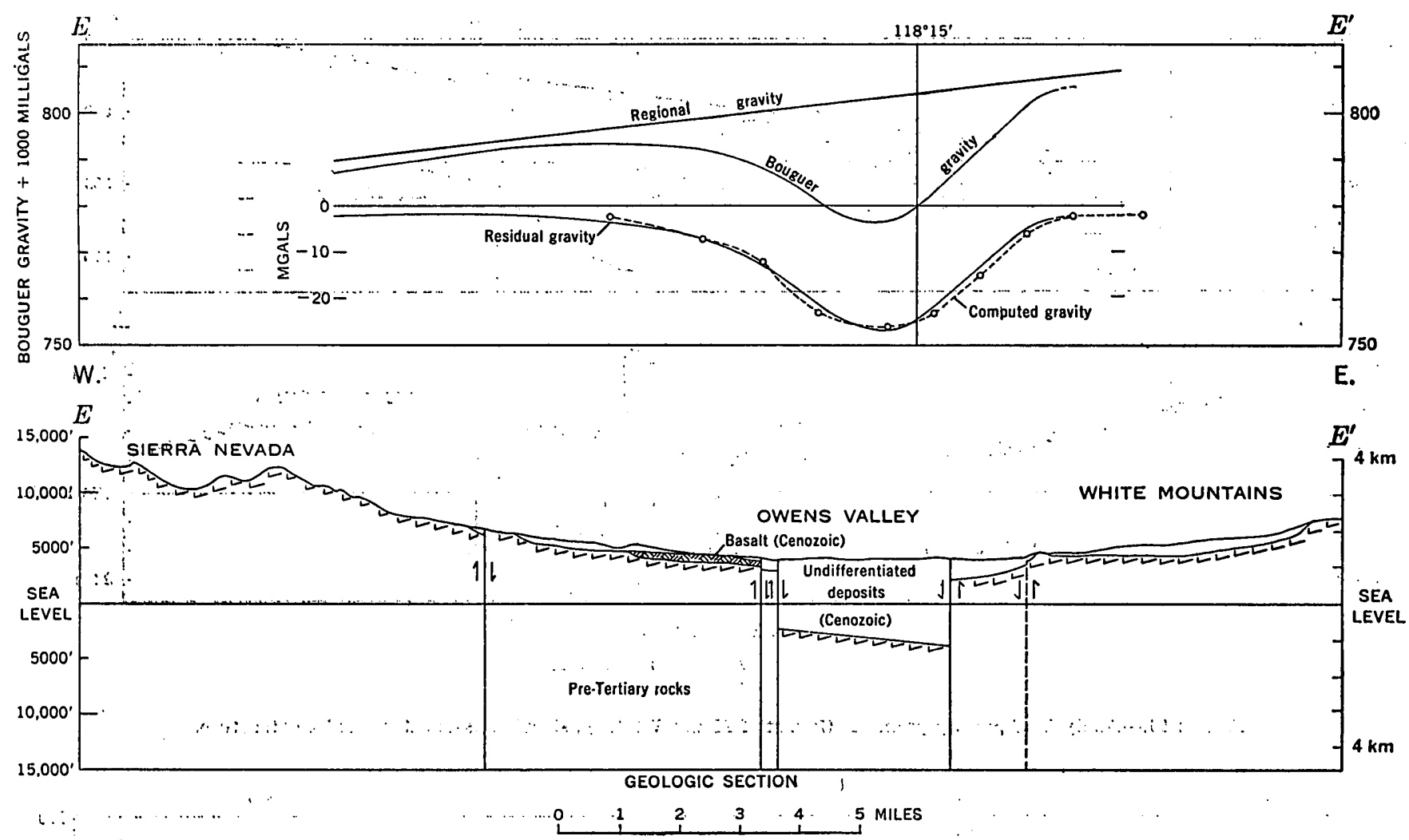

Fröorn 12.-Analysls of gravity profle $E-E^{\prime}$ near Big Pine, showing assumed subsurface structure.

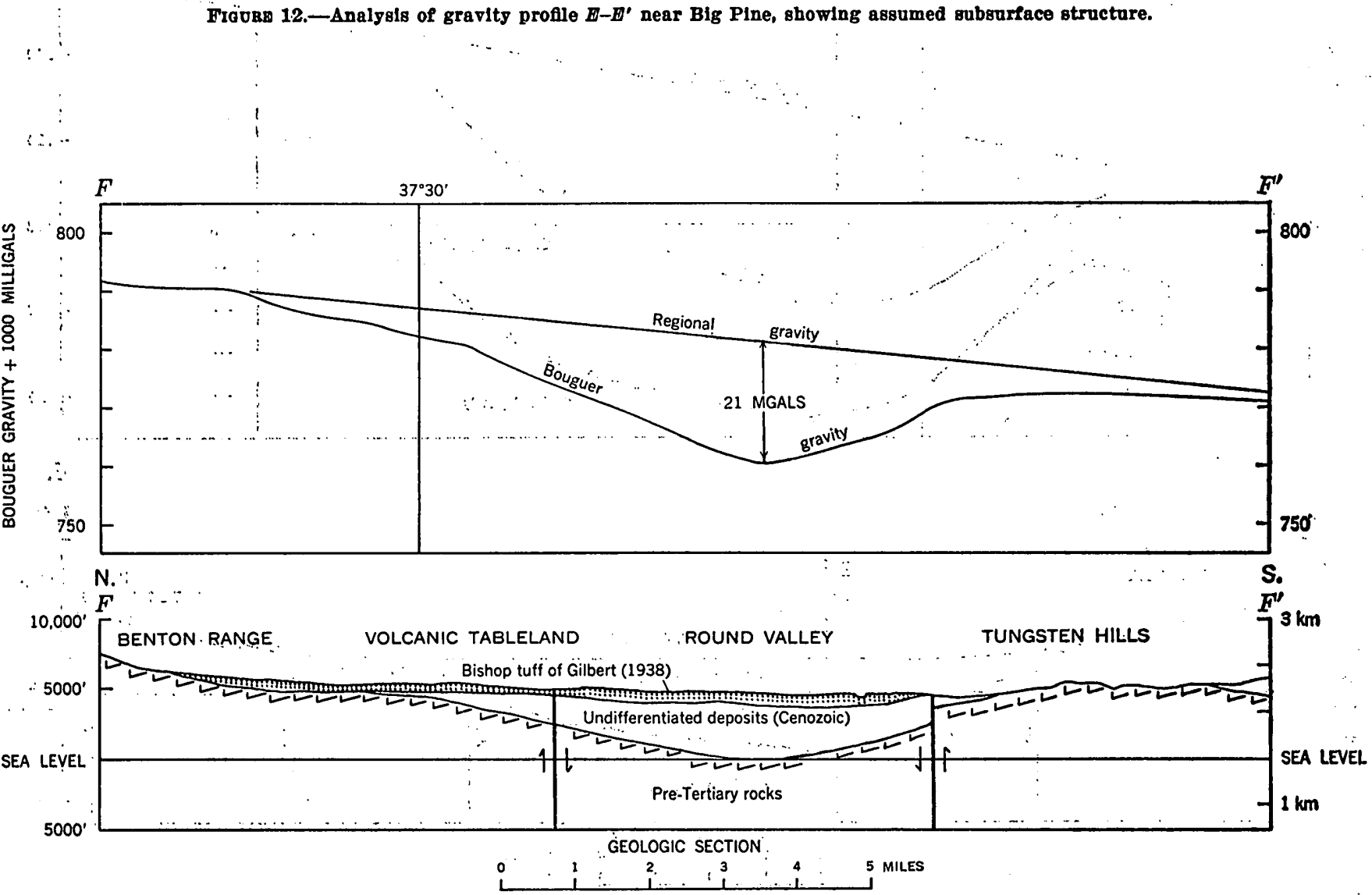

Figurs 13.-Aäalysis of gravity profle F-F" north of Tungsten Hills, showing assumed subsurface btructure 


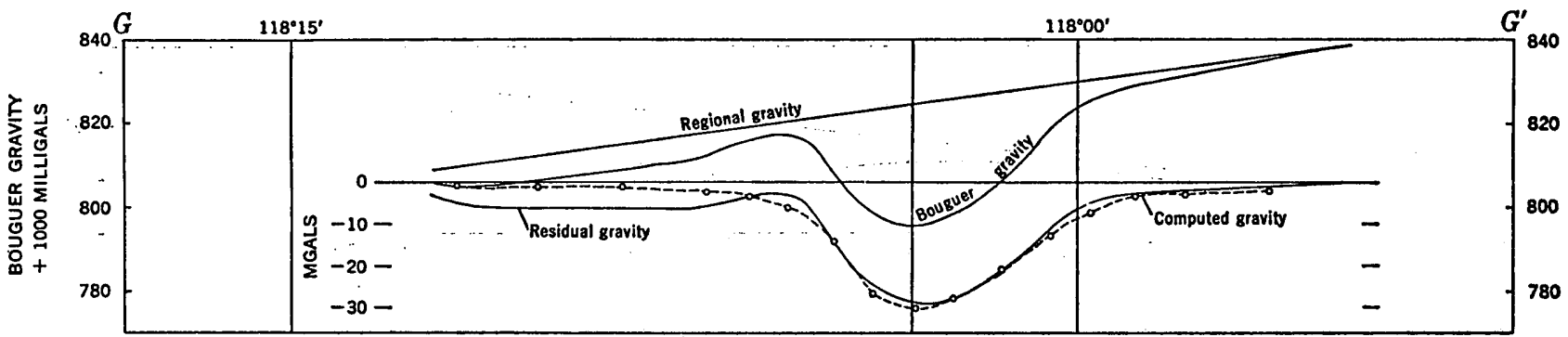

W.

E.

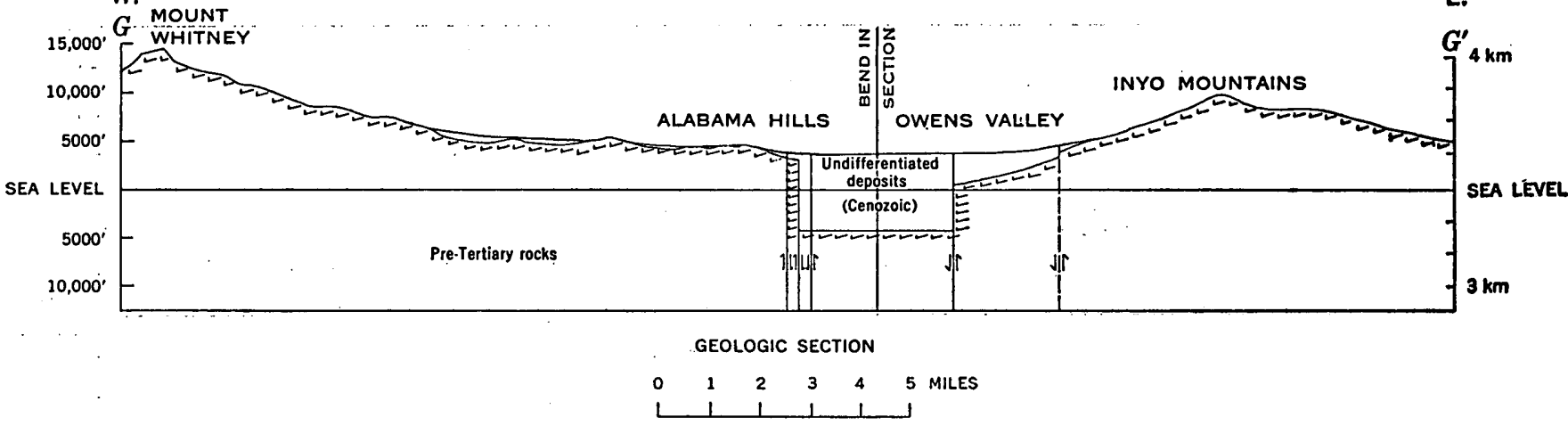

Frounw 14.-Analysis of gravity profle $Q-\sigma^{\prime}$ east of Mount Whitney, showing assumed subsurface structure.

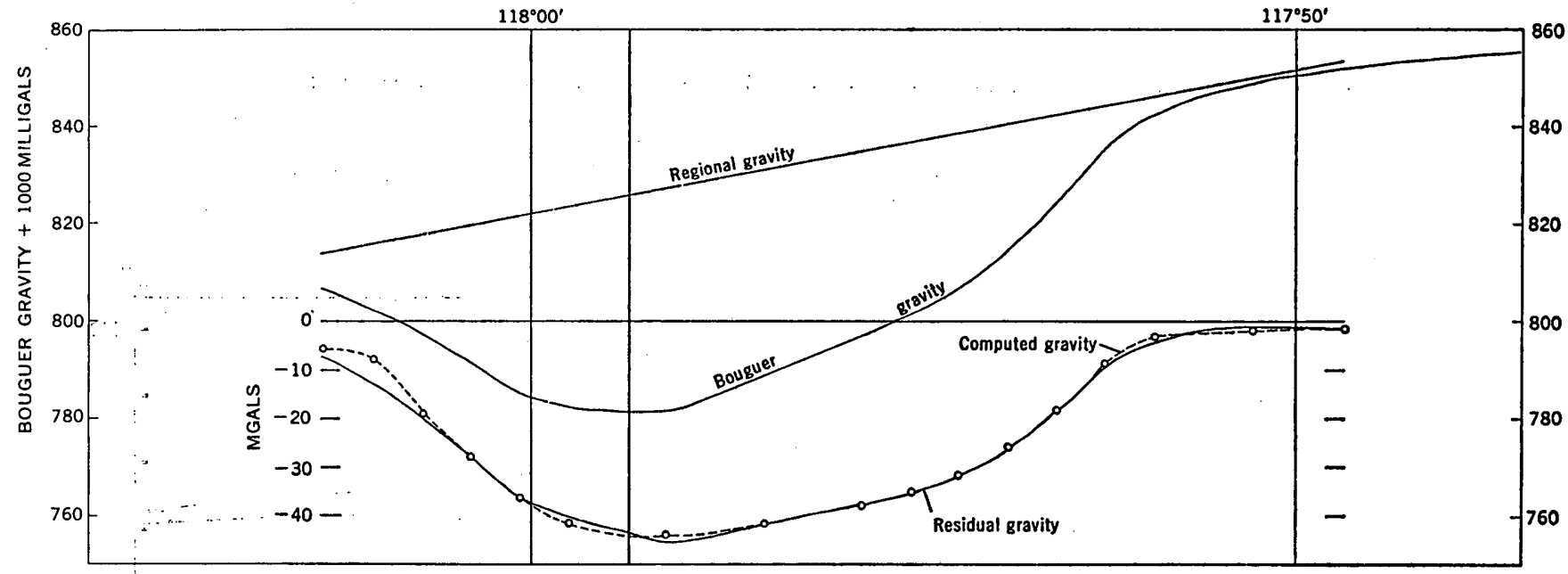

W.

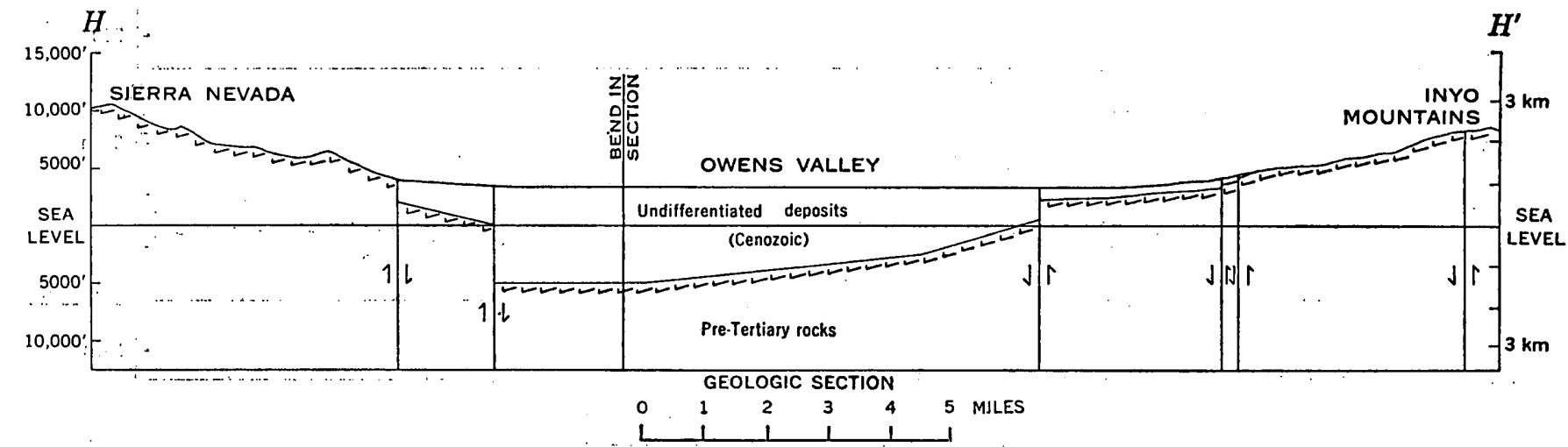

Figone: 15.-Analysis of gravity profle $B-B^{\prime}$ in Owens. Lake Basin; showing assumed subsurface structure. 
residual gravity anomaly taken from the gravity contour map (fig. 6). A gentle regional gradient had been removed before the anomaly was analyzed. In particular, the agreement in the zone of steepest gradients is excellent, and this agreement gives force to the conclusion that the system of faults that bounds the structure is actually vertical, or very nearly vertical. This section is particularly significant because determination of the form of the gravity anomaly is well controlled by gravity observations in this area. The surface relief is small; so, uncertainties concerning the altitude correction and terrain effects are small.

The subsurface geologic configuration along section $A^{\prime \prime}-A^{\prime \prime \prime}$ (fig. 7 ) was determined by measuring the angle subtended at a series of points on the surface by each of a sequence of slabs 1,000 feet thick and then by summing these angles. The slabs were assumed to extend without limit along axes normal to the plane of the cross section. The gravity anomaly at each point on the surface was found by multiplying the sum of the angles by a factor dependent on the thickness of the slabs and the density contrast $\left(-0.4 \mathrm{~g}\right.$ per $\left.\mathrm{cm}^{3}\right)$. This anomaly was then compared with the anomaly taken from the gravity contour map, and the determination of the subsurface configuration was modified as necessary, as previously described. A graticule designed by D. C. Skeels was used to make the measurements for this profile and for most of the others (see Dobrin, 1952, p. 98); a similar graticule, modified from Skeels by S. W. Stewart of the U.S. Geological Survey, was used for the remainder. See Hubbert (1948) for the theory of the method. The method of interpretation was previously described in detail by Kane and Pakiser (1961). Vertical bounding faults were assumed, and the thickness of Cenozoic deposits was assumed to be 8,000 feet. The agreement between the computed anomaly and the anomaly taken from the gravity contour map is fairly good.

No detailed analysis to infer the subsurface configuration along section $A-A^{\prime}$ (fig. 8 ) was made, but this configuration is clearly suggested by the smaller gravity relief and gentler gravity gradients along this line. Meticulous refinement of the interpretation along section $A-A^{\prime}$ is not considered to be necessary, and it might be misleading, in view of the paucity of gravity observations in the area near this line and of the relatively great effects of terrain in the slopes of the Sierra. The small gravity high near the center of Long Valley is not well defined by gravity observations; it is probably the expression of dense volcanic rocks within the Cenozoic section.

The sections analyzed in detail were then combined with the areal geology and the total-intensity aeromagnetic profile to obtain the regional geologic cross sec- tion $A-A^{\prime \prime \prime}$ (fig. 8). This cross section shows that the depth to the pre-Tertiary floor of Long Valley is more than twice as great as that of the northern Owens Valley basin. The aeromagnetic data were used to infer basalt flows within the Cenozoic section of Long Valley. Seismic-refraction measurements were used to infer a buried rhyolite flow east of the outcrop of rhyolite near the center of Long Valley. The volcanic rocks shown within the Cenozoic section on profile $A-A^{\prime \prime \prime}$, therefore, are based on good geophysical evidence, but the distribution shown is rather highly generalized.

\section{PROFILE $B-B$,}

A regional geologic cross section made on a line more than 50 miles long and extending southeastward from north of Mono Basin into the Sierra Nevada slopes south of Long Valley was compiled from areal geology and from gravity, seismic, and magnetic evidence (pl. 1, sheet 1 ; fig. 9). The structure, the velocity layering within the Cenozoic section, and the distribution of volcanic rocks in Mono Basin were deduced from gravity, seismic-refraction, and magnetic measurements (Pakiser and others, 1960). The bounding faults and the thickness of Cenozoic rocks of the Long Valley block were deduced from the gravity profile. A detailed analysis by graticule and solid angle measurements was made of the Long Valley gravity minimum, but it is not reproduced here. A good fit of computed gravity with the gravity taken from the map (pl. 1, sheet 1) was obtained, except at the local gravity high near the center of Long Valley. This high is assumed to be the expression of a basalt neck and a sequence of basalt flows within the Cenozoic section. The presence of this volcanic complex is also revealed by the aeromagnetic profile. The offset between the gravity and magnetic maximums may not be entirely real; the gravity profile was taken from the gravity contours, which are not controlled by gravity observations on or near this part of the profile. The small magnetic high directly over the southern bounding fault of the Long Valley block was used as evidence for the narrow basalt feeder dike in the fault zone shown on the cross section. The existence of the volcanic rocks within the Cenozoic section of Long Valley is based on good geophysical evidence, but the distribution as shown on the cross section is highly generalized.

The depth from the surface to the pre-Tertiary floor of Mono Basin is almost identical to that of Long Valley; both of these blocks have subsided to nearly the same depth below sea level (about 10,000 $\pm 5,000$ feet, or $3 \pm 1.5 \mathrm{~km}$ ), contain volcanic rocks within the Cenozoic section, and are bounded seemingly by vertical or nearvertical faults. 
PROFILE C-C'

Profile $C-C^{\prime}$ (fig. 10) extends along a line from the Sierra Nevada northeastward to and beyond the center of Mono Basin (pl. 1, sheet 1). The subsurface configuration of the Cenozoic and pre-Tertiary interface along this cross section is nearly identical with that of the northwestern part of profile $B-B^{\prime}$. This illustration has been reproduced from an earlier paper (Pakiser and others, 1960).

\section{PROFILE $D-D^{\prime}$}

A regional geologic cross section along a line more than 35 miles long, extending from the crest of the Sierra Nevada, across Owens Valley and the White Mountains to the eastern side of Deep Spring Valley was compiled from the areal geology and from gravity data (pl. 1, sheet 2 ; fig. 11). Only the Owens Valley gravity minimum was analyzed in detail. A density contrast of $-0.5 \mathrm{~g}$ per $\mathrm{cm}^{3}$ between the Cenozoic rocks and preTertiary rocks was assumed, and the analysis was made using the graticule designed by Skeels, as described on page 37. The main fault that forms the boundary between Owens Valley and the White Mountains was assumed to be vertical. This assumption is not contradicted by comparison of the computed gravity profile with the residual gravity profile as obtained from the gravity contour map. The agreement between these profiles is good. The maximum depth to pre-Tertiary rocks in Owens Valley just west of the White Mountains was assumed to be 8,000 feet. The pre-Tertiary floor slopes gently eastward from the Sierra Nevada to meet this fault. The thicknesses and approximate configurations of the pre-Tertiary floor in the valley just east of Mount Humphreys and in Deep Spring Valley were estimated from the amplitudes and forms of the gravity minimums in these two places; detailed analyses using a graticule were not made, mainly because the paucity of gravity observations near these segments of the profile would not justify such a procedure.

\section{PROFILE E-E}

Profile $E-E^{\prime}$ (pl. 1, sheet 2) extends for more than 20 miles along a line from the crest of the Sierra Nevada, eastward across Owens Valley, and into the White Mountains. A regional geologic cross section along this line has been constructed from the areal geology and from gravity data (fig. 12). The structure of the Owens Valley block was determined by comparing the residual gravity minimum as taken from the gravity contour map with the computed anomaly corresponding to the configuration assumed. The block was assumed to extend without limit along its strike. The faults bounding both the east and west sides of the Owens
Valley block were assumed to be vertical, and the thickness of the Cenozoic section was assumed to be 8,000 feet. A density contrast of $-0.4 \mathrm{~g}$ per $\mathrm{cm}^{3}$ was assumed between the Cenozoic and pre-Tertiary rocks. A good agreement between the computed anomaly and the residual anomaly taken from the gravity contour map was obtained.

\section{PROFILE $F-F$ '}

Profile $F-F^{\prime \prime}$ (pl. 1, sheet 2) was made for a line that extends for more than 15 miles southward from the southern tip of the Benton Range, across the Volcanic Tableland and Round Valley, and to the southern limit of Tungsten Hills. A geologic cross section (fig. 13) was constructed from the areal geology and from the gravity anomaly. No detailed analysis was made. The depth to and configuration of the pre-Tertiary floor was inferred from the amplitude of the residual gravity anomaly (21 mgals) and from the relatively gentle gravity gradients along the profile. The configuration of the pre-Tertiary floor is that of a gentle synclinal downwarp having subordinate faults.

\section{PROFILE G-G}

Profile $G-G^{\prime}$ extends eastward for more than 25 miles along a line from the summit of Mount Whitney, across Alabama Hills and Owens Valley, and beyond the summit of the Inyo Mountains (pl. 1, sheet 3). The regional geologic cross section (fig. 14) was constructed from the areal geology and from the subsurface configuration of the Cenozoic and pre-Tertiary interface as inferred from the residual gravity minimum. The gravity computed for the assumed configuration and the residual gravity as taken from the gravity map were compared, as described on page 37 , until a satisfactory agreement was obtained. The depth to the pre-Tertiary floor of Owens Valley was assumed to be 8,000 feet, and the density contrast between the Cenozoic and pre-Tertiary rocks was estimated to be $-0.4 \mathrm{~g}$ per $\mathrm{cm}^{3}$. The faults that bound the Owens Valley block were assumed to be vertical.

The relatively poor agreement between the theoretical and actual residual gravity profiles west of Alabama Hills is caused probably by the dense mass of metavolcanic rock that crops out in the eastern part of Alabama Hills and in part by a relatively thin veneer of alluvialfan materials between Alabama Hills and the Sierra Nevada front. The gravity stations that control this gravity profile between Alabama Hills and the Sierra Nevada are in the valley of Lone Pine Creek (pl. 1, sheet 3 ).

This cross section has been modified slightly from one along the same line given in a previous paper by Kane and Pakiser (1961). 
PROFILE $H-H^{\prime}$

Profile $H-H^{\prime}$ extends for nearly 25 miles along a line from the Sierra Nevada eastward to the center of the Owens Lake basin and from there northeastward to the crest of the southern Inyo Mountains (pl. 1, sheet 3). The regional geologic cross section (fig. 15) was constructed from the areal geology and from the subsurface configuration of the Cenozoic and pre-Tertiary interface as determined by detailed analysis of the gravity anomaly. The density contrast between the Cenozoic rocks and pre-Tertiary rocks was estimated as $-0.5 \mathrm{~g}$ per $\mathrm{cm}^{3}$, and the maximum thickness of the Cenozoic rocks was assumed to be 8,000 feet. Vertical bounding faults were assumed. The agreement between residual and theoretical gravity profiles is excellent except on the extreme west, where the gravity field is influenced by local deposits of alluvium on which the gravity observations were made. This cross section has been modified slightly from one along the same line by Kane and Pakiser (1961).

\section{DISCUSSION OF GRAVITY PROFILES}

The faults bounding each of the downfaulted blocks of Cenozoic rocks were assumed to be vertical. As has been pointed out, the effect of a wedge of denser alluvialfan materials within the Cenozoic section near the mountain fronts would minimize the estimate of the dip. On the other hand, because of the inherent ambiguity of gravity interpretations (Skeels, 1947), modification of data on the density contrast and the subsurface configuration could give satisfactory agreement between theoretical and actual gravity anomalies on most profiles having bounding-fault dips as small as $60^{\circ}$ and on a few profiles having even smaller bounding-fault dips. In any event, the dips of the bounding faults in zones of steep gravity gradient are steep, and the assumption of vertical dip has never been contradicted on the basis of the gravity data. Indeed, for the faults of Long Valley and Mono Basin, almost the only reasonable conclusion is that the faults are nearly vertical.

Although the density contrasts between the Cenozoic deposits and pre-Tertiary rocks were assumed on the basis of few valid measurements (measurements that will represent the entire Cenozoic section are virtually impossible to make), seismic data considerably narrow the uncertainty concerning the density contrasts. The density contrast of large volumes of Cenozoic deposits may be confidentially stated to range from -0.3 to -0.6 $\mathrm{g}$ per $\mathrm{cm}^{8}$. Locally, dense alluvial-fan materials near the mountain fronts may contrast in density with preTertiary rocks by as little as $-0.2 \mathrm{~g}$ per $\mathrm{cm}^{3}$. The smaller limit $(-0.3)$ would apply where a density contrast of $-0.4 \mathrm{~g}$ per $\mathrm{cm}^{3}$ was assumed; the larger $(-0.6)$, where $-0.5 \mathrm{~g}$ per $\mathrm{cm}^{3}$ was assumed. This range in density contrast corresponds approximately to an uncertainty of thickness of Cenozoic deposits of about \pm 25 percent. The greatest depth to pre-Tertiary rocks found in Long Valley and Mono Basin was 18,000 feet; this depth may be in error by $\pm 5,000$ feet. The greatest depth to pre-Tertiary rocks found in Owens Valley was 8,000 feet. This depth may be in error by $\pm 2,000$ feet.

\section{AEROMAGNETIC SURVEY}

An aeromagnetic survey of Long Valley, the Volcanic Tableland, and adjoining areas was made in 1956 (pl. 2). Flight lines spaced $1 / 2-1$ mile apart were flown east and west at a constant barometric altitude of 9,000 feet (about 2,000 feet above the ground). The magnetic contours were compiled with respect to an arbitrary magnetic datum; no correction was made for the regional variation of the magnetic field with latitude and longitude. At the same time, several long profiles were flown north and south across Mono Basin and Long Valley at a constant barometric altitude of 14,000 feet; an interpretation of these profiles in the Mono Basin area was previously reported by Pakiser, Press, and Kane (1960). Later, in 1958, a detailed aeromagnetic survey was made over the gravity high northeast of Bishop (fig. 16) ; lines were flown east and west, as shown on figure 16, at a flight altitude of 500 feet above the ground.

\section{MAGNETIC PROPERTIES}

The magnetic properties of several samples of preTertiary plutonic rocks and Cenozoic volcanic rocks from the Long Valley area have been measured by William Huff of the U.S. Geological Survey. Of these samples, only plutonic rocks of dioritic composition and basalts are significantly high in magnetic susceptibilty.

Plutonic rocks of dioritic composition have a measured magnetic susceptibility of about $0.003 \mathrm{cgs}$ unit. The more silicic plutonic rocks average about $0.0004 \mathrm{cgs}$ unit in susceptibility. The basalts range in susceptibility from 0.001 to $0.0037 \mathrm{cgs}$ unit, and they have an average magnetic susceptibility of about 0.002 cgs unit. The volcanic rocks ranging from intermediate composition to rhyolite (including the Bishop tuff of Gilbert (1938)) have an average magnetic susceptibility of about $0.0002 \mathrm{cgs}$ unit, and none differs significantly from this average. Some oriented samples of basalt collected from the surface have magnetic moment vectors that differ significantly from the present direction of the earth's magnetic field. Thus, the magnetic contours may be expected to reveal the general distribution of volcanic rocks of basaltic composition and of plutonic rocks having a dioritic or more mafic composition. 


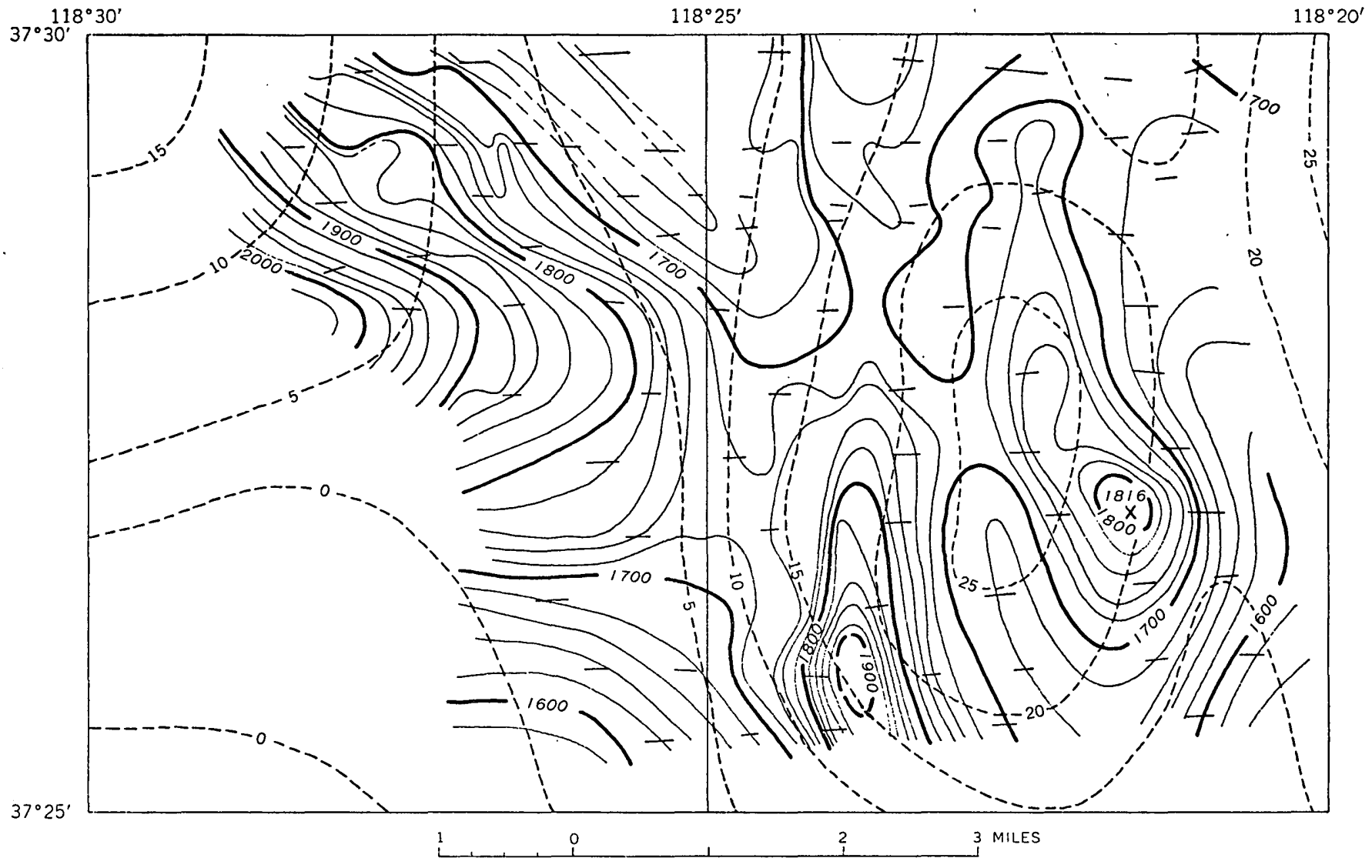

EXPLANATION
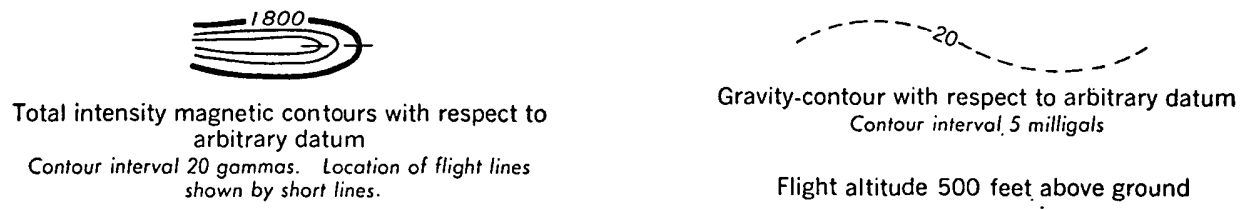

Flight altitude 500 feet above ground

FIGURE 16. - Comparison of magnetic and gravity contours for an area northeast of Bishop.

\section{MAGNETIC CONTOUR MAP}

The most striking feature on the magnetic contour map of the Long Valley-Volcanic Tableland area is the large area near the center of Long Valley where the magnetic field is anomalously high. This magnetic high consists of a broad feature on which are superimposed two anomalies, which are small in area but have a magnetic relief significantly greater than that in surrounding areas. The most dominant of these, which is in the northwestern part of the broader feature, is the most intense local magnetic anomaly in the area. This broad magnetic complex presumably is the expression of a magnetically heterogeneous mass of volcanic rock within the Cenozoic section of the Long Valley block. The steepness of the gradients indicates that the top of the mass must lie relatively near the surface, and the pre-Tertiary floor is known from gravity measurements to be several thousand feet deep in this area.
Southwest of the broad feature and just north and east of the Sierra Nevada front (in the southwestern part of the map, pl. 2) is an area of extremely erratic variations in the magnetic field. Basalt and some andesite crops out in this area, and the magnetic field is presumed to be the expression mainly of the basalt or the mafic andesite. To the north, at long $118^{\circ} 40^{\prime}$, is a sharp magnetic high having a small area; this high is assumed to be the expression of a volcanic neck of high magnetic susceptibility, presumably basalt. This magnetic high lies directly on the edge of a basalt flow and may represent the source of the flow.

The broad magnetic high trending north along and south of the east edge of the southern part of the Benton Range is presumably the expression of the Casa Diablo Mountain pluton, and the rock of this pluton must be more mafic than the granites exposed in the area. The main mass of the pluton is probably diorite. 
Samples of diorite from this general area were high in magnetic susceptibility. The magnetic low north of this broad high is in an area of outcropping granite and metasedimentary rocks that must be relatively low in magnetic susceptibility. The magnetic field is low over the northern extension of Owens Valley along the White Mountains front. The west gradient of this low probably marks the eastern boundary of the Casa Diablo Mountain pluton; the low may represent, in part, the Owens Valley structural basin. Gravity measurements in the area of the magnetic low show that the Cenozoic section is several thousand feet thick.

In the extreme southeastern part of the map (pl. 2), a broad magnetic high coincides with a pronounced gravity high (pl. 1, sheet 2). This magnetic high is revealed to be a composite of two sharp high anomalies on the magnetic contour map compiled from low-level flight lines (fig. 16). Interpretation of the gravity high suggests that it is caused by a mass of dense rock that projects upward from the pre-Tertiary floor to within about 1,000 feet of the surface; the probable horizontal outline of the mass is indicated approximately by the outline of the 20 -mgal contour of relative gravity (fig. 16). The magnetic contours suggest a mass having approximately the same outline; the rock is more magnetic on the east and west boundaries and is very near the surface. The gravity data show that the Cenozoic section is several thousand feet thick all around this anomaly.

\section{ANALYSIS OF SELECTED MAGNETIC ANOMALIES}

Two magnetic anomalies were selected for detailed analysis: the complex magnetic high near the center of Long Valley and the composite magnetic high that coincides in horizontal position with the gravity high northeast of Bishop (pl. 1, sheet 2 ; pl. 2 ; fig 16).

Estimates of depth to the upper surface of the mass expressed by the complex magnetic high near the center of Long Valley have been made by Isidore Zietz (written commun., 1958). The outline of the broader part of this mass is roughly indicated by the 1,750-gamma contour, and the depth to the upper edge of the mass along this broader part ranges from about 4,000 feet below the flight altitude on the northwest to about 6,500 feet below the flight altitude on the southeast. The depth estimates were made by measuring the horizontal extent of the steepest gradients along this outline. Steenland (in Vacquier and others, 1951, p. 11-15) showed that for rectangular prismatic models having cross-sectional dimensions that are large compared to the depth of burial the horizontal extents of steepest gradients are approximately equal to the depth. The difference in depth from the northwest to southeast may indicate that the upper surface of the mass slopes downward to the southeast; all depth estimates are consistent with this interpretation. Or, if an uncertainty of \pm 25 percent is considered probable in the estimates of depth, the depth to the upper and possibly horizontal surface may be about 5,000 feet below the flight altitude. The average altitude of the ground in this area is about 7,000 feet, and the depth to the upper surface of the mass below the ground is therefore about 3,000 feet (the aircraft at 9,000 feet); this surface may slope gently downward to the southeast.

Zietz found the depth to the source of the pronounced magnetic high in the northwestern part of the broader feature to be about 4,500 feet below the aircraft and the depth to the source of the magnetic high in the southeast to be about 4,000 feet below the aircraft. These masses of more highly magnetic rock are, therefore, at about the same depth as the larger mass. The mass to the northwest may be about 1 mile wide and 2 miles long, long axis extending northwestward; the mass to the southeast may be about 1 mile square horizontally.

One possible interpretation of this complex feature is that the larger mass, shown in outline by the 1,750gamma contour, consists of rock of intermediate magnetic susceptibility into which have been intruded, or from which have been segregated, the two smaller bodies composed of more highly magnetic rock. A gravity high in the same area, which unfortunately was not fully defined, indicates that the corresponding mass of dense rock is not as large in area as the larger mass inferred from magnetic data.

An alternative interpretation, which is preferred by the writers and is more consistent with the gravity data, would regard the smaller more highly magnetic masses as volcanic necks that were sources of a sequence of flows that are expressed by the broader feature. The sequence of flows would have been deposited concurrently with the Cenozoic clastic deposits but represent only a fraction of the total thickness $(18,000 \pm 5,000$ feet). Thus, they would have a magnetic relief that is small compared with the necks and the nearby thick flows, which continue downward to great depths, and their influence on the gravity field would be small. The highly generalized distribution of such a sequence of flows is shown on the regional geologic cross sections (figs. 8 and 9 ).

The larger of the masses of highly magnetic rock (the mass in the northwestern part of the broader feature) may consist actually of two or more necks whose magnetic anomalies merge and which were intruded along a northwestward-trending zone of weakness that extends into the mass to the southeast. The upper surface of the flows may slope to the southeast, and the lava from which they were solidified may have flowed in this direc- 
tion. This slope is consistent with the generally downward slope to the east of the pre-Tertiary floor as inferred from the gravity data (fig. 8).

A volcanic pile similar to that in Long Valley was inferred on the basis of magnetic and gravity data and of the outcrop of basalt on Paoha Island, near the center of Mono Basin (Pakiser and others, 1960).

A magnetic high flanked by gentle gradients coincides in horizontal position with the gravity high northeast of Bishop (pl. 1, sheet $2 ; \mathrm{pl} .2$ ). The surface altitude in this area is just over 4,000 feet, and the flight altitude for the lines from which the map (pl. 2) was compiled was about 9,000 feet. This relatively great height above the ground accounts for the small amplitude of the anomaly and for the gentle gradients. In order to obtain a clearer definition of the anomaly, a small area was reflown at an altitude of 500 feet above the ground. The magnetic contour map compiled from these lowaltitude lines shows that the anomaly consists actually of two separate magnetic highs with generally northerly trends and that the axes of these highs correspond closely with the east and west gradients of the gravity high (fig. 16). The gravity and magnetic highs are therefore both caused by the same dense and magnetic mass or group of masses.

Estimates of the depth to the top of the bodies that cause each of the two magnetic highs were made by the method described on page 41 . The depth to the top of the westernmost of the two bodies was estimated to be about 1,200 feet below the flight altitude, or about 700 feet below the surface of the ground. The depth to the top of the body to the east was found to be about 2,000 feet below the flight altitude, or 1,500 feet below the surface. Although approximate, these estimates indicate that the depth to the top of these bodies is about 1,000 feet below the surface of the ground. This depth corresponds closely with the estimated depth to the top of the mass expressed by the gravity anomaly. If the density contrast of this mass with respect to the Cenozoic valley fill is $0.5 \mathrm{~g}$ per $\mathrm{cm}^{3}$, the mass would be about 1,000 or 2,000 feet below the surface.

The narrow magnetic highs may be interpreted as the expressions of dikelike intrusions or perhaps of rows of volcanic necks that may have been sources for buried flows in this area. The presence of a complex pile of such flows, having a large aggregate thickness, and the related dikes or necks could readily explain both the gravity and magnetic anomalies. Although a magnetic low is between the two magnetic highs, the general level of the magnetic field in this area is higher than that in all nearby areas except one--to the west. This anomaly, in which the magnetic field rises to more than 2,000 gammas, is assumed to be the expression of the southern limit of the Casa Diablo Mountain pluton described on page 40.

An alternative interpretation would explain the gravity high and the associated magnetic highs as the expression of a large igenous intrusion in the Cenozoic rocks, which are generally about 5,000 or more feet thick in this area. The separate magnetic highs could be explained by the presence of more highly mafic and therefore more highly magnetic differentiates of the intrusive mass in which the more mafic minerals crystallized out along the borders early during the cooling of the mass and more silicic and less highly magnetic rock crystallized later in the core. No such intrusions of Cenozoic age are known in this area, but they may be buried under Cenozoic deposits.

A second alternative would explain both the gravity and magnetic anomalies as the expression of an upthrown block or blocks of pre-Tertiary rocks. If the anomalies are caused by a single block, the walls would seemingly be composed of material more highly magnetic than the interior (possibly basalt intruded along the bounding faults). If the anomalies are caused by two blocks, the blocks would be in the form of narrow upthrown slivers. The block or blocks of pre-Tertiary rock may necessarily have remained more or less stationary while the pre-Tertiary floor of Owens Valley subsided in the surrounding areas, and thus the stationary blocks might have the appearance of being upthrown blocks. The mechanism of such a deformation is difficult to conceive, but such seemingly anomalous movements of small masses contrary to the movement of larger blocks could possibly happen in a system of strike-slip faults.

The real nature of the mass of dense and magnetic rock in this area remains unknown. Only the general outline of the mass, which is indicated approximately by the 20-mgal contour of relative gravity, the shallow depth of burial (about 1,000 feet below the surface), and its necessarily steeply sloping sides are known with confidence.

\section{SEISMIC SURVEY}

In the following discussion of the seismic measurements, no attempt is made to identify the individual velocity units by rock type in other than very broad terms, such as pre-Tertiary rocks, younger Cenozoic deposits, and older Cenozoic deposits. It is very difficult to obtain a unique interpretation of the seismic data in terms of rock types without additional information because of the wide range of velocities possible in the sedimentary and igenous materials and the considerable overlap in the speeds with which seismic waves travel in the materials.

The interface between the Cenozoic and pre-Tertiary 
rocks is expressed by a marked velocity discontinuity that can be traced with reasonable accuracy throughout the Owens Valley region. The velocity in the preTertiary granitoid and metamorphic rocks ranges from 15,000 to $17,750 \mathrm{fps}$ (feet per second) (Pakiser and others, 1960) ; therefore, layers having velocities within this range can be identified with reasonable certainty as pre-Tertiary rocks. However, layers of evaporites, basalts, and rhyolite flows may also have velocities within this range; identification of pre-Tertiary rocks having a given velocity to some extent depends therefore on geologic relations, such as stratigraphic position.

Identification of units within the Cenozoic section is much more difficult. In both Long Valley and Owens Valley, three velocity zones were observed. The relatively thin upper layer is composed predominantly of aerated sands and gravels having a velocity of less than 2,000 fps. The next layer, having a velocity range of $5,000-6,200 \mathrm{fps}$, may represent water-saturated unconsolidated to semiconsolidated clastic or pyroclastic deposits. Velocities of 6,900-11,200 fps are within the range found in older Cenozoic rocks that are more highly indurated than the younger deposits having lower velocities. The higher velocities in this range are often associated with flow rocks and evaporites. Similar velocities were found in Mono Basin (Pakiser and others, 1960; see also Kane and Pakiser, 1961).

\section{SEISMIC FIEID METHODS AND INTERPRETATTON} OF DATA

Measurements were taken along five seismic-refraction profiles in Owens Valley and one in Long Valley (for location, see pl. 1). Conventional refraction methods were used in which the seismometer spread was held fixed and the shots were recorded at a number of distances from the spread. The method is equivalent to recording a reversed geophone spread.

With the exception of one 1,100-foot spread, the profiles were shot using 5,400-foot spreads having 12 geophones each. With the exception of profile 6 , the shot points were located on nearly straight lines extending from each end of the recording spreads at distances that were determined by the depth to pre-Tertiary rocks. In general, the distances of the shot points from the end of each spread were increased from a few tens of feet to distances as great as 26,000 feet. Dynamite charges of 10-15 pounds were adequate throughout most of Owens and Long Valleys; however, for many of the more distant shots and in a few locations on alluvial fans, charges of 20-50 pounds were required. Shot holes were drilled to below the water table where possible, using a truck-mounted auger or a rotary drill. On alluvial fans, holes were usually dug with shovels or hand augers, and the charges were placed 5-10 feet beneath the surface. Three records were taken of elevated air shots.

Conventional seismic-refraction equipment was used in taking the measurements. Radio communication was established between shooter and observer; the exact moment of the explosion was transmitted by radio and recorded on a separate trace of the record. The first arrivals could be read to the nearest 0.001 second for the shots nearer to the spreads and to 0.005 second for the more distant shots.

In determining depths from the observed traveltime data, conventional intercept-time or delay-time computing methods were used (Heiland, 1940, p. 506-533; Dobrin, 1952, p. 237-240; Nettleton, 1940, p. 250-251). The velocity layering, however, was determined only beneath the geophone spread, and only if the velocity increases with depth. The velocity layering was not known to be continuous under an entire profile, but this assumption was made unless information was available to indicate that the velocities changed laterally along the profile. If the intercept times at all shot points did not plot in a straight line, indicating that the refracting interfaces were not plane, the intercept times were separated into delay times corresponding to the two ends of the least-time path for each shot (Barthelmes, 1946). Depths to velocity discontinuities were computed using the delay times at each shot point.

The delay-time method used is approximate in that it does not adequately take into account the changes in dip and velocity below the refracting interfaces along the profile. Because of the uncertainties inherent in the refraction method, however, this approximation does not introduce serious errors, and refinements yielding presumably more accurate results can be misleading.

\section{ANALYSIS OF SEISMIC PROFIHES}

PROFILE 1

Seismic profile 1 (fig. 17) was shot in an area where the gravity data suggest that the depth to pre-Tertiary bedrock should be relatively shallow. Two 5,400-foot spreads of 12 geophones each were placed end to end along a straight line. Seismograms were recorded on the easternmost spread from shot points 1 and 2 and on the westernmost spread from shot points 3-6, and from a shot point 11,000 feet west of this spread at approximately the same location as shot point 5 , profile 2. Traveltime curves for shot points $1,2,4,5$, and 6 are plotted on figure 19. The arrival times for shot point 3 are omitted because no shot instant was ro corded on the seismogram.

Depths beneath shot points 1, 2, and 4 were computed using intercept times based on the assumption that velocity interfaces for a dipping layer were plane. 

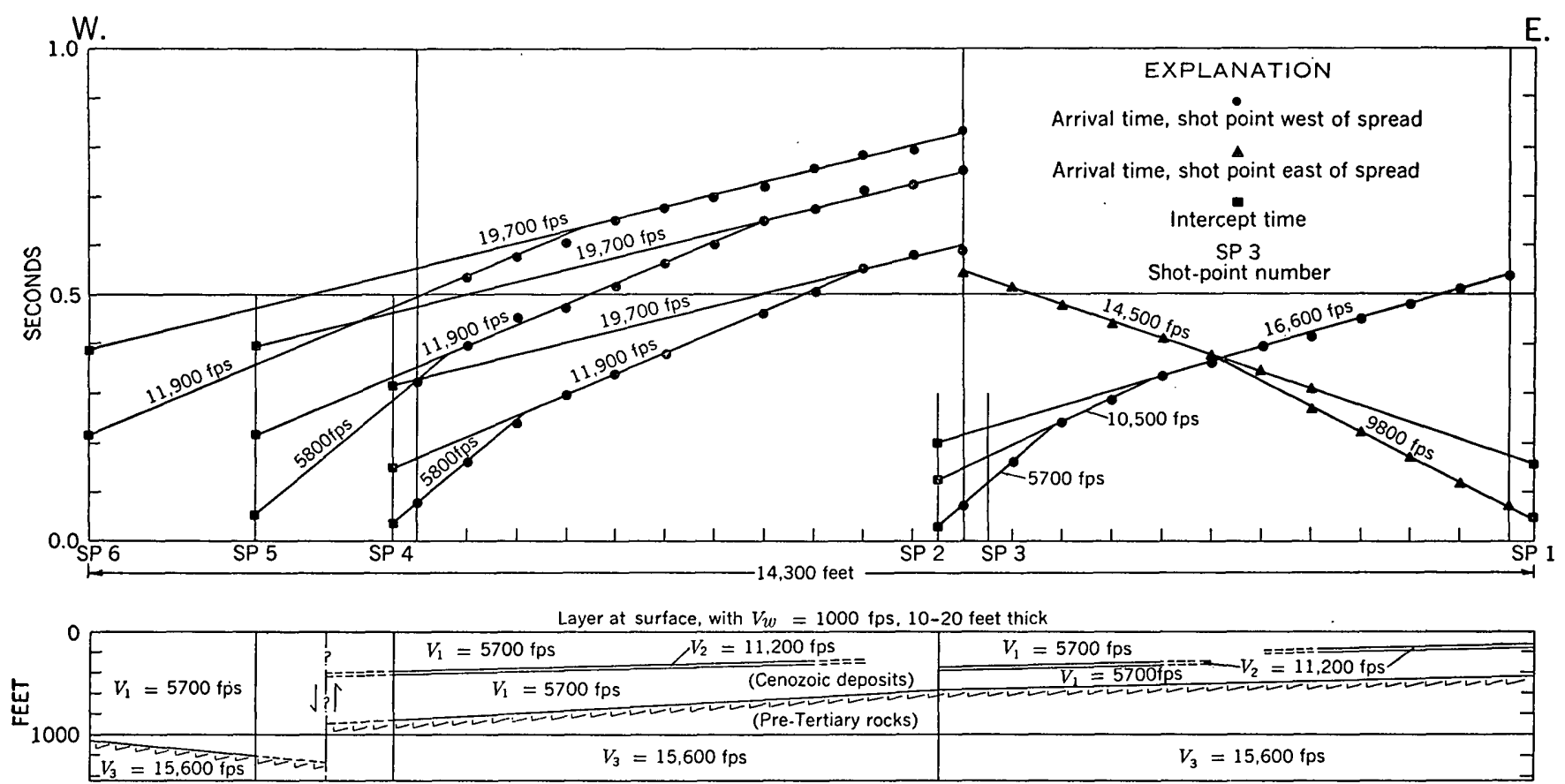

Figunn 17.-Analysis of seismic profle 1 southeast of Owens Lake.

A further assumption that a thin, discontinuous layer having a high velocity exists within the low-velocity Cenozoic rocks was made. This layer, having a velocity of 10,200 fps between shot points 1 and 2 and 11,200 fps between shot points 3 and 4 , was assumed to be thin because the arrivals that had traveled horizontally in this layer were sharply attenuated with distance from the shot points. The arrivals along this layer disappeared entirely at the sixth geophone from shot point 1 and at the third geophone from shot point 3 (not shown on fig. 17). The layer was arbitrarily assumed to be 50 feet thick in the interpretation of profile 1 , and the velocity directly beneath this layer was assumed to be $5,700 \mathrm{fps}$. The discontinuities in this layer were based on the results of intercept-time calculations at shot points 1, 2, and 4 and may not be significant; the layer may be continuous. Erratic magnetic anomalies, which are characteristic of volcanic rocks, were recorded on a trailer-borne magnetometer traverse in this area (G. D. Bath, oral commun., 1958).

The depths to the 15,600-fps layer between shot points 1 and 4 were computed using formulas for a dipping layer. An increased dip in the pre-Tertiary rocks between shot points 3 and 4 is indicated by the higher updip apparent velocity recorded from shot points 4,5 , and 6 . The depths to the same layer at shot points 5 and 6 were determined from the one-way delay times at these shot points. Evidence of a fault between shot points 4 and 5 is found in the large difference in intercept times for the pre-Tertiary velocity segments.

A possible source of error in the determination of the velocity layering between shot points 1 and 4 is in the assumed thickness of the high-velocity bed within the Cenozoic rocks. An alternate interpretation of the seismic data could be based on the assumption that the 5,700-fps layer is relatively thin and that between it and the unaltered pre-Tertiary basement is an intermediate layer (the 10,200- to 11,200 -fps layer) that is composed possibly of weathered and fractured pre-Tertiary rocks. This layer might also be a thick layer of older Cenozoic materials having high absorption properties. The existence of such a layer could possibly also explain the attenuation of the first arrivals. Any increase in the assumed thickness of the 10,200- to 11,200 -fps layer would also result in an increase in the calculated depth to the 15,600-fps layer; therefore, the indicated depths to the unaltered pre-Tertiary rocks should be considered as minimums. If the 10,200- to 11,300 -fps layer continues downward to the 15,600-fps layer basement, the depth to that layer at shot point 4 would be about 1,600 feet instead of about 900 feet.

The first interpretation of the data presented is preferred over several other possible alternatives. Because of uncertainties that exist, as well as those inherent in seismic-refraction measurements, the depths indicated in the cross section are not exact but represent what is probably the most reasonable of several possible depths by which the traveltime data can be explained.

\section{PROFILE 2}

Seismic profile 2 (pl. 3) was shot along a 42,000-foot line where the gravity measurements (pl. 1, sheet 3) 
suggested that the pre-Tertiary bedrock is several thousand feet deep at one end (shot point 1) and much shallower at the other end (shot point 5). Simultaneous recordings were made by the U.S. Geological Survey and the Seismological Laboratory of the California Institute of Technology on two spreads 5,400 feet and 1,200 feet long, respectively, separated 1,200 feet to give a combined geophone spread of nearly 8,000 feet.

Intercept formulas for two dipping layers were used to compute the depths to and the dip of the $8,600-\mathrm{fps}$ and the 15,800-fps layers beneath shot points 3, 4, and 7. Depths to the 15,800-fps layer at shot points $1,2,5$, and 6 were computed using delay times at these points. The velocity layering at shot points 5 and 6 was assumed to be the same as that beneath the geophone spread; however, measurements made by use of a shorter spread between shot points 1 and 2 revealed a 7,000-fps layer directly below the low-velocity weathered layer and a 10,000-fps layer at a depth of about 2,000 feet.

The uppermost layer of the overburden in most of the areas described is composed of dry, aerated gravels and sands having a low velocity of about 1,000 fps. The existence of this low-velocity layer is confirmed on most of the profiles by the fact that the first linear segment of the traveltime curves do not pass through the origin, even with very close spacings. For this and subsequent profiles, calculations were made assuming a weathered layer having a velocity of 1,000 fps and a depth determined primarily by the intercept time of the first linear segment of the traveltime curve. The error resulting from this assumption cannot be great, because of the shallow depths and small total traveltimes involved. The weathered layer along profile 2 is relatively thick, approximately 50 feet, as is indicated by the intercept of the 6,200-fps segments of the traveltime curve at shot points 4 and 7 .

The depths to the 15,800-fps layer may be in error by as much as 15 percent, but the subsurface configuration cannot differ much from that shown. As a check on the general reliability of the interpretation, a ray path (ABCDEFG) was constructed, and the time for a wave traveling from shot point 1 to the first geophone of the spread was calculated. The time required to travel this path would be 2.05 seconds; the recorded time was 2.13 seconds, a difference of less than 4 percent. In view of the many small uncertainties, especially in the thickness of the near-surface low-velocity layer, it would be meaningless to pursue further the cause of this discrepancy.

\section{PROFILE 3}

Seismic profile 3 (fig. 18) was shot along an easttrending road just south of Lone Pine (pl. 1, sheet 3). V. P. Gianella of the University of Nevada (written commun., 1957) earlier noted that the road is now abruptly offset about 16 feet apparently in a left-lateral direction in the zone of the earthquake fault of 1872. The position of the road offset falls directly on the trace of a fault as mapped by Willard D. Johnson in 1907 (Hobbs, 1910). This fault is the easternmost of two important faults along which movement took place in the 1872 earthquake, and evidence for it can still be seen on aerial photographs. The road is a modern oilsurfaced road so it could not have been offset in 1872 by fault movement, but its 1872 predecessor (perhaps a wagon trail or fence line) may have been offset by the earthquake. The profile was shot to determine if seismic evidence for a fault could be found in the position of the road offset. The seismic traveltime curves and the delay times at each geophone (Pakiser and Black, 1957) indicate that the depth to the 5,700-fps layer (assumed to coincide with the water table) increases from about 8 to 12 feet within 200 feet east of the third geophone from the west, which had been placed in the road offset.

Faults are known to act as ground-water barriers or dams that in many places cause depression of tho ground-water table on the down-gradient side of a fault (Robert C. Scott, oral commun., 1958). The finely ground material in a fault zone may be in part altered to clay having low permeability, and dissolved solids may be deposited in the remaining pore space in such a way that the flow of ground water through the fault zone is retarded and the water is ponded on the upgradient side. The surface water from the Sierra Nevada in this area flows eastward. Depression of the ground-water table is east of the offset and is of an amount that would be expected if a fault actually exists at the road offset.

\section{PROFILE 4}

Profile 4 (pl. 3) was located to intersect a fault scarp of late Quaternary origin described by Knopf (1918) that is approximately 3 miles east of Independence (pl. 1, sheet 3). The road along which the spread was placed makes an abrupt turn, approximately $25^{\circ} \mathrm{N}$., at the number 4 geophone position. The traveltime curves have been corrected to allow for this change in direction.

Depths to velocity interfaces at shot points 2,3 , and 4 were computed using intercept times on the assumption that interfaces are plane. A weathered layer 2-9 feet thick having a velocity of 1,000 fps was assumed in order to explain the failure of the 5,300-fps segments (shot points 2 and 3 ) and the 6,000-fps segments (shot points 1,7 , and 8 ) to pass through the origin. The 5,700 -fps velocity in the upper layer is consistent with that found elsewhere in Owens Valley and was assumed to be correct at this location. A velocity of 6,500 fps in 

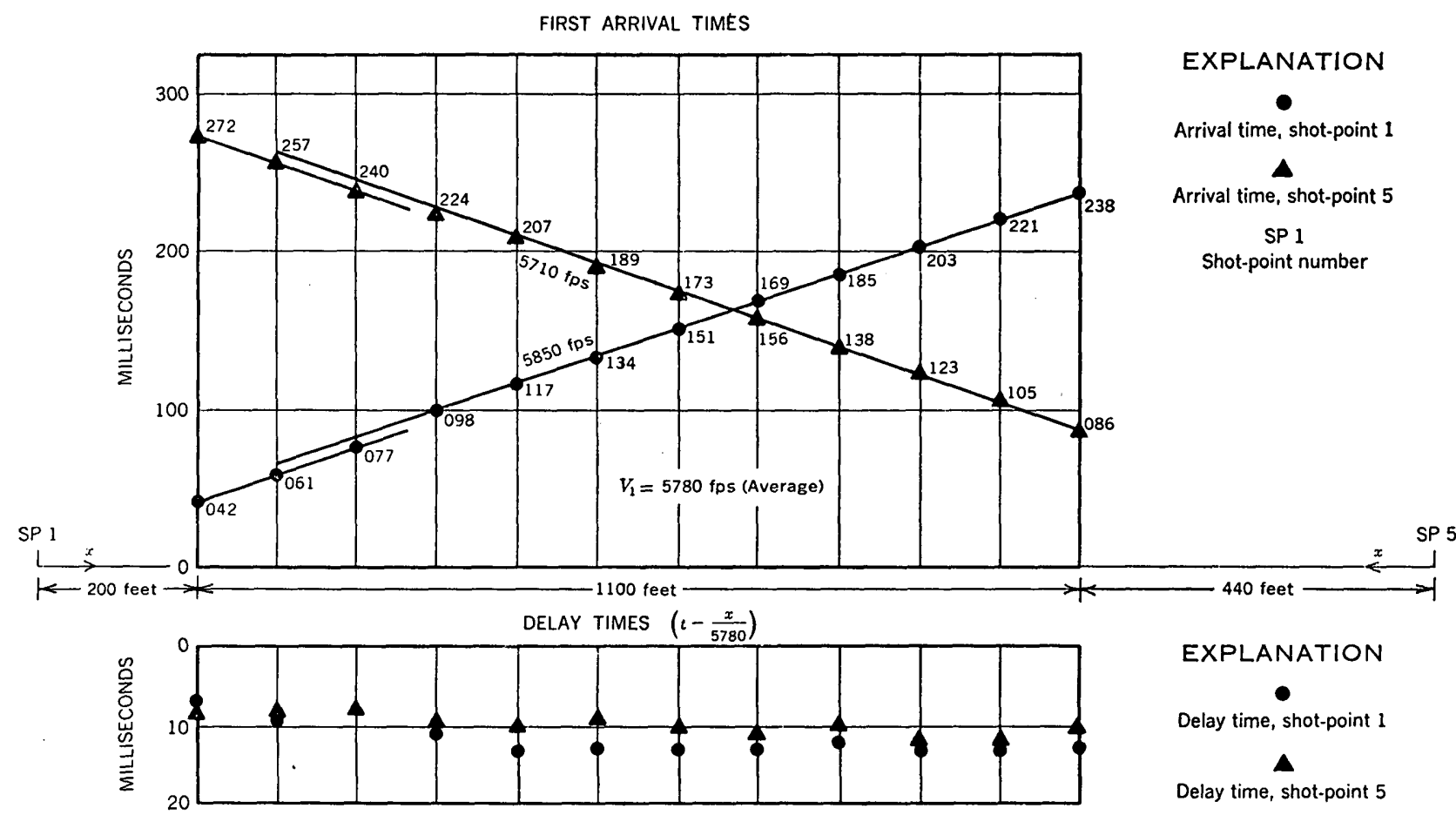

EXPLANATION

Delay time, shot-point 1

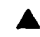

Delay time, shot-point 5

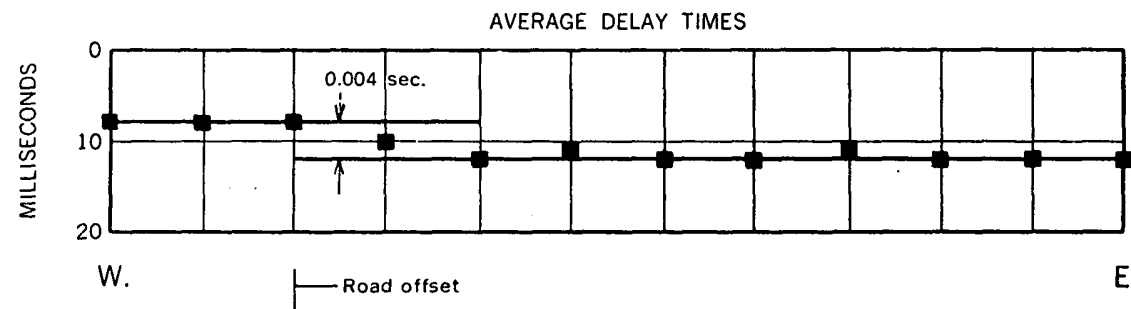

\section{EXPLANATION \\ Average delay time}

E.

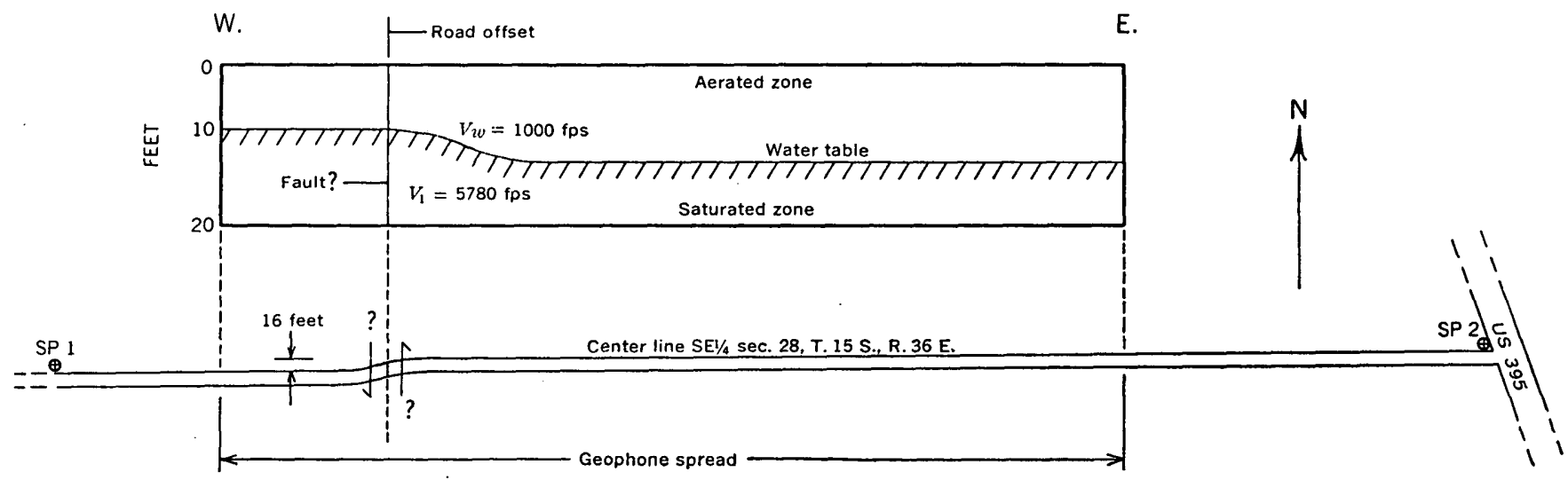

Figdro 18.-Analysis of selsmic proflle 3 at a road offset south of Lone Pine.

the layer identified as younger Cenozoic rocks was calculated from the apparent 6,300-fps downdip velocity recorded at shot points 2,3, and 4 and from the apparent 6,600 -fps updip velocity recorded at shot points 1,7 , and 8. The 7,500-fps true velocity in the older Cenozoic rocks was obtained from the apparent velocities: 7,400 fps at shot points 2, 3, 4, and 5 and 7,600 fps at shot points 8 and 9.

The velocity in the pre-Tertiary rocks has been established at other locations in Owens Valley as approxi- mately 15,700 fps. Because of the location of the geophone spread over a relatively complex structure, this velocity could not be calculated from direct- and reverse-shot data. Two apparent velocities were determined for the basement: $14,500 \mathrm{fps}$ at shot points 10 and 11 and 12,200 fps at shot points 5 and 6 . Assuming the true value of $15,700 \mathrm{fps}$ for the velocity in the pre-Tertiary rocks, the depth to basement at shot point 5 is 1,650 feet, and the dip of the pre-Tertiary surface is approximately $9^{\circ}$. The fault between shot points 5 and 6 
is inferred from the abrupt difference in intercept times of the 12,200-fps segment recorded at these shot points. The velocity layering between shot points 6 and 12 is based upon measurements taken with a short spread in this location.

A major fault is well determined at the No. 3 geophone by the discontinuities in the 14,500-fps traveltime segments, but its location on the profile could be in error by as much as 500 feet horizontally. The depth to the pre-Tertiary basement on the downthrown side was determined by extending the Cenozoic and preTertiary interface from shot point 5 to the fault at the calculated $9^{\circ}$. The corresponding interface was likewise extended eastward from shot point 9 at a calculated dip of $3^{\circ}$ to determine the depth to the pre-Tertiary basement on the upthrown side of the fault. The 32,800fps segments recorded from shot points 5 and 6 also indicate a fault. The high apparent velocity is interpreted as the result of arrivals that travel westward in the upper part of the pre-Tertiary rocks to the plane of the fault and then are diffracted upward to the westernmost three geophones. A similar but less extreme high apparent velocity breaks away from the 7,400-fps segment at shot point 4 . This discontinuity may represent diffraction from a shallower layer terminating against the fault. Records from shot points 9,10 , and 11 reveal a velocity of about $9,600 \mathrm{fps}$ that may indicate a relatively high-velocity layer within the Cenozoic section, whose upper surface is near the fault edge where the fault cuts the pre-Tertiary rock.

Another interpretation of the data is based upon the correlation of the 32,800 -fps segment as an apparent updip velocity with the 9,600 -fps segment as an apparent downdip velocity to obtain a true velocity approximately that assumed for the pre-Tertiary rocks. This would require a dip of approximately $16^{\circ} \mathrm{E}$., which could indicate a system of distributive faults about 1,500 feet wide. A second alternate interpretation is based upon the assumption that the 9,600-fps and the 12,200-fps velocities are, respectively, the downdip and updip apparent velocities of a layer within the Cenozoic section. This interpretation has been rejected primarily on geologic grounds and also because consistency between the overlapping east and west traveltime curves is difficult to obtain under this assumption.

In computing depths at shot points 7 through 11 , the intercept times were separated into delay times corresponding to the least time travel path for each shot. The 5,700- and 6,500-fps layers are required to thin to the west, and the 7,500-fps layer is required to be very near the surface to explain these delay times. The $3^{\circ}$ dip of the Cenozoic and pre-Tertiary interface east of shot point 9 was computed by assuming that the 14,500- fps segment is the apparent downdip velocity corresponding to a true velocity of 15,700 fps.

To check part of the interpretation a ray path (ABCDEF, profile 4, pl. 3) was constructed. The calculated total traveltime agrees exactly with that measured in the field.

\section{PROFILE 5}

Profile 5 (pl. 3) was run along an east-trending road $21 / 2$ miles south of Bishop (pl. 1, sheet 2). The maximum shot-point offset of the 12-geophone, 5,400-foot spread was 13,000 feet.

Depth determinations were made by use of intercept times and formulas for plane dipping surfaces. A weathered layer having a velocity of $1,000 \mathrm{fps}$ and a maximum thickness of 10 feet was assumed in making the calculations. The 5,820-fps segments recorded at shot points 1 and 3 and the 6,050-fps segments at shot points 2 and 8 yield a true velocity of $5,900 \mathrm{fps}$, which is assumed to be that in the younger Cenozoic rocks. The interface between younger and older Cenozoic rocks dips to the east beneath the spread. The 6,720-fps segment is taken as the apparent downdip velocity, and the 7,120-fps segment is taken to be the apparent updip velocity to give a true velocity of $6,900 \mathrm{fps}$. Velocity layering for the part of the profile between shot points 1 and 8 was determined using formulas for dipping beds; at shot points 3-7, one-way delay times were used.

A precise calculation of the velocity in pre-Tertiary rocks was not possible for the profile because of small irregularities in arrival times; however, a reasonable interpretation of the data is made by taking $21,600 \mathrm{fps}$ as the apparent updip velocity of the shots to the east and 12,300 fps as the apparent downdip velocity of the shots to the west. This correlation yields a true velocity of approximately $15,700 \mathrm{fps}$, which previously had been identified as that in the pre-Tertiary rocks. No quantitative interpretation was made of the traveltime curve recorded from a shot point midway between shot points 3 and 4 because of an error in the station location; however the data are included to supply additional evidence of the 12,300 fps apparent downdip velocity in pre-Tertiary rocks. The greatest computed depth to the pre-Tertiary rocks along this profile is approximately 4,800 feet (shot point 5 ). Shot point 5 is evidently in the fault zone along the front of the White Mountains. This depth together with those calculated at shot points 6,7 , and 8 are assumed to be minimum depths, and the true depths may be 500-600 feet greater than those indicated on the profile. This conclusion is based on the probability that the velocity in the older Cenozoic rocks east of the spread increases with depth.

Gravity data (pl. 1, sheet 2) indicate that the thickness of the sedimentary rocks increases to the south. 
Measurements taken along a profile 3 miles south of and parallel to profile 5 failed to indicate any pre-Tertiary rock even though a maximum shot-point offset of 17,000 feet was used. By assuming a velocity of 15,700 fps in pre-Tertiary rocks and making further limiting assumptions, the greatest depth to the Cenozoic and preTertiary interface is determined to be at least 6,400 feet and possibly more. The east dip of the basement interface shown on profile 5 corresponds closely to that inferred from the gravity data (fig. 11).

\section{PROFILE 6}

Profile 6 (pl. 3) was shot in Long Valley using a 12geophone spread 5,400 feet long (pl. 1, sheet 1). Neither the spread nor the shot points lie on a straight line; however, the true shot-to-geophone distances were determined, and the necessary corrections in the traveltime curves were made.

A thin weathered layer having a velocity of 1,000 fps was assumed in calculating depths. The velocity in the younger Cenozoic rocks was determined from the 4,900-fps segment recorded from shot point 1 by assuming an equal intercept time at shot point 5 to give a velocity segment of $5,200 \mathrm{fps}$ from that shot point. The true velocity of 5,000 fps thus determined is not exact, but the error cannot be great. The 5,700fps segment, assumed to be the apparent downdip velocity in the older Cenozoic rocks, is consistent over three traveltime segments, two of which are of second arrivals. This segment is correlated with the 6,300fps segment recorded from shot point 5 to yield a true velocity of $6,000 \mathrm{fps}$. The 5,000-fps layer becomes thinner to the south, and beyond shot point 2 the older Cenozoic rocks were assumed to be very near the surface.

The 10,000-fps high-velocity layer is assumed to be volcanic rock, probably rhyolite that correlates with the rhyolite near the center of Long Valley and with the rhyolite of Glass Mountain; the rock is undoubtedly complexly faulted, and its upper surface is highly irregular, as indicated by the seismic data. The locations of the individual faults as well as their displacements should be considered as a schematic presentation of the probable structural features rather than an exact description. Although the irregular surface of this high-velocity layer scatters the traveltime data considerably, a fairly reliable determination of velocity is made by correlating the 9,200 -fps and 11,800 -fps segments as apparent velocities to yield a true velocity of approximately $10,000 \mathrm{fps}$. The faults on either side of shot point 5 and the fault between shot points 1 and 2 were inferred from delay times at the shot points; the surface profile of the 10,000 -fps layer under the spread was calculated using the delay times at each geophone (Pakiser and Black, 1957).

The 31,200-fps velocity recorded for shot point 4 is believed to represent an apparent updip velocity along a tilted block having a 10,000-fps velocity. The travel path of seismic waves from shot point 4 is greatly different from that from shot points 1,2, and 3. This difference in travel paths may explain the failure of the 31,200-fps segment to appear on other traveltime curves. Another explanation is possible: the arrivals may have been refracted off a vertical interface, such as a major fault, that bounds the area worked; however further data would be required before reaching a definite conclusion. As a test of the interpretation, ray paths. (ABCDEFG and $\mathrm{A}^{\prime} \mathrm{B}^{\prime} \mathrm{C}^{\prime} \mathrm{D}^{\prime} \mathrm{E}^{\prime} \mathrm{F}^{\prime} \mathrm{G}^{\prime}$, profile 6, pl. 3) were constructed. Over both paths the computed and the observed travel times agree very closely.

Gravity data (pl. 1, sheet 1 ) rule out the possibility that the 10,000-fps layer could be pre-Tertiary rock.

The results of six seismic-refraction profiles shot in Mono Basin by the Seismological Laboratory of the California Institute of Technology were presented in an earlier report (Pakiser and others, 1960). Part of the data included here also was previously described and interpreted (Kane and Pakiser, 1961).

\section{GEOLOGIC INTERPRETATION OF GEOPHYSICAL SURVEYS}

\section{STRUCTURAL GEOLOGY OF OWENS VALLEY REGION}

A nearly complete, if necessarily somewhat generalized, description of the Cenozoic structural geology of the Owens Valley region can now be presented from: the preceding review of the geology of the Owens Valley region and from the detailed presentation of the results of the gravity, magnetic, and seismic investigations. In this discussion, large-scale structural features having regional significance are emphasized. As a result of the geophysical studies, the structure of three major downdropped blocks is now rather fully known. These are Mono Basin, Long Valley, and Owens Valley.

The discussion of the gravity and seismic profiles and the gravity contour maps clearly indicates that zones of steep gravity gradient mark zones of faulting along which the Cenozoic rocks have been displaced relatively downward against pre-Tertiary rocks. The amplitude of the gravity-minimum anomalies over areas covered by Cenozoic rocks is a guide to the thickness of these rocks. The magnitude of the steepest gradient is a guide to the dip of the bounding faults. The gravity profiles $\left(A-A^{\prime \prime \prime}\right.$ to $H-H^{\prime}$, figs. $\left.6-15\right)$ and the seismic profiles (figs. 17,$18 ;$ pl. 3 ) are lines along which information on the depth and configuration of the Ceno- 
zoic and pre-Tertiary interface is controlled. It is a relatively simple task to extrapolate the subsurface configuration from these lines along zones of steep gravity gradient. Thus the subsurface structure of Mono Basin, Long Valley, and Owens Valley has been determined with an accuracy sufficient for reconnaissance purposes.

\section{MONO BASIN AND LONG VALLEY}

The structure of Mono Basin has been previously described by Pakiser, Press, and Kane (1960) and is only briefly summarized here. Mono Basin is a large, roughly rectangular block that has subsided in two parts and has received a maximum accumulation of about $18,000 \pm$ 5,000 feet $(5.5 \pm 1.5 \mathrm{~km})$ of low-density sediments and volcanic deposits of Cenozoic age (pl. 1, sheet 1$)$. The block is bounded by vertical or near-vertical faults, and although these faults in general conform to the physiographic outline of the basin, they are found basinward from the physiographic escarpments. The basin is divided into two parts: (1) a roughly triangular block forming the southwestern half, which has subsided to the maximum depth of about 18,000 $\pm 5,000$ feet and (2) the block forming the northeastern half, which has subsided only about one-third that much. The northeastern half, only partly shown on the map (pl. 1, sheet 1), was described more fully in the earlier paper. These two blocks are almost completely separated by a triangular salient that projects northwestward from the southeastern boundary of Mono Basin.

The structure of Long Valley is of the same type as Mono Basin (pl. 1, sheet 1). The valley is a closed basin, bounded on its entire perimeter by vertical or near-vertical faults. The locations of these faults are defined by the steepest gravity gradients along the nearly elliptical outline of the Long Valley block. Segments of this outline are obviously straight lines (for example, the bounding fault on the south and parts of the bounding fault system on the north and northwest). Parts of the system of bounding faults may be curved, however (for example, the eastern arc of the structure), or these parts may consist of a series of short line segments that approximate a curve. If the perimeter of the Long Valley block as defined by its bounding faults consists of short line segments, it would be a polygon approximating an ellipse.

The part of the Long Valley block outlined by the eastern arc, approximately the eastern one-third, subsided to a maximum depth of $18,000 \pm 5,000$ feet (5.5 \pm $1.5 \mathrm{~km}$ ) below the surface-approximately $11,000 \pm 5,000$ feet below sea level-and received a thick accumulation of light sediments and volcanic deposits of Cenozoic age (figs. 8 and 9). Mono Basin subsided about the same distance to a level below sea almost identical with that of
Long Valley (fig. 9). (See also Pakiser and others, 1960.) The pre-Tertiary floor of the Long Valley block slopes gently eastward from the Sierra Nevada front to reach the maximum depth about 5 miles west of the extreme eastern limit of the bounding fault system (fig. 8). A system of distributive faults has been inferred in this zone of gentle slope, but warping could explain the gentle slope as well.

The maximum width of the Long Valley block is about 9 miles; the length is 19 miles. The area of the block is about 150 square miles. Thus, if the average depth of the Cenozoic deposits is estimated to be $21 / 2 \pm 1$ miles, the volume of the rocks contained in the basin is about $375 \pm 150$ cubic miles.

The Cenozoic rocks and the pre-Tertiary rocks are in fault contact throughout the entire fault system bounding the Long Valley block, and the faults of this system are either vertical or very nearly vertical. Therefore, almost the entire section of Cenozoic rocks has been displaced against the older rocks by faulting. The displacement could have happened in only two possible ways: Either the entire Cenozoic section accumulated before faulting displaced it against the preTertiary rocks, or fault movements took place nearly concurrently with deposition and the lighter Cenozoic deposits were displaced against faults soon after they were laid down. The first possibility can be ruled out with confidence, and so, fault movements are concluded to have been almost continuous or repeated frequently throughout the time of deposition of the Cenozoic section. This interpretation is supported by the seismic evidence of layers within the Cenozoic section in Owens Valley that have been displaced much less by faults than has the pre-Tertiary floor (see, for example, pl. 3); presumably, subsidence in Long Valley was similarly prolonged.

The gravity high near the center of the Long Valley block and the corresponding magnetic anomaly have been interpreted as an expression of a complex pile of intrusive and extrusive volcanic rocks having high density and high magnetic susceptibility composed probably of basalt or mafic andesite. A similar gravity high was found in Mono Basin (Pakiser and others, 1960).

Some local structural features of interest are revealed by the gravity contours in the Long Valley area. The Hilton Creek fault, mapped by C. D. Rinehart and D. C. Ross (written commun., 1956), is shown by the gravity contours to extend a few degrees west of north to meet the southern bounding fault of the Long Valley block (pl. 1, sheet 1). The gravity low trending southeastward from the Long Valley minimum approximately along the course of Owens River probably rep- 
resents a thick accumulation of the Bishop tuff of Gilbert and, perhaps, other low-density rocks of Cenozoic age. The low-density deposits may have been laid -down in a mature predecessor of the present youthful valley of Owens River in the area of the Volcanic Tableland. Rinehart and Ross (1957) concluded that a Pleistocene lake may have been ponded by the Bishop tuff and that the lake later broke out and the southeastward-flowing Owens River cut the deep Owens River Gorge, perhaps at a time of uplift of the Volcanic Tableland. South of the Owens River Gorge, deflections in direction of the gravity contours are seen to correlate with mapped and inferred faults (pl. 1, sheet 1). The negative departure of the gravity field near the faults is probably caused by moderately thick accumulations of alluvium. Anomalies of this type are clearly evident along the northern end of Wheeler Crest. Many of the smaller alluvium-filled valleys that flank small basin ranges east of Long Valley are expressed as gravity minimums. The most marked of these is the gravity low west of the southern end of the Benton Range. Similar small gravity anomalies in the Mono Basin area were previously described by Pakiser, Press, and Kane (1960).

\section{OWENS VALIEY}

The Owens Valley structure as defined by the geophysical survey extends for more than 100 miles a few degrees east of south along and west of nearly the entire length of the White and Inyo Mountains (pl. 1). Except on the extreme south, the east fault zone bounding the deepest depression of the Owens Valley structure forms a common boundary with the White and Inyo Mountains. The west boundary of the valley block is generally east of the Sierra Nevada front, and the complexity of the structure along the Sierra Nevada front, as revealed by the geophysical survey, is in marked contrast to the relative simplicity of the structure along the White and Inyo Mountains front. In the latitude of Long Valley, the westernmost fault bounding the Owens Valley structural basin is about 35 miles east of the Sierra Nevada. In the latitude of Owens Lake, the Sierra Nevada and the Owens Valley structural basin share a common boundary.

The east fault bounding the Owens Valley structural basin is defined by the zone of steep gravity gradients along the White and Inyo Mountains (pl. 1). It extends a few degrees east of south without interruption for about 50 miles from its northern limit east of the southern end of Blind Spring Hill to a point east of Red Mountain (pl. 1, sheets 1 and 2). Along this segment of the fault zone, the Cenozoic rocks of Owens Valley are everywhere in fault contact with the preTertiary rocks of the White Mountains. Analysis of selected gravity profiles indicates that the fault dips very steeply and may be vertical (figs. 8, 11, and 12). The greatest depth to the pre-Tertiary floor of Owens Valley west of this fault is found from interpretation of these gravity profiles to be $8,000 \pm 2,000$ feet. Interpretation of the seismic-refraction profile south of Bishop (pl. 3) reveals that the greatest depth to preTertiary rocks at the eastem end of this profile is more than 4,800 feet. If an undetected (and probable) section of higher velocity Cenozoic rocks exists under the eastern part of this profile, the depth could be considerably more than 5,000 feet. The seismic line is in an area where the residual gravity relief is less than that along gravity profile D-D' (pl. 1, sheet 2); therefore, the depth to pre-Tertiary rocks should be correspondingly less. The thickness of the Cenozoic section in the general area of Bishop is probably about 5,000 feet and increases to the north and south to about 8,000 feet. The correspondence between the gravity and seismic results is good within the range of uncertainty of \pm 25 percent.

East of Red Mountain the east fault zone bounding the Owens Valley structure is abruptly offset to the west by a short fault; south of the fault, the zone continues 60 miles without interruption (pl. 1, sheets 2 and 3). The short fault east of Red Mountain trends a few degrees north of east at right angles to the main fault. It is defined by a steep gravity gradient that indicates a steep, perhaps vertical, dip.

Immediately south of this offset the gravity minimum anomaly of Owens Valley is extremely narrow and almost disappears (pl. 1, sheet 3). But in the latitude of Independence it is once more clearly defined; it becomes broader and more pronounced farther south (pl.1, sheet 3). The pre-Tertiary floor in the narrow wedge north of Independence must be relatively shallow, perhaps 1,000 or 2,000 feet. Analysis of the gravity data (figs. 14 and 15) indicates that the thickness of Cenozoic rocks in fault contact with the pre-Tertiary rocks of the Inyo Mountains south of Independence is about 8,000 $\pm 2,000$ feet; the fault dips steeply and may be vertical. The seismic-refraction profile east of Independence on interpretation revealed a depth to pre-Tertiary rocks of about 3,000 feet (pl. 3). In the Owens Lake basin, the seismic-refraction profiles indicate a thickness of Cenozoic rocks of about 6,000 feet (pl. 1 , sheet $3 ; \mathrm{pl} .3$ ), but none of the profiles was so located as to reveal the maximum thickness; therefore, the seismic and gravity results on the depth to pre-Tertiary rocks are again in good agreement within the uncertainty range of \pm 25 percent.

A few miles southeast of Independence, a branch of the main east fault bounding the Owens Valley struc- 
tural basin trends almost due north from its intersection with the main fault (pl. 1, sheet 3). The existence of the branch fault, which may continue farther north than shown, is based on both gravity (pl. 1, sheet 3 ) and seismic-refraction evidence (pl. 3). Near Keeler, another branch fault trends south from its intersection with the main fault, and the main displacement of Cenozoic against pre-Tertiary rocks took place on this fault (fig. 17 ; pl. 3). A complex system of faults diverges from this fault to form the southeastern boundary of the Owens Lake basin and of the narrow extension of the basin to the south (pl. 1, sheet 3). This narrow extension shown on the extreme south of the map, presumably continues farther south to join Rose Valley. The main bounding fault of the Inyo Mountains curves to the east and is terminated in Lower Centennial Flat (pl. 1, sheet 3).

The existence of the southwestward-trending fault just southeast of seismic profile 2 (pl. 1, sheet 3 ) is based on gravity evidence; the refracted waves in this segment of the seismic profile (pl. 3) may have traveled at shallow depths along this fault or from the relatively shallow pre-Tertiary floor of the Owens Lake basin along this line. The horizontal distance from the seismic profile to this fault is just about the same as the computed depth to pre-Tertiary rocks; therefore, the waves may have been refracted nearly horizontally from the shot points to the fault and thence to the geophone spread.

The main west fault bounding the Owens Lake basin as defined by the steep gravity gradient (pl. 1, sheet 3) coincides with the Sierra Nevada front, and interpretation of gravity profile $\mathrm{H}-\mathrm{H}^{\prime}$ (fig. 15) suggests that the displacement is distributed between two parallel faults, the easternmost of which is about 2 miles east of the Sierra Nevada. The areal geology and gravity contours reveal that the westernmost fault bounding the Owens Lake basin is displaced sharply to the east by three or more short faults trending a few degrees south of east (pl. 1, sheet 3 ; see also Kane and Pakiser, 1961). South of these short faults, the Owens Valley structural basin forms a deep, narrow channel into Rose Valley. The western bounding fault system of the deepest part of the Owens Valley structural basin north of the Owens Lake basin is everywhere found east of the Sierra Nevada front (pl. 1).

The west fault system bounding Owens Valley as revealed by the gravity data (pl. 1, sheet 3 ; fig. 14) forms a common boundary with the eastern front of Alabama Hills, and the dip of the main fault is very steep, perhaps vertical. This fault continues a few degrees west of north for nearly 10 miles beyond the outcrop of preTertiary rocks in Alabama Hills (pl. 1, sheet 3). The structural feature including Alabama Hills thus ex- tended is seemingly terminated on the north by a short fault or system of short parallel faults trending at right angles to the main fault. The exposed Alabama Hills may also be terminated by a short fault on the north. The deflection of the gravity contours on the southern end of Alabama Hills clearly reveals that the structural feature is terminated there by a short fault (pl. 1, sheet 3).

North of the buried extension of Alabama Hills, the main fault continues to join the fault trending a few degrees west of north from the latitude of Independence. This fault was mapped by Knopf (1918) and is shown on the map (pl. 1, sheet 3). Northwest of Independence, the thickness of the Cenozoic rocks is relatively small, perhaps 1,000 or 2,000 feet. The westernmost fault bounding the Owens Valley structural basin continues beyond Big Pine to the north and passes into a warp or system of distributive faults about 3 miles north of Crater Mountain (pl. 1, sheet 2; fig. 12). North of the end of the main bounding fault, the gravity data (pl. 1, sheet 2; fig. 11) show that the Sierra Nevada front is downwarped. This conclusion is verified by seismicrefraction profile 5 (pl. 3) and by geologic mapping (P. C. Bateman, written communication, 1956). The feature thus defined has been designated the Coyote Warp by Bateman (written communication, 1956).

The block of pre-Tertiary rocks known as Poverty Hills (pl. 1, sheet 2) is directly on the main western bounding fault in a position that is seemingly anomalous if the main fault is continuous in this area. This block is postulated to be a gravity slide that broke loose from the higher slopes of the Sierra Nevada and moved downslope to a position at rest in its present location, where it was partly buried by low-density sediments. This postulation explains its contradictory location with respect to the main fault trends.

North of Tungsten Hills and northwest of the main part of Owens Valley, the Owens Valley structure branches into the west-trending synclinal downwarp and subordinate faulting, as revealed by the gravity data (pl. 1, sheet 2; fig. 13). The axis of this downwarp is buried under the Bishop tuff of the Volcanic Tableland and trends into Round Valley. The gravity data are too few to define reliably the nature of the Cenozoic and pre-Tertiary interface along Wheeler Crest, but the interface is probably a fault contact; fault segments and springs have been mapped there by P. C. Bateman (written communication, 1956). The Cenozoic section is probably relatively thin in this area. The small gravity high whose axis trends northeastward from the Sierra Nevada front along Pine Creek may represent a buried extension of a relatively dense glacial moraine (pl. 1, sheet 2). Many of the small 
irregularities of the gravity contours in the area surrounding Tungsten Hills may have local geologic significance, but they are not analyzed here.

The Owens Valley structural basin thus defined is seen to be bounded by a single fundamental fault or narrow fault zone having only one dislocation along most of the western front of the White and Inyo Mountains. Along the eastern front of the Sierra Nevada, the boundary of the Owens Valley structural basin consists of a complex system of alternating faults and warps, and the faults are in general found east of the Sierra Nevada front. The Owens Lake basin is bounded by a complex system of steeply dipping or vertical faults, and north of Tungsten Hills the Owens Valley structural basin branches into a synclinal downwarp. The main, linear structure of Owens Valley continues north to the southern end of Blind Spring Hill. A subdued extension of the Owens Valley structural basin probably continues farther north around the northern end of the White Mountains.

\section{NATURE OF CENOZOIC ROCKS}

The regional Cenozoic structural features of Owens Valley, Long Valley, and Mono Basin have been described. Before a comprehensive analysis of the origin of these structural features and of some of the rocks associated with them, the nature of the rocks of Cenozoic age that are confined within these deeply depressed structures must be considered. Much information can be obtained by examination of the upper, exposed surface of these rocks, and it is important to emphasize that some information in three dimensions is obtained by geologic mapping. This surface is not a plane surface; it generally ranges in altitude from 4,000 feet in the Owens Lake basin to 8,000 feet in the mountain slopes adjacent to Long Valley and Mono Basin. The exposed surface of the rocks is described, and this description is based on the work of others as cited. In addition, some information on the nature of these rocks can be inferred from gravity, magnetic, and seismic measurements and from a consideration of the relative volumes of the depressed structural features and of the self-evident available sources of the rocks contained in them (Pakiser and others, 1960).

The inferred nature of the Cenozoic rocks of Mono Basin was described in a previous report by Pakiser, Press, and Kane (1960), who concluded that the rocks consist of stream-transported sediments and materials that are of volcanic origin and have a low average density. The rocks of Cenozoic age were shown to be divided into two units on the basis of seismic velocity: (1) a shallow layer having a relatively low velocity that may represent mostly unconsolidated clastic de- posits of Pleistocene(?) and Recent ages and (2) a deeper layer having a higher velocity that may represent rather well-indurated sedimentary and volcanic rocks of late Tertiary (?) and perhaps early Pleistocene (?) ages. By means of an erosion-deposition budget, about two-thirds of the approximately 300 cubic miles of Cenozoic rocks in Mono Basin were also shown to be probably of volcanic origin (Pakiser and others, $1960)$.

\section{CENOZOIC ROCKS OF LONG VALAEY}

Geologic mapping (Gilbert, 1938, 1941; C. D. Rinehart and D. C. Ross, 1957, and written commun., 1956), had shown that the Cenozoic rocks of Long Valley include stream deposits, lake beds, glacial debris, and volcanic pyroclastic and flow rocks that range in composition from basalt to rhyolite (pl. 1, sheet 1). The gravity data show only that the Cenozoic rocks of Long Valley are significantly lower in density than the pre-Tertiary rocks; the density is probably about $2.3 \mathrm{~g}$ per $\mathrm{cm}^{3}$, which corresponds closely to the average density of the rocks revealed by geologic mapping.

The single seismic-profile shot in Long Valley (pl. 3) reveals a velocity layering similar to that in Mono Basin. Directly beneath the near-surface low-velocity-weathered-layer, a layer of younger Cenozoic deposits having a velocity of $5,000 \mathrm{fps}$ was found. The deposits are probably predominantly unconsolidated lake beds and stream deposits, but some products of explosive volcanic eruptions may also be present. At a depth ranging from a few hundred to 1,000 feet, a layer having a velocity of $6,000 \mathrm{fp}_{\mathrm{s}}$ was discovered. The layer is probably a more highly consolidated variety of the deposits lying above it. The shallow layer having a velocity of $5,000 \mathrm{fps}$ is probably made up of virtually unconsolidated clastic deposits of Pleistocene(?) and Recent ages. The layer having a velocity of 6,000 fps is probably composed of materials of the same type but of late Tertiary(?) and perhaps early Pleistocene (?) ages.

A layer having a velocity of $10,000 \mathrm{fps}$ was found beneath the 6,000-fps layer at depths ranging from 1,000 to 3,000 feet (pl. 3). The 10,000-fps layer is complexly faulted and probably represents a buried flow that is composed probably of rhyolite and may correlate with the rhyolite exposed near the center of Long Valley and with the rhyolite of Glass Mountain. C. D. Rinehart (written commun., 1958) inferred that these rocks were buried in the Long Valley structure; seismic data seem to support that inference. No compelling evidence for a buried extension of the Bishop tuff was found during the geophysical study, but Rinehart believed that the 6,000 -fps layer may represent the tuff. 
In a previous report Pakiser, Press, and Kane (1960) showed that the volume of Cenozoic rocks in Mono Basin may range from 200 to 400 cubic miles and that the volume of stream-transported sediments deposited there from pre-Tertiary rock sources may range from 0 to 200 cubic miles. These lower and upper limits of the volume of stream-transported sediments cover a wider range and are less restrictive than the true greatest lower and least upper limits, but if they are assumed to be the limits, the following can be concluded: If the maximum amount of eroded material had been supplied to a Mono Basin having a minimum volume, a balanced erosion-deposition budget could have been maintained without requiring volcanic material to make up the deficit. On the other hand, if the minimum amount of eroded material had been transported to a Mono Basin having a maximum volume, all the material deposited in the basin would have been of volcanic origin. But if the probable amount of eroded material (100 cubic miles) had been deposited in a Mono Basin having a probable volume of 300 cubic miles, a deficit of 200 cubic miles remained which would have been made up by material of volcanic origin. The same type of analysis can be applied to Long Valley with similar results.

The volume of Cenozoic rocks confined in the Long Valley structural basin ranges from 225 to 525 cubic miles, and the probable volume is 375 cubic miles. The maximum amount of material that could have been removed by erosion from the highlands surrounding Long Valley multiplied by the density ratio of pre-Tertiary and denser volcanic rocks and the assumed density of the same materials as sediments $(2.7 / 2.3)$ is 300 cubic miles; this value yields a surplus of 75 cubic miles that would have been transported out of the Long Valley area by streams if a minimum volume of the structural basin is assumed (225 cubic miles). However, at least one-third of the stream-transported sediments in Long Valley would have been eroded from Cenozoic volcanic source areas (pl. 1, sheet 1 ); so, if 200 cubic miles is taken as the maximum volume of sediments to have been eroded from pre-Tertiary sources (mainly from the Sierra Nevada), an almost perfect balance between the volume of the structure and the volume of sediments of pre-Tertiary origin is obtained.

The maximum amount of eroded material was found by assuming that the crests of the mountains surrounding Long Valley once extended horizontally to meet vertical bounding faults and the difference between this surface and the present surface shown on topographic maps represents the maximum amount of material removed by erosion. The probable amount was taken as half the maximum on the assumption that warping and distributive faulting accounted for part of the deformation and that the bounding faults may be not vertical but steeply dipping normal faults. The minimum, assuming no erosion whatever, was zero.

If the minimum amount of stream-transported material ( 0 cubic miles) was supplied to a Long Valley structural basin having a maximum volume (525 cubic miles), all the material buried in the structural basin would be volcanic in origin. But if the probable amount of stream-transported material (150 cubic miles) was supplied to a Long Valley structural basin having the probable volume of 375 cubic miles, then a deficit-balancing volume of 225 cubic miles of material of volcanic origin must be confined in the Long Valley structural basin. Perhaps a third of the 150 cubic miles of streamtransported material may be of volcanic origin. Then, one-half or more of the Cenozoic rocks contained in the Long Valley structural basin may have been erupted or intruded directly into the subsiding basin from nearby volcanic sources. Indeed, the aeromagnetic and gravity data revealing a large pile of volcanic material of rather mafic composition buried near the center of Long Valley and the direct observation of a large amount of volcanic material at the surface indicate with certainty that a large fraction of the Cenozoic rocks of Long Valley are volcanic in origin.

\section{CENOZOIC ROCKS OF OWENS VALLEY}

The description of the Cenozoic rocks as they appear on the surface of Owens Valley is taken from the work of others, mainly Knopf (1918). Stream deposits and lake beds predominate, but the deposits contain some accumulations of pyroclastic debris. Also, Pleistocene glacial moraines project downward into Owens Valley from Sierra Nevada valleys. Kane and Pakiser (1961) made an analysis of the effects of changes in the degree of sorting on the density of the Cenozoic rocks of Owens Valley and on the reliability of gravity interpretations based on the assumption of a uniform contrast in density between the Cenozoic and pre-Tertiary rocks. The aeromagnetic (pl. 2; fig. 16) and the gravity data (pl. 1 , sheet 2), indicate that a large pile of volcanic material (probably basalt) or an intrusive mass is possibly buried in northern Owens Valley northeast of Bishop. Basalt flows are exposed in many places along the Sierra Nevada front and in the southern Inyo Mountains.

The seismic-refraction traveltime curves (figs. 17 and $18 ;$ pl. 3) reveal velocity layering similar to that occurring in Long Valley and Mono Basin. A near-surface layer having a velocity ranging from 5,700 to 7,000 fps was found under the low-velocity weathered layer at almost all seismic-refraction profiles. This layer probably represents unconsolidated or semiconsolidated 
clastic sediments of late Pleistocene(?) and Recent ages. Beneath this layer, generally at a depth of about $1,000-2,000$ feet, is a layer having a velocity ranging from 6,500 to $10,000 \mathrm{fps}$. On most of the seismic traveltime curves, only these two layers were found to occur above the pre-Tertiary basement, but a thin layer having a higher velocity (10,200-11,200 fps), interpreted as a basalt flow, was found at seismic profile 1 (fig. 17) southeast of Owens Lake. And at seismic profile 4, east of Independence, a much more complex velocity layering was found (pl. 3). At least three and probably four layers, in which the velocities increase with depth, were found above the pre-Tertiary floor. Along seismic profile 4 (pl. 3) the velocity of the near-surface Cenozoic layers was found to grade markedly from lower velocity near the deepest part of the depressed Owens Valley block to higher velocity to the east and west near the fronts of the Inyo Mountains and the Sierra Nevada. The complex velocity layering in the deepest part of the Owens Valley structure along this line and the lateral gradations in velocity of the layers near the surface must reflect a more complex history of structural deformation than elsewhere in Owens Valley, for the climatic conditions, which may also affect the rate of deposition and lithification-and thus the velocitymust have been relatively constant in Owens Valley over a given interval of geologic time.

The velocity boundary across which the velocity changes from the range of 5,700-7,000 fps to the higher range of 6,500-10,000 fps is characteristic of the entire Owens Valley region including Mono Basin. This boundary is found typically at depths ranging from about 1,000 to 2,000 feet. In general, the dip of this boundary is in the same direction and less than the dip of the deeper Cenozoic and pre-Tertiary interface, and where the boundary has been displaced by faulting, the displacement is invariably less than the displacement of the deeper bedrock. Thus, seismic evidence indicates that faulting and warping were continuous or repeated at short intervals concurrently with deposition of the Cenozoic rocks, a conclusion that was independently reached from interpretation of the gravity data.

The older Cenozoic rocks having a high velocity must be more highly indurated than the younger rocks having a low velocity, which are probably virtually unconsolidated. The boundary between the rocks in Owens Valley, as in Long Valley and Mono Basin, may represent either an abrupt change in the rate of deposition, lithification, or both. Therefore the velocity boundary may represent a boundary in time in which either an abrupt climatic change or a renewed uplift of the mountain masses, or both, occurred. This boundary in time may be at or near the time of greatest uplift of the
Sierra Nevada in late Pliocene and early Pleistocene times.

\section{TECTONICS AND VOLCANISM OF OWENS VALLEY}

As may be readily perceived, analysis has progressed from using observed facts (the mapped areal geology, measured gravity and magnetic fields, measured seismicrefraction traveltimes, and the present physiography as shown on topographic maps) to making interpretations of progressively increasing uncertainty. The horizontal positions of the major faults as determined from gravity data are known with a high degree of certainty; the dips of the faults are less well known. The thicknesses of the Cenozoic rocks are known within \pm 25 percent; two independent lines of evidence-the gravity field and the seismic-refraction data-were used to make these deductions. The deductions on pages 52 and 53 on the nature of Cenozoic deposits involve a wide range of uncertainty, but the limits of this range of uncertainty are known and have been discussed. The general conclusion that a large volume of material of volcanic origin is buried in Long Valley and in Mono Basin is based on several lines of evidence, each of whichexcept the direct observation of volcanic material on the surface-involves its own uncertainty. Nevertheless, the conclusion seems to be required by the evidence at hand.

Up to this point, the presented conclusions are based on facts or on direct interpretations of facts. In the following pages, in order to arrive at some conclusions on the tectonics of the Owens Valley region and the volcanic activity there (especially in the Long Valley and Mono Basin volcanic centers), some speculations that are not directly supportable by these facts are made without contradicting these facts, and the conclusions are necessarily uncertain.

\section{DIP-SLIP FAULTING IN OWENS VALLEY}

Great vertical movement along the faults in the Owens Valley region has been conclusively demonstrated. The total vertical displacement of the preTertiary erosion surface in the latitude of Mount Whitney must have been about 19,000 feet. This is approximately the difference in altitude between the summit of Mount Whitney and the buried pre-Tertiary floor of Owens Valley east of Lone Pine. The total vertical displacement in the area of Long Valley and Mono Basin may have been more-as much as 24,000 feet from the crest of the Sierra Nevada to the deeply buried preTertiary floors of Long Valley and Mono Basin. Much of these great vertical displacements took place along the main faults bounding Owens Valley, Long Valley, and Mono Basin, but large fractions of the displace- 
ments may have been distributed among systems of closely spaced faults. Warping certainly accounts for some of the displacements.

The Sierra Nevada in the Owens Valley region is in general a westward-tilted block. The basin ranges east of Owens Valley, at least as far east as Death Valley, are eastward-tilted blocks. Therefore, Owens Valley seems to lie near the crest of a great arch that has been broken by block faulting (P. C. Bateman, written commun., 1958). As the crest of the arch broke, perhaps during general uplift of the Sierra Nevada and of the extreme western Great Basin, Owens Valley seemingly subsided as a graben. Other valleys east of Owens Valley may be merely alluviated areas on the lower ends of eastward-tilted blocks such as the Coso, Argus, Panamint, and Funeral Ranges (P. C. Bateman, written commun., 1958).

\section{STRIKE-SLIP FAULTING IN OWENS VALLEY}

Significant, but not extremely large, strike-slip movements undoubtedly took place also in Owens Valley, but the published record on the Owens Valley earthquake of 1872 is so ambiguous and contradictory that it cannot be assumed to be known whether the strikeslip movement was right lateral or left lateral, as Richter (1958, p. 499-503) showed. Gianella (1959), after a review of the literature and investigation in the field, concluded that the available evidence "indicates that the dominant horizontal movement was left lateral."

Whitney and an accompanying party visited Owens Valley soon after the earthquake of March 26, 1872. Following the visit, Whitney $(1872$, p. 138) wrote:

There are several places in the valley where fissures in the ground have crossed roads, ditches, and lines of fences, and where evidence has been left of an actual moving of the ground horizontally, as well as vertically. One of these instances of horlzontal motion is seen on the road from Bend City [Kearsarge], to Independence, about three miles east of the latter place. Here, according to a careful diagram of the locality, drawn by Captain Scoones, it appears that the road running east and west has been cut off by a fissure twelve feet wide, and the westerly portion of it carried eighteen feet to the south. The same thing was noticed by us at Lone Pine and Big Pine, with respect to fences and ditches, the horizontal distance through which the ground had been moved varying from three to twelve feet.

V.P. Gianella (written communication, 1957) stated:

Because of the above statement, $I$ have visited the area east of Independence and, from visual estimates, but without careful measurements, the relative accuracy of the above statement was confirmed. There the horizontal movement was certainly leftlateral of about the magnitude stated by Whitney.

Unfortunately, the diagram of Captain Scoones was not published by Whitney, nor did Whitney present any diagrams of actual measurements or photographs supporting his conclusion.

Some years later, in 1883 , G. K. Gilbert visited Owens Valley and he wrote (Gilbert, 1884, p. 51), in describing the fault scarps along the eastern base of the Sierra Nevada, that

one of them has been formed since the settlement of the country. It occurred in 1872, and produced one of the most notable earthquakes ever recorded in the United States. The height of the scarp varies from five to twenty feet, and its length is forty miles. Various tracts of land were sunk a number of feet below their previous positions, and one tract, several thousand acres in extent, was not only lowered, but carried bodily about fifteen feet northward.

Gilbert did not identify this tract, but if it is one of the fault-bounded depressions mapped by Willard D. Johnson (Hobbs, 1910) between Lone Pine and Diaz Lake and if Gilbert was describing horizontal movement relative to the Sierra Nevada, as seems to be implied, then the strike-slip movement was left lateral. The statement is ambiguous, however, and could be interpreted as implying northward movement relative to the area east of the sunken tract; that movement would require right-lateral strike slip. If the tract moved northward relative to the areas both east and west of it, the west bounding fault would be left lateral and the east bounding fault would be right lateral in strike-slip movement, but this movement is unlikely.

Holden (1898, p. 88-92) made a review of the Owens Valley earthquake of 1872 and reported a verbal account from Captain Keeler, after whom the town of Keeler was named, as follows:

A fissure was opened up in the earth from about 2 miles south of Lone Pine, extending 10 miles farther north. This fissure was 4 feet wide, and the ground on the east sank from 4 to 12 feet lower than that on the west side (or the west side was raised). At the same time the ground on the east was moved bodily 10 feet or so to the north (or the other side to the south), This was clearly shown by the position of fences running east and west.

Captain Keeler gave Holden a photograph showing the shifting of a fence at a point $11 / 2$ miles south of Lone Pine, but unfortunately this photograph was never published. Keeler clearly described left-lateral faulting, as related by Holden, and this faulting is probably the same faulting as that described by Gilbert. V. P. Gianella (written commun., 1958) recovered evidence for left-lateral offset of a fence line $1 \frac{1}{2}$ miles south of Lone Pine, and this offset is probably the same as that described and photographed by Keeler.

Finally, Hobbs (1910), basing his analysis on the work of Johnson without having visited Owens Valley, presented evidence that the strike-slip movement in the Lone Pine area was right lateral. A photograph taken 
STRUCTURAL GEOLOGY AND VOLCANISM, OWENS VALLEY, CALIF.

by Johnson and published by Hobbs showing apparent right-lateral offset of a row of trees seems to confirm this analysis. As a result, the conclusion of Hobbs has been given rather more weight by recent workers than the opposing conclusion of Whitney, Holden, and, seemingly, Gilbert.

Evidence for left-lateral movement and an inference of right-lateral movement as reported by Mayo (1941) have already been described, as has the visual evidence (supported by seismic-refraction data) of left-lateral movement on a road offset just south of Lone Pine.

Interpretations favoring both right-lateral and leftlateral strike-slip movement along the faults of Owens Valley are certainly permissible. On the basis of certain theoretical considerations to be discussed in the following sections, the interpretation that movement was left lateral is favored in this report, but the interpretation that movement was right lateral cannot be ruled out on the basis of the published record and recoverable field evidence. Perhaps both left- and right-lateral strikeslip movement actually happened. In any event, extremely large horizontal displacements are unlikely to have occurred. The strike-slip and dip-slip components were probably about the same.

\section{RELATION TO REgIONAL TECTONIC PATTERN}

The strike of the San Andreas fault as measured in a range in latitude defined by normals to the north and south limits of the Owens Valley region is $N .40^{\circ} \mathrm{W}$. The strike-slip movement along the San Andreas is known to be right lateral. However, the mean trend of Owens Valley is $\mathrm{N} .17^{\circ} \mathrm{W}$. (fig. 19); so, the acute angle between the San Andreas and Owens Valley is $23^{\circ}$. If the direction of the greatest principal (horizontal) stress in a region including both the San Andreas and Owens Valley is west of $\mathrm{N} .17^{\circ} \mathrm{W}$. but east of N. $40^{\circ} \mathrm{W}$., right-lateral movement on the San Andreas and leftlateral movement on the faults of Owens Valley are compatible. The so-called Walker Lane in western Nevada (fig. 20) is parallel to the San Andreas, and rightlateral offset along this zone has been inferred (Gianella and Callaghan, 1934; Longwell, 1950; Locke and others, 1940). Again, right-lateral movement on the faults of the Walker Lane and left-lateral movement on the faults of Owens Valley are compatible.

The Garlock fault south of Owens Valley (fig. 20) varies greatly in direction of strike. The Garlock is considered to be a left-lateral strike-slip fault. This movement is compatible with left-lateral strike-slip movement along the faults of Owens Valley and with a southward-moving Sierra block.

The Seismological Laboratory of the California Institute of Technology made a comprehensive study of the major Arvin-Tehachapi earthquake of 1952. (See Gutenberg, 1955; Richter, 1955; and Benioff, 1955.) The earthquake occurred along the White Wolf fault south of the Sierra Nevada and north of and roughly parallel to the Garlock fault (fig. 20). The strike of the White Wolf fault is about N. $50^{\circ}$ E., and its dip is $60^{\circ}-66^{\circ}$ southeast at the focal depth of the earthquake (about $15 \mathrm{~km}$ ), as Gutenberg (1955) showed. The southern block was thrust up with respect to the northern block, and the direction of strike slip was left lateral. The dip-slip component was determined to be about 1.4 times as great as the strike-slip component, based on analysis of the seismograms (Gutenberg, 1955). This determination agrees closely with the results of leveling and triangulation made before and after the earthquake by the U.S. Coast and Geodetic Survey (Whitten, 1955). The relative dip-slip and strike-slip components were both measured to be about 4 feet.

Scheidegger (1959), by a statistical analysis of the mechanisms of the aftershocks of the Arvin-Tehachapi earthquake, found the direction of tectonic motion to be N. $32^{\circ} \mathrm{W}$, or approximately normal to the strike of the White Wolf fault. This direction is in agreement with the direction obtained by Gutenberg (1955) in a faultplane solution on the main shock. The results of Scheidegger's analysis are compatible with a southward-moving Sierra Nevada block and left-lateral strike-slip movement along the faults of Owens Valley. They are also compatible with right-lateral movement along the San Andreas fault and the Walker Lane and with leftlateral movement along the Garlock.

Cordell Durrell (1950) mapped a fault having more than 3 miles of left-lateral strike-slip displacement near the Sierra Nevada front west of Blairsden. When this fault as described by Durrell (written communication, 1958) was plotted on a geologic map (fig. 20), it was found to strike within a few degrees of the mean trend of Owens Valley, suggesting that the main faults having similar strike along the eastern front of the Sierra Nevada, including those of Owens Valley, may be members of a system of en echelon left-lateral strike-slip faults.

Right-lateral strike-slip displacements on faults in the Death Valley area were proposed by Curry (1938) and by Noble and Wright.(1954). Hopper (1947) also presented evidence for right-lateral strike-slip displacements on faults of Panamint Valley. All these faults are oriented more northwesterly than is the trend of Owens Valley; therefore, they are compatible with leftlateral displacements on the faults of Owens Valley.

In the foregoing discussion, an attempt has been made to demonstrate compatibility of left-lateral strike- 


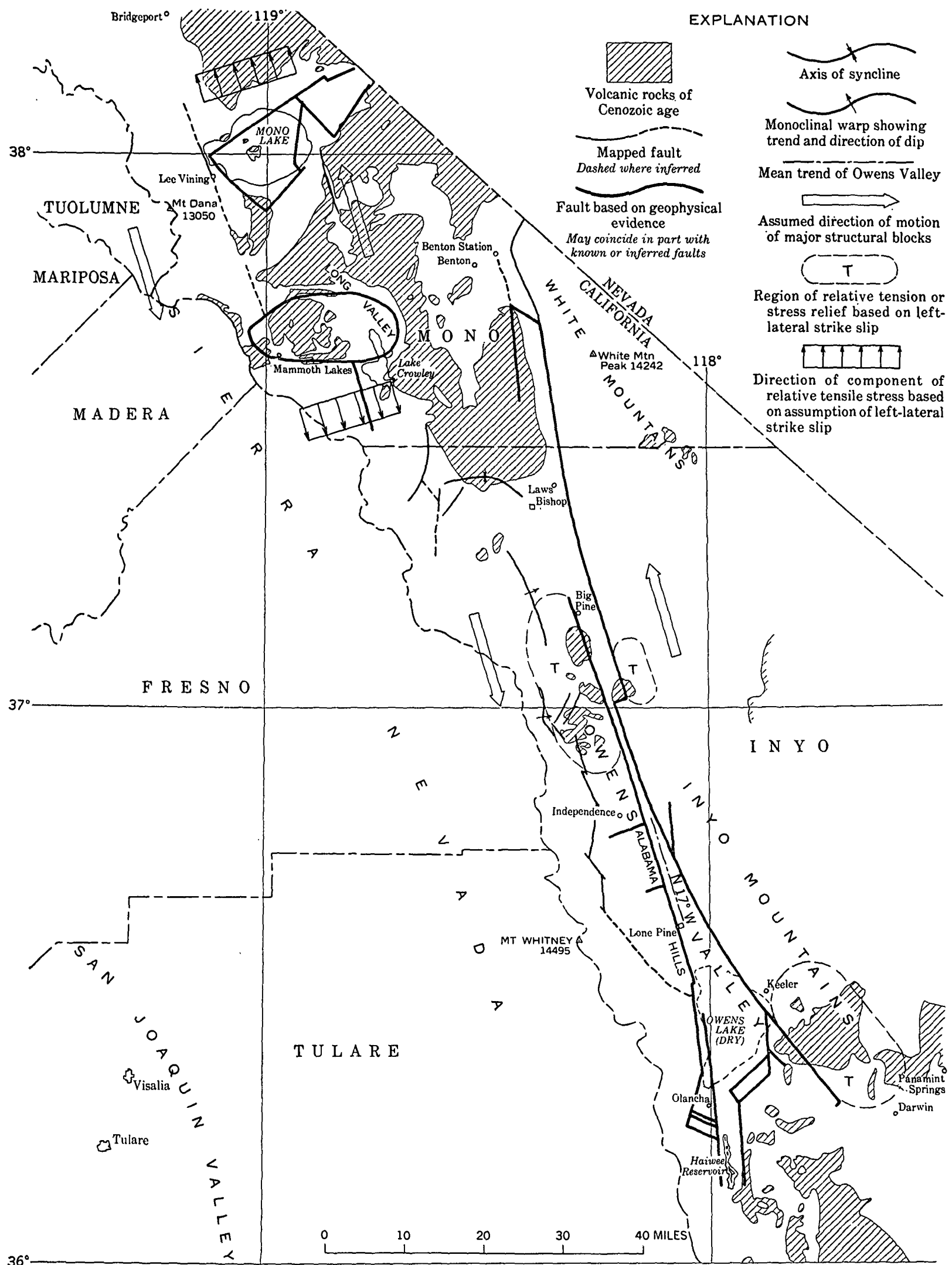

Fradre 19.-Map showing fault pattern and volcanic rocks of Cenozoic age of the Owens Valley region, inferred greatest princlpal (compressive) stresses, and inferred local relative tensile stresses. 


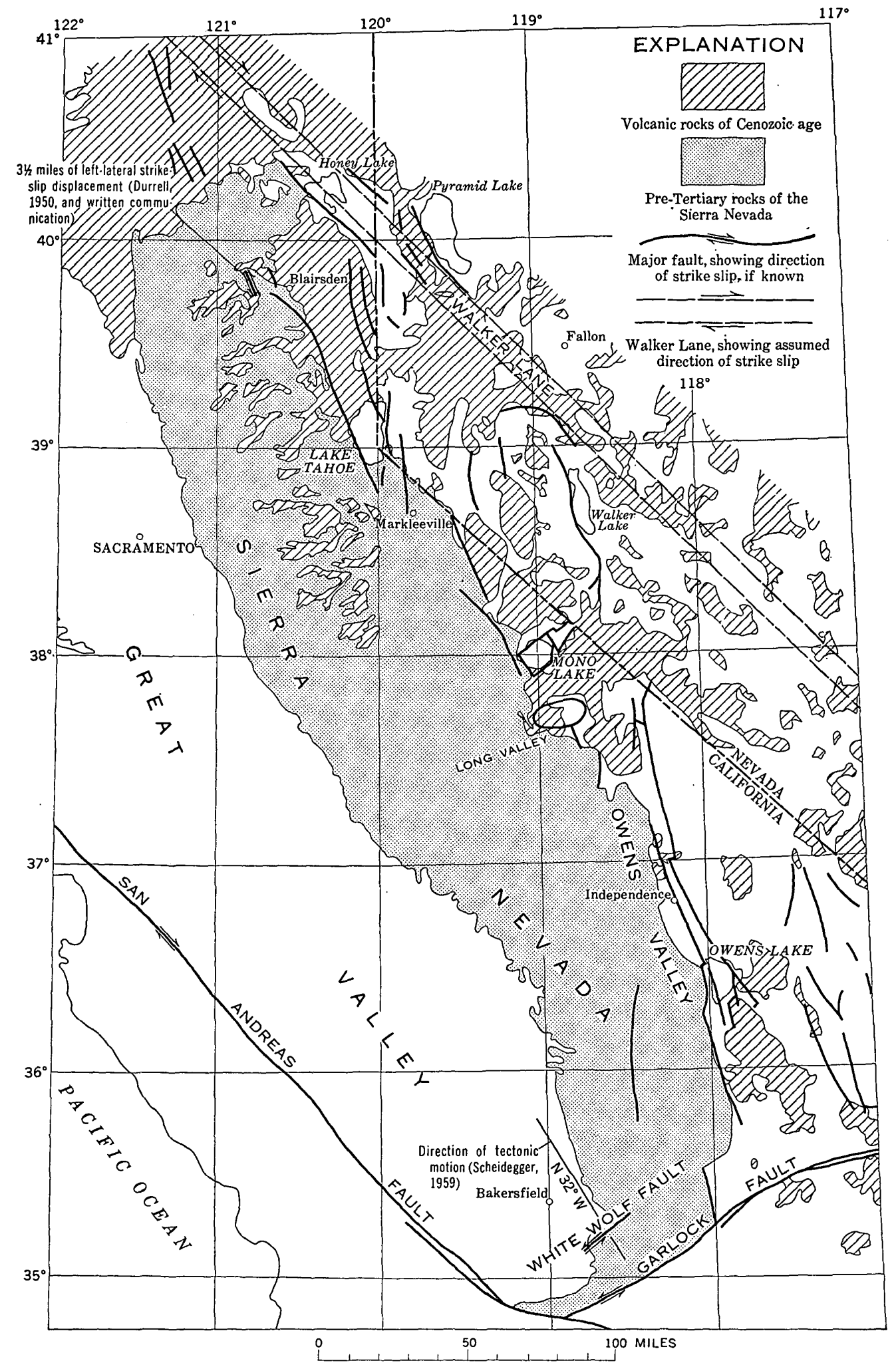

Frours 20.-Regional geology of southern California and southwestern Nevada showing faults and volcanic rocks. (Modified from the "Geologic Map of the United States," Stose, 1932, and the "Tectonic Map of the United States," Longwell, 1944.) 
slip displacements on the faults of Owens Valley with both right-lateral and left-lateral displacements on other major faults of southern California and western Nevada. An implicit assumption was made that the greatest principal stress has been horizontal and that it has been oriented somewhere between $\mathrm{N} .17^{\circ} \mathrm{W}$. and N. $40^{\circ} \mathrm{W}$. throughout the region discussed, and this assumption seems to be compatible with all available geologic and seismological evidence. However, no attempt has been made to apply the principles of shear in a homogeneous elastic medium (Anderson, 1951). As Benioff (1955, p. 203) pointed out:

The application of stress to a rock mass having a structural weakness such as a contact or other defect produces a fracture which doesn't necessarily follow the geometry of fractures in a homogeneous medium. Likewise, once a fracture has occurred, movements will continue on it even though the stress pattern is greatly altered from the original form which produced the fracture.

This remark is particularly appropriate to the Owens Valley region, which has contrasting rock types and structural weaknesses inherited from the Nevadan orogeny.

Owens Valley is probably a great left-lateral shear zone, and the Sierra Nevada has probably been moving south with respect to Owens Valley and the area farther east. Additional arguments supporting this conclusion have been presented by the senior author (Pakiser, 1960). However, the conclusion that no movement along the faults of Owens Valley has been right-lateral is not permissible.

\section{VOLCANISM OF OWENS VALLEY}

In Owens Valley, volcanic activity of Cenozoic age was largely confined to three areas near the ends of important faults (fig. 19). Mayo (1941, p. 1064) observed that fault movement between the granitic rocks of the Sierra Nevada and the sedimentary rocks farther east should open many channels for the extrusion of lava. It is therefore no surprise to find that volcanoes do occur along the Sierra Nevada front, but these eruptions are not evenly distributed along the base of the mountains ***. It is obvious that the volcanoes are clustered in certain favored areas.

In a previous paper, the senior author (Pakiser, 1960) showed that regions of local relative tension or stress relief near the ends of or discontinuities in faults could come about as a result of strike-slip displacements. Such regions of stress relief should favor the eruption of magma.

The displacement at both ends of a strike-slip fault must be zero, and at some unspecified distance from each of these ends, the displacement of one side relative to the other must be the full amount of horizontal movement. On one side near each end (the side on which, on a map, the displacement arrow points away from the end) the rocks will be extended, and a region of relative tension or stress relief will come into existence. On the opposite side near each end (the side on which, on a map, the displacement arrow points toward the end) the rocks will be effectively shortened, and a region of compression will result. These regions will be alternately disposed, and a region of stress relief and a region of compression will therefore exist on each side of the fault.

If two parallel faults with the same direction of strike-slip displacement are arranged en echelon and if they extend outward in opposite directions, either a region of stress relief or a region of compression will be formed between them, depending on whether the region between them tends to be extended or shortened. Volcanism would be favored if the region between the faults is a region of stress relief.

In the volcanic field near the south end of the Inyo Mountains (fig. 19) the volcanic eruptions took place on the east side and near the end of the bounding fault. A region of stress relief presumably existed in the area of these volcanic eruptions, and it may be inferred, therefore, that the Inyo Mountains moved north relative to Owens Valley and that the bounding fault is a leftlateral strike-slip fault.

The three vents (Mayo, 1941) for the small volcanic field that flowed out of the Inyo Mountains between Big Pine and Independence near the 37th parallel (fig. 19) are located on the east side of the easternmost bounding fault, and the bounding fault system consists of two offset segments in this area. The volcanic eruptions took place near and east of the end of the fault that continues northward to become the bounding fault of the White Mountains. Again, if the volcanic eruptions took place in a region of stress relief, the White Mountains and the Inyo Mountains may be inferred to have moved north relative to Owens Valley, and the bounding fault is a left-lateral strike-slip fault.

Examination of the outcrops of volcanic rock south of Big Pine and north of Independence shows that the volcanic area just south of Big Pine is near the end of a major fault that passes northward into the warp mapped by Bateman and confirmed by the geophysical evidence. A region of stress relief presumably existed on the west side of this fault near its northern end, and again, left-lateral movement on this fault, which is an extension of the fault east of Independence mapped by Knopf (1918) may be reasonably inferred. The fault continues south to join the earthquake fault of 1872 that bounds Alabama Hills near Lone Pine. All vents for the Big Pine volcanic field (Mayo, 1941) are located on 
the west side of the fault that terminates just north of Big Pine.

Thus the volcanic activity and the fault pattern in the area between Big Pine and Independence seem to suggest left-lateral movement. Owens Valley seems to be a great left-lateral shear zone. This shear zone suggests that the Sierra Nevada has been moving south with respect to Owens Valley and the area farther east.

If the Sierra Nevada has been moving south with respect to the area to the east, the area in the great offset of the Sierra Nevada front that contains Long Valley and Mono Basin (fig. 19) would tend to be stretched or pulled apart. The local component of relative tensile stress or stress relief that would be responsible for such a stretching or pulling apart would be parallel to the mean trend of Owens Valley (fig. 19). The Long Valley-Mono Basin area was the locus of the most intense and complex volcanism in the entire Owens Valley region. This area is still volcanically active, as is shown by the hot springs (Pakiser and others, 1960). The volcanic field in the embayment of the Sierra Nevada front east of Blairsden (fig. 20) seems to be similarly related to fault trends, and here left-lateral strike-slip displacements have been measured (Durrell, 1950).

The mechanism described does not seem to account for the volcanic rocks in the Coso Range or for those west of the Sierra Nevada crest (see, for example, Webb, 1950), but our geophysical investigations shed little light on the structural features in these places.

If Owens Valley is a great left-lateral shear zone, Alabama Hills may have been elevated along a series of east-trending reverse faults or as a result of compressive folding in response to local compressive stresses acting parallel to the valley. The main west fault bounding Owens Valley is sharply offset and changed in strike at the south end of Alabama Hills, and this discontinuity would cause compressive stresses to build up locally in Alabama Hills if the horizontal movement is left-lateral.

Some of the short faults that strike roughly normal to Owens Valley (for example, at the 37th parallel, south of Owens Lake) may also be reverse faults. Thus the deepest wedge of Owens Valley between Independence and the southern limit of Owens Lake could have been in part depressed in response to local compressive stresses.

Two independent lines of reasoning have led to the conclusion that Owens Valley is a left-lateral shear zone and that the Sierra Nevada has been moving south with respect to the Great Basin region to the east. This conclusion is compatible with the majority of the published accounts of the earthquake of 1872 and with the regional tectonic pattern of southern California and western Nevada. The strike-slip displacements needed to bring about volcanic eruptions by relief of stress are likely to be small; certainly, horizontal movements comparable to those along the San Andreas cannot have happened in the Owens Valley area. The strike-slip and dip-slip displacements in the Owens Valley region may have been about the same; at most, accumulative strike-slip displacements can hardly have exceeded a few miles. Cordell Durrell (written commun., 1958) inferred about 12 miles of left-lateral strike-slip displacement through a zone 4-6 miles wide in the area near Blairsden.

\section{ORIGIN OF MONO BASIN AND LONG VALLEY}

We now possess a large inventory of facts and inferences on which a theory for the origin of Mono Basin and Long Valley can be constructed (Pakiser and others, 1960). These may be summarized as follows:

1. Mono Basin and Long Valley are large structural depressions bounded by vertical or near-vertical faults that have subsided and have received accumulations of about $18,000 \pm 5,000$ feet of stream-transported sediments and volcanic deposits of Cenozoic age.

2. These structural depressions are roughly equidimensional horizontally, and their depths are a large fraction of their horizontal dimensions.

3. Of the approximately $675 \pm 150$ cubic miles of Cenozoic rocks in Mono Basin and Long Valley, a large fraction (perhaps two-thirds) is probably of direct or secondary volcanic origin, but some (perhaps onethird) is from pre-Tertiary rock sources and was transported into these two depressions by streams.

4. The Cenozoic rocks in Mono Basin and Long Valley are divided into two or more major units on the basis of increasing seismic velocity with depth. These major units are layered, as is revealed by seismic reflections in Mono Basin and the velocity boundaries found from seismic refractions, and are presumed to have been deposited at least in part by orderly processes of sedimentation and volcanism.

5. The subsidence of these structural basins has been continuous or repeatedly rejuvenated through an interval of late Tertiary (?) and Pleistocene time, and deposits near the surface have therefore been displaced by faulting relatively much less than those near the pre-Tertiary floor. The Recent deposits at the surface have not been displaced at all in most places, and as a consequence virtually no physiographic expression of the bounding faults of the structural basins occurs.

6. Volcanic rocks are intimately associated with these structural basins. 
7. The Sierra Nevada may be moving south with respect to the area to the east, and this movement would create local relative tensile stresses or stress relief in the embayment of the Sierra Nevada front that contains Mono Basin and Long Valley (fig. 19).

The unusually great depth of these structural basins, their roughly equidimensional outlines horizontally, and the volcanic activity associated with them make the mechanism of basin-and-range type block faulting usually assumed inadequate as an explanation for their origin. Mono Basin and Long Valley are therefore postulated to have subsided along their bounding faults as support was removed by extrusion of volcanic material from a magma chamber at depth.

The physical-chemical relations of the volcanic activity in Mono Basin and Long Valley are too complex to be explained fully on the basis of our present knowledge of the petrology and chemical composition of the volcanic rocks. However, we can attempt to explain the origin of Mono Basin and Long Valley in terms of kinematic concepts (that is, movement of magma and blocks of solid rock) without making any assumptions on the nature of the energy involved.

To make this explanation, the volcanic rocks of intermediate and more silicic composition are assumed to have been withdrawn from a magma chamber within the earth's crust. Consideration of the basalts (except for minor products of magmatic differentiation) is excluded from the explanation on the assumption that the basalts were withdrawn from a deeper source, probably in the upper mantle. The intermediate rocks and rhyolites considered are assumed to be less dense as volcanic rocks than were their original materials in the magma chamber before eruption. The mass of these materials before and after eruption must have remained constant; therefore, they expanded after eruption, and they are assumed to have spread over an area larger than that of the magma chamber from which they came. If this change is so, a net deficiency of mass resulted in and above the magma chamber, and this deficiency is expressed by a gravity minimum anomaly on the preeruption surface, such as those observed in Mono Basin and Long Valley.

The problem then becomes one of finding the volcanic rocks corresponding to the mass deficiency of the source area, of finding a possible tectonic mechanism for relieving the pressure confining the magma in its chamber, and of describing the possible relations between volcanic activity and subsidence of Mono Basin and Long Valley.

If the basin deposits of volcanic origin occupy a combined volume in Mono Basin and Long Valley of 400-
500 cubic miles, if the combined volume of the structures is $600-700$ cubic miles, and if all of the subsidence is assumed to have been caused by withdrawal of magma from a magma chamber or two magma chambers at depth, a simple computation shows that about 200-300 cubic miles of volcanic deposits must be found outside the basin structures. These numbers are not to be taken literally, but they do indicate the general magnitude of the volumes required.

About 200-300 cubic miles of volcanic material having intermediate and silicic composition can be found in the Mono Basin and Long Valley areas; the volcanic rocks include the older rhyolite and andesite on the east flank of the Benton Range, the andesite of Bald Mountain, the large volume of rhyolite of Glass Mountain and its surroundings, the Bishop tuff of Gilbert (1938), and the pumice and obsidion erupted from Mono Craters (pl. 1, sheet 1). 'The large volume of rhyolite piled above the general level near the center of Long Valley (pl. 1, sheet 1) can also be included. Most of these rocks are more intimately associated with Long Valley than with Mono Basin. This association suggests the possibility that a magma chamber extended under both structural basins and that both Mono Basin and Long Valley may have subsided in response to eruption of volcanic material from either of the structural basins. Subsidence may have followed eruption from separated magma chambers under each structural basin, however. The paths traveled by the magma may have extended some distance beyond the basins, perhaps by migration along a surrounding system of fissures, to the places from which the volcanic rocks were erupted.

If the Sierra Nevada has been moving south with respect to the area to the east, as has been inferred, the area containing Mono Basin and Long Valley would tend to be stretched or pulled apart (Pakiser, 1960). Presumably the confining pressure at the depth to the top of the magma chamber (perhaps $10 \mathrm{~km}$ ) would have been approximately the same as the lithostatic pressure-2,500-3,000 bars-or about the same as the partial pressure of water that could be dissolved in the magma at saturation. Reduction of the confining pressure by local relative tensile stresses acting in a direction parallel to the mean trend of Owens Valley may have reduced this pressure to such an extent that the internal pressure of expansion in the magma chamber (assumed to be much less than the normal lithostatic pressure) could have exceeded the least principal stress plus the (essentially negligible) tensile strength of the surrounding rocks and thus have brought on eruption. If the local relative tensile stresses were large enough, open fissures may have extended downward to great depths, possibly even to the magma chamber. 
The same mechanism of stress relief could, of course, also have facilitated the eruption of basalt from a deeper source and thus possibly offers an explanation for the widespread basalt in the area (pl. 1, sheet 1).

Another possible effect of the reduction of stress would be actually to bring about generation of the magma by reduction of the melting point of the rock. Reduction of the melting point could have been brought about by two effects of stress relief: the effect of the stress relief itself (Yoder, 1952; Uffen, 1959) and the inward migration of water from the surrounding rocks under high pressure into the low-pressure region in the Mono Basin and Long Valley area. This explanation of the generation of magma depends on the assumption that the rocks at the depth of the magma chamber normally contain water far below the saturation amount (Tuttle and Bowen, 1958). Raising the water content would thus have a powerful influence on lowering the melting point. Very possibly the temperature was raised at the same time by the conversion of mechanical energy to heat in this tectonically active region. The actual physical-chemical mechanism of eruption may have been similar to that proposed by Kennedy (1955).

We conclude, as did Williams (1941) about Mono Basin, that Mono Basin and Long Valley may be regarded as volcano-tectonic depressions that subsided along faults that may have been blocked out by the same tectonic forces that produced Basin-and-Range faulting in the area or that may have been inherited from the Nevadan orogeny. The vertical movement, however, was caused mainly by the force of gravity pulling the blocks down as support was removed from below (Pakiser and others, 1960).

Without more precise information than that available and that which forms the main body of this report, the foregoing discussion and many of those that precede it remain only plausible, however great their probability.

\section{SUMMARY OF TECTONICS AND VOLCANISM}

The main bounding faults of Owens Valley may be very steeply dipping to vertical transcurrent faults along which significant (but probably not large) lateral movements have taken place. The vertical movement has been large, but it may at least in part be a secondary effect of strike slip.

A simple experiment using a card with cuts representing faults can show that, for small horizontal displacements, the secondary vertical movement can be several times as great as the primary horizontal movement. If the horizontal movement along the main faults of Owens Valley was left lateral, the volcanic eruptions in Owens Valley and in the Mono Basin-Long Valley area can be accounted for by the local relative tensile stresses that would come about as a result of southward movement of the Sierra Nevada with respect to Owens Valley and the area farther east. Magma may have been generated by the melting of solid rocks in such regions of stress relief.

Thus, an internally consistent theory relating the tectonics of the Owens Valley region with the volcanism has been proposed. This theory, though consistent with all the known facts, lacks clear proof and must be thus regarded as only probable.

The uplift of the Sierra Nevada took place only in minor part along the faults that bound the deepest wedge of Owens Valley. This uplift was probably caused in large part by vertical forces resulting from compensation in excess of isostatic equilibrium, as has been proposed by Oliver (1956). (See also Pakiser, 1960.)

\section{SUMTMARY OF GEOLOGIC HISTORY OF OWENS VALLEY REGION}

In late Paleozoic or early Mesozoic times the region of the southern Sierra Nevada that includes Owens Valley became the site of intense compressive forces acting in a northeast and southwest direction. These compressive forces led to the formation of a geosyncline in which thick deposits of sediments and volcanic debris accumulated (Vening-Meinesz, 1957). As compressive forces continued, the sedimentary and volcanic rocks of the geosyncline were folded during the Nevadan orogeny of late Mesozoic (probably late Jurassic) time. Some early mafic forerunners of the Sierra Nevada batholith were intruded into the western foothills during and shortly after folding (Curtis and others, 1958). The sedimentary and volcanic rocks of the geosyncline were dynamothermally metamorphosed during the period of intense folding as a result of increased pressure and temperature (Durrell, 1941; Krauskopf, 1953; Macdonald, 1941). On continued deformation, the southern Sierra Nevada was intruded by a series of igneous masses that together make up the main bulk of the great Sierra Nevada batholith. Intense contact metamorphism resulted from the intrusion of the batholith. Most of the mass of the batholith was intruded in Late Cretaceous time (Curtis and others, 1958).

Following the intrusion of the batholith, the southern Sierra may have been left in a state of isostatic unbalance (Vening-Meinesz, 1957). The mass deficiency of the deep root of the Sierra Nevada may have been greater than that needed to compensate the mass excess of the Nevadan fold mountains. So post-orogenic forces of vertical uplift may have become effective, and these forces may have elevated the Sierra Nevada in a series of movements from a surface of low relief per- 
haps no more than 3,000 feet above sea level to its present great heights. The forces may still be active (Oliver, 1956).

The southern Sierra Nevada was probably relatively quiescent during early Tertiary time. Then, in late Miocene or early Pliocene time, the range underwent a major uplift and tilting that led to the formation of the mature valleys of the Kern, Merced, and other rivers of the region (Lawson, 1904; Matthes, 1930). Intense volcanic activity occurred along the crest of the Sierra Nevada and in the great Basin east of the Sierra Nevada during this late Miocene or early Pliocene period of uplift. A period of quiescence followed during the early Pliocene, and the mature valleys were eroded. Some volcanic activity continued. In late Pliocene and early Pleistocene times, the southern Sierra Nevada was uplifted several thousand feet to its present great heights (Matthes, 1930). The youthful canyons of the Kern, Merced, and other rivers of the region were cut by newly invigorated streams after this uplift. Widespread volcanism along the Sierra Nevada crest and in the Great Basin accompanied and followed this uplift.

The faults of Owens Valley may have been inherited from zones of weakness brought into existence during the Nevadan orogeny (Mayo, 1941). Movement along these faults may have started in the early Tertiary, and significant faulting probably occurred in the Owens Valley region during the late Miocene and early Pliocene uplift of the Sierra Nevada (Matthes, 1930). The main faulting that created the great eastern escarpment of the Sierra Nevada, however, came in late Pliocene and early Pleistocene times after a period of quiescence during the early Pliocene (Matthes, 1930). Fault movements, involving both dip slip and strike slip, were still continuing as late as 1872 (Whitney, 1872), and the forces that caused them are probably still active. Richter (1959) is studying a series of earthquake shocks in southern Owens Valley that began in January 1959.

The Owens Valley shear zone existed probably before the late Pliocene and early Pleistocene uplift of the Sierra Nevada, and Owens Valley may have begun to subside and receive sediments at some earlier time. The subsidence of Mono Basin and Long Valley is postulated to have begun probably with the earliest Pliocene(?) volcanic activity in that area (Gilbert, 1941) and to have ended with the latest explosions from Mono Craters (Evernden and others, 1959) after the final (Tioga) Pleistocene glaciation. Because the Basin Ranges of the Mono Basin-Long Valley area are known not to have been blocked out by faults before late Pliocene or early Pleistocene time (Gilbert, 1941), the sub- sidence of Mono Basin and Long Valley seemingly began before the elevation of these ranges. Perhaps the subsidence of these structures was initiated synchronously with an early Pliocene(?) uplift of the Sierra Nevada.

Finally, four stages of glaciation (Blackwelder, 1931) sculptured the eastern slopes of the southern Sierra Nevada and built up impressive moraines; subsequently, in Recent time, Owens Valley has been modified by streams.

\section{LITERATURE CITED}

Anderson, E. M., 1951, The dynamics of faulting, $2 d$ ed.: Edinburgh, Oliver and Boyd, $206 \mathrm{p}$.

Anderson, G. H., 1937, Granitization, albitization, and related phenomena in the northern Inyo Range of CaliforniaNevada: Geol. Soc. America Bull., v. 48, no 1, p. 1-74.

Axelrod, D. I., 1957, Late Tertiary floras and the Sierra Nevadan uplift: Geol. Soc. America Bull., v. 68, no. 1, p. $19-46$.

Bailey, H. P., 1954, Climate, vegetation, and land use in southern California, in chap. 1 of Jahns, R. H., ed. : p. 31-44.

Baker, C. L., 1912, Physiography and structure of the western El Paso Range and the southern Sierra Nevada: California Univ. Pub. Geol. Sci. Bull., v. 7, no. 6, p. 117-142.

Barthelemes, A. J., 1946, Application of continuous profiling to refraction shooting: Geophysics, v. 11, no. 1, p. 24-42.

Bateman, P. C., 1956, Economic geology of the Bishop tungsten district, California: California Div. Mines Spec. Rept. $47,87 \mathrm{p}$.

Bateman, P. C., and Irwin, W. P., 1954, Tungsten in southeastern California, in chap. 8 of Jahns, R. H., ed.: p. 31-40.

Bateman, P. C., and Merriam, C. W., 1954, Geologic map of the Owens Valley region, California, Map Sheet 11, in Jahns, R. H., ed.

Benioff, Hugo, 1955, Relation of the White Wolf fault to the regional tectonic pattern, in Oakeshott, G. B., ed.: p. 203-204.

Birch, A. F., 1952, Elasticity and constitution of the earth's interior: Jour. Geophys. Research, v. 57, no. 2, p. 227-286.

Birch, A. F., Schairer, J. F., and Spicer, H. C., eds., 1942, Handbook of physical constants: Geol. Soc. America Spec. Paper $36,325 \mathrm{p}$.

Blackwelder, Eliot, 1931, Pleistocene glaciation in the Sierra Nevada and Basin Ranges: Geol. Soc. America Bull., v. 42 , no. 4. p. $865-922$.

Carlisle, Donald, Davis, D. L., Kildale, M. B., and Stewart, R. M., 1954, Base metal and iron deposits of southern California, in chap. 8 of Jahns, R. H., ed.: p. 41-50.

Chelikowsky, J. R., 1940, Tectonics of the rhyolite in the Mammoth embayment, California: Jour. Geology, v. 48 no. 4, p. 421-435.

Curry, H. D., 1938, Strike-slip faulting in Death Valley, California [abs.]: Geol. Soc. America Bull., v. 49, no. 12, pt. 2 , p. 1874-1875.

Curtis, G. H., Evernden, J. F., and Lipson, J. I., 1958, Age determination of some granitic rocks in California by the potassium-argon method: California Div. Mines Spec. Rept. 54, 16 p.

Dobrin, M. B., 1952, Introduction to geophysical prospecting, 1st ed. : New York, McGraw-Hill Book Co., 435 p.

Duerksen, J. A., 1949, Pendulum gravity data in the United States: U.S. Coast and Geod. Survey Spec. Pub. 244, 218 p. 
Durrell, Cordell, 1941, Metamorphism in the southern Sierra Nevada northeast of Visalia, California: California Univ. Pub. Geol. Sci. Bull., v. 25, no. 1, p. 1-117.

1950, Strike-slip faulting in the eastern Sierra Nevada near Blairsden, California [abs.] : Geol. Soc. America Bull., v. 61 , no. 12 , pt. 2 , p. 1522 .

Erwin, H. D., 1934, Geology and mineral resources of northeastern Madera County, California : California Jour. Mines and Geology, v. 30, no. 1, p. 7-78.

Evernden, J. F., Kistler, R., and Curtis, G. H., 1959, Cenozoic time scale of the West Coast [abs.]: Geol. Soc. America Bull., v. 70, no. 12, pt. 2, p. 1718.

Ewing, Maurice, and Press, Frank, 1959, Determination of crustal structure from phase velocity of Rayleigh wavesThe United States: Geol. Soc. America Bull., v. 70, no. 3, p. 229-244.

Gale, H. S., 1915, Salines in the Owens, Searles, and Panamint basins, southeastern California: U.S. Geol. Survey Bull. 580-L, p. 251-323.

Gianella, V. P., 1959, Left-lateral faulting in Owens Valley, California [abs.]: Geol. Soc. America Bull., v. 70, no. 12, pt. 2, p. 1721.

Gianella, V. P., and Callaghan, Eugene, 1934, The earthquake of December 20, 1932, at Cedar Mountain, Nevada, and its bearing on the genesis of Basin Range structure: Jour. Geology, v. 42, no. 1, p. 1-22.

Gilbert, C. M., 1938, Welded tuff in eastern California: Geol. Soc. America Bull., v. 49, no. 12, pt. 1, p. 1829-1862.

- 1941, Late Tertiary geology southeast of Mono Lake, California : Geol. Soc. America Bull., v. 52, no. 6, p. 781-815.

Gilbert, G. K., 1875, Report on the geology of portions of Nevada, Utah, California, and Arizona, surveyed in the years 1871 and 1872: Geog. Geol. Survey West of the 100th Meridian, v. 3, p. 17-187.

- 1884, A theory of the earthquakes of the Great Basin with a practical application: Am. Jour. Sci., 3d ser., v. 27, p. 49-53.

Gutenberg, Beno, 1955, The first motion in longitudinal and transverse waves of the main shock and the direction of slip, in pt. 2 of Oakeshott, G. B., ed.; p. 165-170.

Gutenberg, Beno, Wood, H. O., and Buwalda, J. P., 1932, Experiments testing seismographic methods for determining crustal structure: Seismol. Soc. America Bull., v. 22, no. 3, p. 185-246.

Heiland, C. A., 1940, Geophysical exploration : New York, Prentice-Hall, $1013 \mathrm{p}$.

Hinds, N. E. A., 1956, Late Cenozoic history of the Sierra Nevada, California-Nevada [abs.] : Geol. Soc. America Bull., จ. 67 , no. 12 , pt. 2 , p. 1796.

Hobbs, W. H., 1910, The earthquake of 1872 in the Owens Valley, California : Beitr. Geophys., v. 10, p. 352-385.

Holden, E. S., 1898, A catalogue of earthquakes on the Pacific coast, 1769 to 1897 : Smithsonian Inst. Misc. Colln. 1087, $253 \mathrm{p}$.

Hopper, R. H., 1947, Geologic section from the Sierra Nevada to Death Valley, California: Geol. Soc. America Bull., v. 58 , no. 5, p. 393-432.

Hubbert, M. K., 1948, A line integral method of computing the gravimetric effects of two-dimensional masses: Geophysics, v. 13, p. 215-225.

Hudson, F. S. 1955, Measurement of the deformation of the Sierra Nevada, California, since middle Eocene: Geol. Soc. America Bull., v. 66, no. 7, p. 835-870.

Jahns, R. H., ed., 1954, Geology of southern California : California Div. Mines Bull. 170.
Jahns, R. H., 1954, Investigations and problems of southern California geology, pt. 1 in chap. 1 of Jahns, R. H. ed.: p. 5-29.

Jennings, C. W., 1958, Geologic map of California, Death Valley Sheet: California Div. Mines.

Jennings, C. W., and Strand, R.G., compilers, 1958, Geologic map of California, Santa Cruz sheet: California Div. Mines.

Kane, M. F., and Pakiser, L. C., 1961, Geophysical study of subsurface structure in southern Owens Valley, California: Geophysics, v. 26, no. 1, p. 12-26.

Kennedy, G. C., 1955, Some aspects of the role of water in rock melts, in Poldervaart, Arie, ed., Crust of the earth-a symposium: Geol. Soc. America Spec. Paper 62, p. 489-503.

King, Clarence, 1878, Systematic geology: U.S. Geol. Explor. 40th Parallel Rept., v. 1, 803 p.

Knopf, Adolph, 1918, A geologic reconnaissance of the Inyo Range and the eastern slope of the southern Sierra Nevada, California: U.S. Geol. Survey Prof. Paper 110, 130 p.

Krauskopf, K. B., 1953, Tungsten deposits of Madera, Fresno, and Tulare Counties, California : California Div. Mines Spec. Rept. 35, 83 p.

Lachenbruch, A. H., 1957, Three-dimensional heat conduction in permafrost beneath heated buildings: U.S. Geol. Survey Bull. 1052-B, p. 51-69.

Larsen, E. S. Jr., Gottfried, David, Jaffe, Howard, and Waring, C. L., 1954, Age of the southern California, Sierra Nevada, and Idaho batholiths [abs.] : Geol. Soc. America Bull., v. 65, no. 12, pt. 2, p. 1277.

Lawson, A. C., 1904, The geomorphogeny of the upper Kern Basin: California Univ. Pub. Geol. Sci. Bull., v. 3, no. 15, p. 291-376.

Lee, C. H., 1912, An intensive study of the water resources of a part of Owens Valley, California: U.S. Geol. Survey Water-Supply Paper 294, 135 p.

Lee, W. T., 1906, Geology and water resources of Owens Valley, California: U.S. Geol. Survey Water-Supply Paper 181, 28 p.

Lindgren, Waldemar, 1911, The Tertiary gravels of the Sierra Nevada of California: U.S. Geol. Survey Prof. Paper 73, $226 \mathrm{p}$.

Locke, Augustus, Billingsley, P. R., and Mayo, E. B., 1940, Sierra Nevada tectonic patterns: Geol. Soc. America Bull., v. 51, no. 4, p. 513-539.

Longwell, C. R., chm., 1944, Tectonic map of the United States: Am. Assoc. Petroleum Geologists Bull., v. 28, no. 12, p 1767-1774.

- 1950, Tectonic theory viewed from the Basin Ranges: Geol. Soc. America Bull., v. 61, no. 5, p. 413-433.

Mabey, D. R., 1958, Gravity study of the Death Valley region, California [abs.]: Geol. Soc. America Bull., v. 69, no. 12, pt. 2, p. 1695.

Macdonald, G. A., 1941, Geology of the western Sierra Nevada between the Kings and San Joaquin Rivers, California: California Univ. Pub. Geol. Sci. Bull., v. 26, no. 2, p. 215-286.

Mason, B. H., 1952, Principles of geochemistry : New York, John Wiley \& Sons, 176 p.

Matthes, F. E., 1930, Geologic history of the Yosemite Valley: U.S. Geol. Survey Prof. Paper 160, 137 p.

1933, Geography and geology of the Sierra Nevada, in Internat. Geol. Cong. Guidebook 16th, Excursion C-1, Middle California and Western Nevada : p. 26-40

1947, A geologist's view, in Peattie, Roderick, ed., The Sierra Nevada, the range of light: New York, Vanguard Press, p. 166-214. 
Mayo, E. B., 1931, Fossils from the eastern flank of the Sierra Nevada, California: Sclence, new ser., v. 74, no. 1925, p. 514-515.

1934, The Pleistocene Long Valley Lake in Eastern California : Science, new ser., v. 80, no. 2065, p. 95-96.

1937, Sierra Nevada pluton and crustal movement: Jour. Geology, v. 45, no. 2, p. 169-192.

1941, Deformation in the interval Mt. Lyell-Mt. Whitney, California: Geol. Soc. America Bull., v. 52, no. 7, p. 10011084.

1947, Structure plan of the southern Sierra Nevada, California: Geol. Soc. America Bull., v. 58,, no. 6, p. 495-504.

Miller, W. J., 1928, Geology of Deep Spring Valley, California : Jour. Geology, v. 36, no. 6, p. 510-528.

Mumford, R. W., 1954, Deposits of saline minerals in southern California, in chap. 8 of Jahns, R. H., ed. : p. 15-22.

Nettleton, L. L., 1940, Geophysical prospecting for oil, 1st ed.: New York, McGraw-Hill Book Co., 444 p.

Noble, L. F., and Wright, L. A., 1954, Geology of the central and southern Death Valley region, California, in chap. 2 of Jahns, R. H., ed.: p. 143-160.

Nolan, T. B., 1943, The Basin and Range province in Utah, Nevada, and California: U.S. Geol. Survey Prof. Paper 197-D, p. 141-196.

Oakeshott, G. B., ed., 1955, Earthquakes in Kern County, California, during 1952: Oalifornia Div. Mines Bull. 171.

Oliver, H. W., 1956, Isostatic compensation for the Sierra Nevada California [abs.]: Geol. Soc. America Bull., v. 67, no. 12, pt. 2, p. 1724.

Pakiser, L. C., 1960, Transcurrent faulting and volcanism in Owens Valley, California : Geol. Soc. America Bull., v. 71, no. 2, p. 153-159.

Pakiser, L. C., Jr., and Black, R. A., 1957, Exploring for ancient channels with the refraction seismograph [Arizona-Utah]: Geophysics, v. 22, no. 1, p. 32-47.

Pakiser, L. C., Jr., Mabey, D. R., and Warrick, R. E., 1954, Mapping shallow horizons with reflection seismograph [Oklahoma-Kansas] : Am. Assoc. Petroleum Geologists Bull., v. 38 , no. 11, p. 2382-2394.

Pakiser, L. C., Press, Frank, and Kane, M. F., 1960, Geophysical investigation of Mono Basin, California : Geol. Soc. America Bull., v. 71, no. 4, p. 415-447.

Press, Frank, 1956, Determination of crustal structure from phase velocity of Rayleigh waves, Part 1-Southern California : Geol. Soc. America Bull., v. 67, no. 12, pt. 1, p. 16471658.

Putnam, W. C., 1949, Quaternary geology of the June Lake district, California: Geol. Soc. America Bull., v. 60, no. 8, p. 1281-1302.

Richter, C. F., 1955, Seismic history in the San Joaquin Valley [art. 3], and Foreshocks and aftershocks [art. 9] in pt. 2 of Oakeshott, G. B., ed. : p. 177-197.

1958, Elementary seismology: San Francisco, Calif., W. H. Freeman \& Co., 768 p.

1959, Current studies of minor earthquakes [abs.]: Geol. Soc. America Bull., r. 70, no. 12, pt. 2, p. 1743.

Rinehart, C. D., and Ross, D. C., 1957, Geology of the Casa Diablo Mountain quadrangle, California : U.S. Geol. Survey Geol. Quad. Map GQ-99.

Rinehart, O. D., Ross, D. C., and Huber, N. K., 1959, Paleozoic and Mesozoic fossils in a thick stratigraphic section in the eastern Sierra Nevada, California : Geol. Soc. America Bull., v. 70, no. 7, p. $941-945$.
Russell, I. C., 1887, Notes on the faults of the Great Basin and of the eastern base of the Sierra Nevada: Philos. Soc. Washington Bull., v. 9, p. 5-8.

Scheidegger, A. E., 1959, Note on the tectonics of Kern County, California, as evidenced by the 1952 earthquakes: Jour. Geophys. Research, v. 64, no. 10, p. 1499-1501.

Schultz, J. R., 1937, A late Cenozoic vertebrate fauna from the Coso Mountains, Inyo Canyon, California: Carnegie Inst. Washington Pub. 487, p. 75-109.

Skeels, D. C., 1947, Ambiguity in gravity interpretation: Geophysics, v. 12, no. 1, p. 43-56.

Smith, G. I., and Pratt, W. P., 1957, Core Logs from Owens, China, Searles, and Panamint basins, California : U.S. Geol. Survey Bull. 1045-A, p. 1-62.

Stose, G. W., 1932, Geologic map of the United States: U.S. Geol. Survey.

Swick, C. H., 1942, Pendulum gravity measurements and isostatic reductions: U.S. Coast and Geod. Survey Spec. Pub. $232,82 \mathrm{p}$.

Thompson, G. A., and Sandberg, C. H., 1958, Structural significance of gravity surveys in the Virginia City-Mount Rose area, Nevada and California: Geol. Soc. America Bull., v. 69 , no. 10, p. $1269-1281$.

Tuttle, O. F., and Bowen, N. L., 1958, Origin of granite in the light of experimental studies in the system $\mathrm{NaAlSi}_{3} \mathrm{O}_{8}$ $\mathrm{KAlSi}_{3} \mathrm{O}_{8}-\mathrm{SiO}_{3}-\mathrm{H}_{2} \mathrm{O}$ : Geol. Soc. America Mem. 74, $153 \mathrm{p}$.

Uffen, R. J., 1959, On the origin of rock magma: Jour. Geophys. Research, v. 64, no. 1, p. 117-122.

Vacquier, Victor, Steenland, N. C., Henderson, R. G., and Zietz, Isidore, 1951, Interpretation of aeromagnetic maps: Geol. Soc. America Mem. 47, $151 \mathrm{p}$.

Vening-Meinesz, F. A., 1957, The geophysical history of a geosyncline: Royal Netherlands Acad. Sci. Proc., ser. B., v. 60, no. 2, p. 126-140.

Walcott, C. D., 1897, The post-Pleistocene elevation of the Inyo Range, and the lake beds of Waucobi embayment, Inyo County, California : Jour. Geology, v. 5, no. 4, p. 340-348.

Webb, R. W., 1946, Geomorphology of the middle Kern River Basin, southern Sierra Nevada, California: Geol. Soc. America Bull., v. 57, no. 4, p. 355-382. 1950, Volcanic geology of Toowa Valley, southern Sierra Nevada, California: Geol. Soc. America Bull., v. 61, no. 4, p. 349-357.

Whitney, J. D., 1865, Geology of the Sierra Nevada : California Geol. Survey, v. 1, pt. 2, p. 199-497.

1872, The Owens Valley earthquake: Overland Monthly, v. 9, p. 130-140, 266-278.

Whitten. C. A., 1955, Measurements of earth movements in California, in Oakeshott, G. B., ed.: p. 75-80.

Williams, Howel, 1941, Calderas and their origin: California Univ. Pub. Geol. Sci. Bull., v. 25, no. 6, p. 239-346.

Woollard, G. P., 1958, Results for a gravity control network at airports in the United States: Geophysics, v. 23, p. 520-535.

Worzel, J. L., and Shurbet, G. L., 1955, Gravity interpretations from standard oceanic and continental crustal sections, in Poldervaart, Arie, ed., Crust of the earth-a symposium: Geol. Soc. America Spec. Paper 62, p. 87-100.

Wright, L. A., Chesterman, C. W., and Norman, L. A., Jr., 1954, Occurrence and use of nonmetallic commodities in southern California, in chap. 8 of Jahns, R. H., ed.: p. 59-74.

Yoder, H. S., Jr., 1952, Change of melting point of diopside with pressure: Jour. Geology, v. 60, no. 4 p. 364-374. 
$<$ 


\section{INDEX}

[Italio page numbers indicate mafor references]

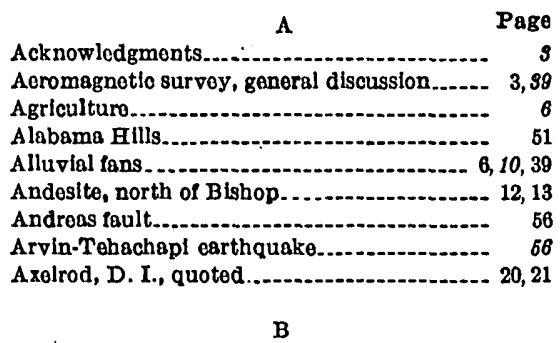

Basln and Range structural features, general discussion Sec also particular feature.

Basalt, donsity of....

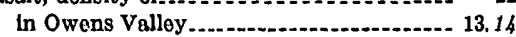

magnetic susceptibility of................ $\$ 9$

north of Bishop............................ 12, 13

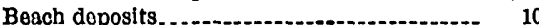

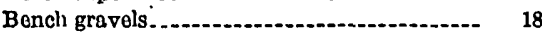

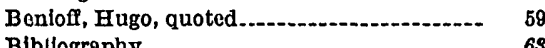

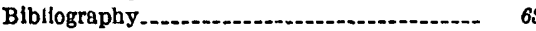

Big Pine volcanic fleld...................... 59

Blshop tuff............................... 19, 22, 27, 50

Blackwelder, Ellot, quoted...................... 11

Brachiopods

Brines

Brosd Volloy stago

Calderas .................................... 17

Camplto sandstone................................. 8

Canyon stage

Canyon-cutting stages. See particular stage.

Casa Diablo Mountain pluton................. 40,42

Conozolc rocks, density of..................... 28

general discussion . ........................ 9,62

in Long Valley.......................... 58

in Owons Valley.............

soismic volocity in

volume of

Corro Cordo mine

Chemo Plateou 20

Chainman shale.

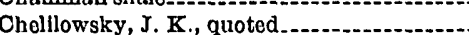

Clay

Olimate.

Coso formation.

Coyoto warp. ........... 15

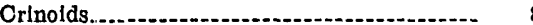

Crust, thlckness of ....................... 29

Deadman Creok.

Deep Spring formation.

Donity of rocks,

Diatoms

Dlaz Lake beds..........

Dikes................................................... 15, 42

Diorltic plutonic rocks, magnetic susceptl-

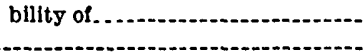

E Page

$6,16,29,55,56$

Economic development..........................

Ely Springs dolomite

En echelon faults

Erosion surfaces, general discussion

See also particular surface or 20

Esmeralda formation..

Eureks quartzite

Evolution of land forms, general discussion. paleobotanic evidence for

physiographic evidence for

\section{$\mathbf{F}$}

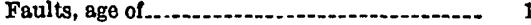

Basin and Range

dip-slip. 54

evidence for . . .

ground-water barriers formed by............ 45

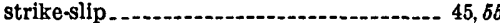

Fault scarps.................................. 15, 16

Fleld party, personnel.........................

Fieldwork

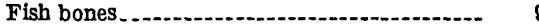

Florg, fossil....................... 20

Fossils......................... 8, 8,20

Garlock fault

Gastropods

Geography, general discussion -

Geologic history, summary of...................

Geophysical surveys, general discussion......

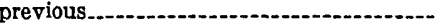

See also particular type of surtey.

Gianella, V. P., quoted

Gilbert, G. K., quoted................

Glacial deposits . ............................... 11

Glacial moraines.................... 6, $11,13,20,51,53$

Glacier

Gold...

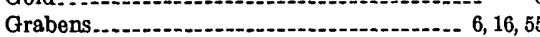

Granitoid rocks, general discussion............ 8

Gravity contour maps, general discussion....

Gravity meters used, list of .....................

Gravity profle $A-A^{\prime \prime \prime}$

$B-B^{\prime \prime}$

(10.--

$C-C^{\prime}$

$D-D^{\prime}$

$F-F^{\prime}$

$\theta-G^{\prime}$

Gravity survev, accuracy of data............. fleldwork and computations..............-

general discussion . ......................... 3,28

interpretation of data....................

Ground-water barriers, faults acting as....... 45

H

Drainage
Hanging valleys

Hanging valleys._-_- 19
Page

High Valley zone

18,19

Hilton Creek fault

Hinds, N. E. A., quoted.

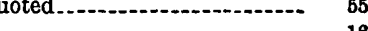

(6)

\section{I}

International Ellipsoid nvestigations, present. . previous..

purpose of.

Isostatic compensation............

3

Jahns, R. H., quoted

Kern Canyon fault. .........

Kinematic processes, listed

King, Clarence, quoted........................... 6

Knopi, Adolph, quoted............... 2, 10, 16, 19

I

Lake beds, general discussion............. 6, 22, 52, 53 older. younger...

Younger.

Land forms. See particular land form and Evolution of land forms.

Latite.

Lead deposits

Lindgren, Waldemar, quoted

Locke, Augustus, quoted

Long Valley, Cenozoic rocks in............... 58 magnetic high in ......................... 40, 41 origin of structural geology of

Los Angeles Aqueduct.

Lost Burro formation.

$\mathbf{M}$

Magnetic anomalies, analysis of

Magnetic contour map, general discussion.-.

Magnetic properties of rock, general survey.

Mayo, $\mathrm{E}$. B quoted

McGee glacial stage............................. 11

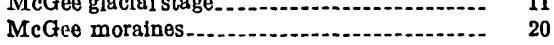

McGee tills

Mehrten formation........................... 18, 20

Metamorphic rocks, density of . ............... 22 general discussion

Mineral production. See Economic Develment.

Mono Basln, gravity anomaly................ 26

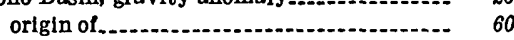
structural geology of

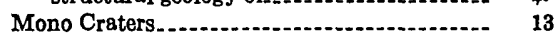

Mountain Valley stage......................... 19, 20

Mudflows 
Page

Older structural framework, general discus.

Olivine basalt. See Basalt.

Ostracodes -

Owens Lake Basin, gravity survey of.........

Owens Valley, area deflned

area north of, gravity survey of..........

Cenozoic rocks in.

central, gravity survey of........................

faulting in.

northern, gravity survey of

structural geology of

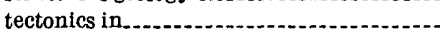

volcanism in

Panamint Valley................................

Paoha Island

Perlite.

Physiography, general discussion.........

Pine Creek mine

Plutonic rocks, density of........................

Pogonip group

Poverty Hills....................................

Pre-Tertiary rocks, density of

depth to

general discussion

gra vity affected by

seismic velocity in

$\mathbf{R}$

Rayleigh waves.......

Reed dolomite...

Regional gravity
Page

Rhyolite, north of Bishop................ 11, 12, 13 in Owens Valley........................ 14

Ricardo erosion surface..................-...-..- 20

Ricardo formation................. 14

Scheelite

Sedimentary rocks, White and Inyo Mountains, general discussion.

Seismic profile, analysis of

$1 .$.

2 (a)

3

4 -

$6-1--10-0$

Seismic-refraction measurements

Seismic survey, field methods

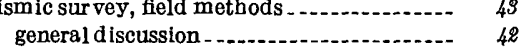

interpretation of data

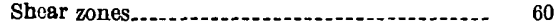

Sherwin glacial stage . ...................... 9, 11, 13

Sierra Nevada batholith...................... 8

Silicic plutonic rocks, magnetic susceptibility of.

Silver deposits.

Silver Peak group.............................. 8

Stream deposits........................... 52,45

Structural geology, general discussion......... 48 regional tectonic pattern related .......... $\quad 56$

Subsummit Plateau........................... 18

Sumatra, Pilomasin Basin of ................. 17

Summit Upland............................ 18, 19

Structural trends.............................. 14

Synclines

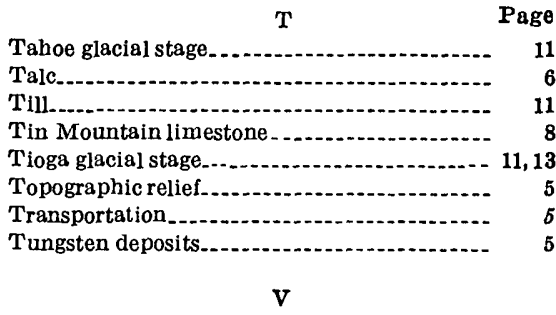

Valley Springs formation.

Vegetation

Veins

Volcanic necks................................ 40, 41, 42

Volcanic pile.........................................

Volcanic pipes..................................... 12

Volcanic rocks, magnetic susceptibility of.... north of Bishop, general discussion....... 11

Owens Valley, geners] discussion..........

Pleistocene, general discussion............. 19

Tertiary(?) age, general discussion........- 11

Volcanic vents................................. 12

Volcanism, in Owens Valley..................... 11, 59

Volcano-tectonic features, general discussion.- 17

\section{W}

Walker Lane.

Waucobe Canyon la

Weathered layer, seismic velocities in..........

Webb, R. W., quoted.

White Wolf fault.

Whitnoy, J. D., quoted $\mathrm{z}$

Zinc deposits 